In cooperation with the San Antonio Water System

Geologic, Hydrologic, and Geochemical Identification of Flow Paths in the Edwards Aquifer, Northeastern Bexar and Southern Comal Counties, Texas

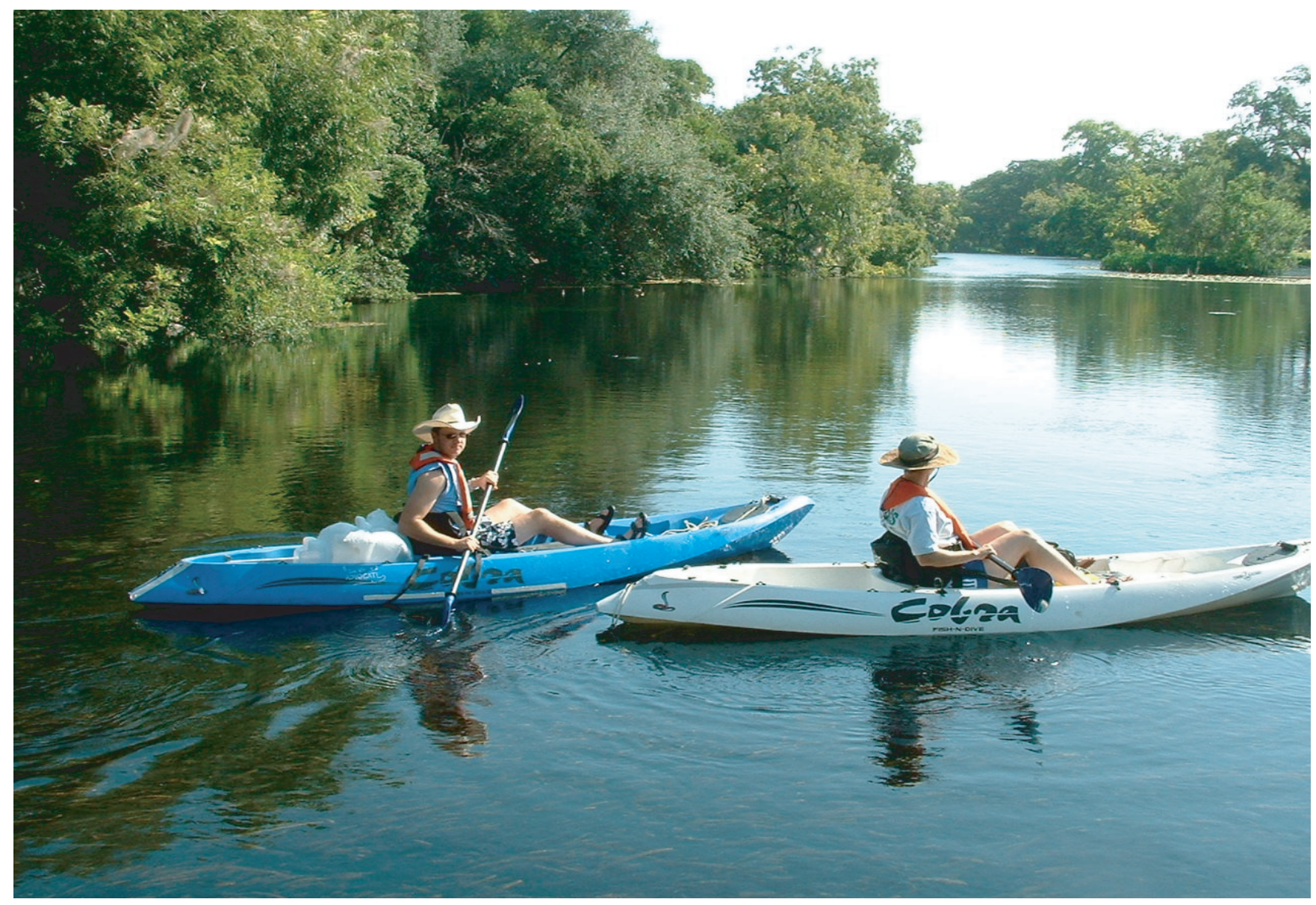

Scientific Investigations Report 2007-5285 
Cover: U.S. Geological Survey hydrologic technicians preparing to collect samples on Landa Lake, New Braunfels, Texas. 


\section{Geologic, Hydrologic, and Geochemical Identification of Flow Paths in the Edwards Aquifer, Northeastern Bexar and Southern Comal Counties, Texas}

By Cassi L. Otero

In cooperation with the San Antonio Water System

Scientific Investigations Report 2007-5285 


\section{U.S. Department of the Interior DIRK KEMPTHORNE, Secretary}

\section{U.S. Geological Survey \\ Mark D. Myers, Director}

\section{U.S. Geological Survey, Reston, Virginia: 2007}

For product and ordering information:

World Wide Web: http://www.usgs.gov/pubprod

Telephone: 1-888-ASK-USGS

For more information on the USGS — the Federal source for science about the Earth, its natural and living resources, natural hazards, and the environment:

World Wide Web: http://www.usgs.gov

Telephone: 1-888-ASK-USGS

Any use of trade, product, or firm names is for descriptive purposes only and does not imply endorsement by the U.S. Government.

Although this report is in the public domain, permission must be secured from the individual copyright owners to reproduce any copyrighted materials contained within this report.

Suggested citation:

Otero, C.L., 2007, Geologic, hydrologic, and geochemical identification of flow paths in the Edwards aquifer, northeastern Bexar and southern Comal Counties, Texas: U.S. Geological Survey Scientific Investigations Report 2007$5285,48 \mathrm{p}$. 


\section{Contents}

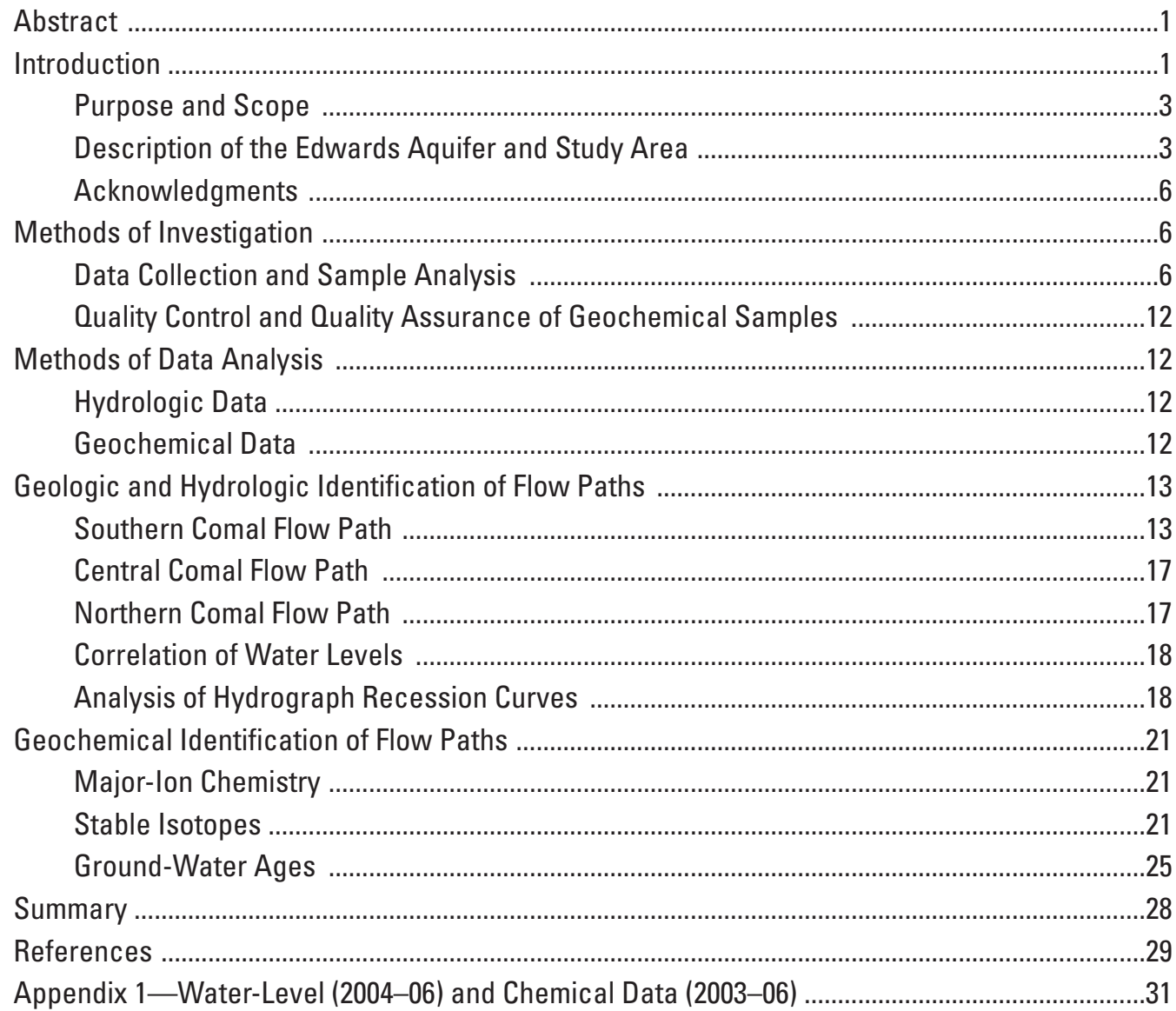

1.1. Daily mean depth to water at well DX-68-22-913, Comal County, Texas,

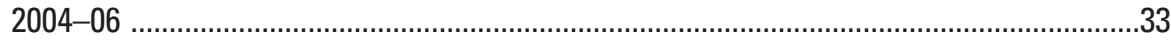

1.2. Daily mean depth to water at well DX-68-23-502, Comal County, Texas, 2004-06 .....36

1.3. Chemical and isotope data in ground-water samples from wells and springs (by flow path) collected for this study, northeastern Bexar and southern Comal Counties, Texas, 2003-06

\section{Figures}

1-3. Maps showing:

1. San Antonio segment of the Edwards aquifer, location of study area, and relation between Edwards and Trinity aquifers, south-central Texas .....

2. Study area and relation between recharge zone and confined zone of the Edwards aquifer and the Trinity aquifer, northeastern Bexar and southern Comal Counties, Texas

3. Locations of major springs in the Comal Springs complex, southern Comal County, Texas 
4. Idealized block diagram of the Edwards aquifer between Comal Springs fault and Hueco Springs fault, southern Comal County, Texas

5-7. Maps showing:

5. Locations of wells and spring orifices from which water-quality samples were collected and locations of continuous water-level observation wells, northeastern Bexar and southern Comal Counties, Texas

6. Locations of hypothesized ground-water flow paths, northeastern Bexar and southern Comal Counties, Texas

7. Potentiometric surface of Edwards aquifer in northeastern Bexar and southern Comal Counties, Texas, fall 2000

8. Hydrographs of water levels from six wells and discharge for Comal Springs and Hueco Springs, northeastern Bexar and southern Comal Counties, Texas, March 2004-September 2006

9. Graph showing correlations between water levels for six wells and discharge for Comal Springs and Hueco Springs, northeastern Bexar and southern Comal Counties, Texas, March 2004-September 2006

10. Hydrographs of discharge at Comal Springs and Hueco Springs, southern Comal County, Texas, March 2004-September 2006, showing recession coefficients for recession curves

11. Trilinear diagrams showing composition of ground water in the Edwards aquifer in the southern, central, and northern Comal flow paths, northeastern Bexar and southern Comal Counties, Texas

12-14. Graphs showing:

12. Relation of calcium concentration to magnesium/calcium ratio in samples collected from wells and springs in the Edwards aquifer and wells in the Trinity aquifer, northeastern Bexar and southern Comal Counties, Texas.

13. Relation between delta oxygen-18 and delta deuterium for selected wells and springs, northeastern Bexar and southern Comal Counties, Texas, 1996-2006, with insert showing same plot with axes extended to range of rainfall samples

14. Apparent ages of ground water in 2003 samples from selected wells and springs in the Edwards aquifer, northeastern Bexar and southern Comal Counties, Texas, based on sulfur hexafluoride concentration

15. Maps showing apparent age of water in selected wells in the Edwards aquifer, northeastern Bexar and southern Comal Counties, Texas, based on tritium/helium-3 ratio

\section{Table}

1. Ground-water sites (wells, springs, and spring orifices), springflow sites, and rainfall sites, northeastern Bexar and southern Comal Counties, Texas, from which data were collected and compiled for this report 


\section{Datums and Abbreviations}

Vertical coordinate information is referenced to the National Geodetic Vertical Datum of 1929 (NGVD 29) or the North American Vertical Datum of 1988 (NAVD 88).

Horizontal coordinate information is referenced to the North American Datum of 1983 (NAD 83).

Altitude, as used in this report, refers to distance above the vertical datum.

Specific conductance is given in microsiemens per centimeter at 25 degrees Celsius $(\mu \mathrm{S} / \mathrm{cm})$.

Concentrations of chemical constituents in water are given in either milligrams per liter (mg/L) or micrograms per liter $(\mu \mathrm{g} / \mathrm{L})$. 



\title{
Geologic, Hydrologic, and Geochemical Identification of Flow Paths in the Edwards Aquifer, Northeastern Bexar and Southern Comal Counties, Texas
}

\author{
By Cassi L. Otero
}

\section{Abstract}

The U.S. Geological Survey, in cooperation with the San Antonio Water System, conducted a 4-year study during 2002-06 to identify major flow paths in the Edwards aquifer in northeastern Bexar and southern Comal Counties (study area). In the study area, faulting directs ground water into three hypothesized flow paths that move water, generally, from the southwest to the northeast. These flow paths are identified as the southern Comal flow path, the central Comal flow path, and the northern Comal flow path. Statistical correlations between water levels for six observation wells and between the water levels and discharges from Comal Springs and Hueco Springs yielded evidence for the hypothesized flow paths. Strong linear correlations were evident between the datasets from wells and springs within the same flow path and the datasets from wells in areas where flow between flow paths was suspected. Geochemical data (major ions, stable isotopes, sulfur hexafluoride, and tritium and helium) were used in graphical analyses to obtain evidence of the flow path from which wells or springs derive water. Major-ion geochemistry in samples from selected wells and springs showed relatively little variation. Samples from the southern Comal flow path were characterized by relatively high sulfate and chloride concentrations, possibly indicating that the water in the flow path was mixing with small amounts of saline water from the freshwater/saline-water transition zone. Samples from the central Comal flow path yielded the most varied major-ion geochemistry of the three hypothesized flow paths. Central Comal flow path samples were characterized, in general, by high calcium concentrations and low magnesium concentrations. Samples from the northern Comal flow path were characterized by relatively low sulfate and chloride concentrations and high magnesium concentrations. The high magnesium concentrations characteristic of northern Comal flow path samples from the recharge zone in Comal County might indicate that water from the Trinity aquifer is entering the Edwards aquifer in the subsurface. A graph of the relation between the stable isotopes deuterium and delta- 18 oxygen showed that, except for samples collected following an unusually intense rain storm, there was not much variation in stable isotope values among the flow paths. In the study area deuterium ranged from -36.00 to -20.89 per mil and delta-18 oxygen ranged from -6.03 to -3.70 per mil. Excluding samples collected following the intense rain storm, the deuterium range in the study area was -33.00 to -20.89 per mil and the delta- 18 oxygen range was -4.60 to -3.70 per mil. Two ground-water age-dating techniques, sulfur hexafluoride concentrations and tritium/helium-3 isotope ratios, were used to compute apparent ages (time since recharge occurred) of water samples collected in the study area. In general, the apparent ages computed by the two methods do not seem to indicate direction of flow. Apparent ages computed for water samples in northeastern Bexar and southern Comal Counties do not vary greatly except for some very young water in the recharge zone in central Comal County.

\section{Introduction}

The Edwards aquifer is the main source of public water supply for the city of San Antonio, Texas, and the surrounding area and provides nearly all of the water for industrial, military, and irrigation use in the region (fig.1). Withdrawals from the aquifer to meet San Antonio's increasing water-supply needs might be a threat to minimum mandated sustained flows at Comal Springs (Edwards Aquifer Authority, 2007), the largest spring in the Southwest. The springs supply water to downstream users, sustain federally-listed endangered species, and support local economies through tourism. Increased knowledge of the complex hydrologic processes that control water availability in the Edwards aquifer in the vicinity of Comal Springs is imperative for optimal resource management. The U.S. Geological Survey (USGS), in cooperation with the San Antonio Water System (SAWS), conducted a 4-year study during 2002-06 in northeastern Bexar County and southern Comal County to identify flow paths in the Edwards aquifer. The study area (fig. 1) includes small parts 


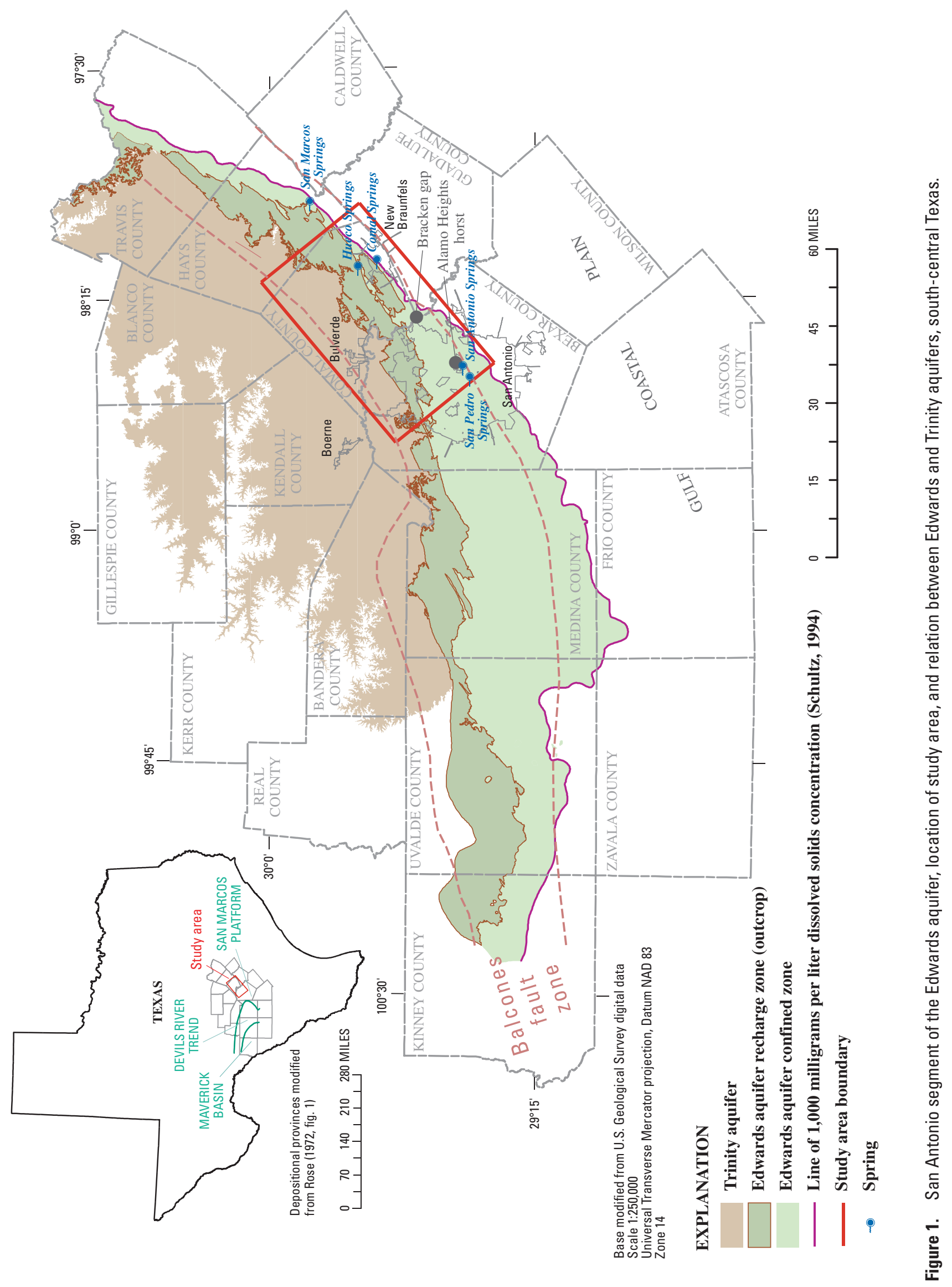


of Guadalupe and Hays Counties in addition to northeastern Bexar County and southern Comal County.

\section{Purpose and Scope}

The purpose of this report is to describe major groundwater flow paths in the Edwards aquifer in northeastern Bexar and southern Comal Counties identified on the basis of geologic, hydrologic, and geochemical data. Hydrogeology and geologic structure based on work done by Maclay and Small (1984), Small (1986), Small and Hanson (1994), Maclay (1995), and Stein and Ozuna (1994) and flow path work done by Maclay and Land (1988) and Groschen (1996) provided a basis for the initial selection of hypothesized flow paths in the study area. Flow paths were further defined using hydrologic data collected from water-level observation wells and springflow monitoring sites in the study area. Altitudes of the potentiometric surface within each flow path provided evidence of flow directions. Comparisons of water-level and spring-discharge hydrographs and statistical correlation of water levels and spring discharges were used to show relations between water levels at wells and spring discharges within flow paths. Continuous water-level data were collected at six observation wells from mid-March 2004 through September 2006. Discharge data were obtained from two springflow sites for the same time period. Ground-water chemistry and isotope data were compiled from samples collected from 76 wells and nine springs (and spring orifices of major springs) during 1996-2006. Isotope data also were obtained from samples collected at four rainfall sites during 1998-2003.

\section{Description of the Edwards Aquifer and Study Area}

The San Antonio segment of the Edwards aquifer (hereinafter, Edwards aquifer) comprises Lower Cretaceous-age rocks of the Edwards Group (Rose, 1972) and the Georgetown Formation. The Edwards Group in the study area comprises two stratigraphic units, the basal Kainer Formation and the upper Person Formation. Each of those units comprises several informal members. The basal member of the Person Formation is a laterally extensive marine deposit consisting of poorly permeable, dense, carbonate mudstone known as the regional dense member (Maclay, 1995).

Most recharge to the Edwards aquifer occurs in the recharge zone (aquifer outcrop) west of Bexar County (fig. 1), where streams originating north of the aquifer flow across and lose most or all of their flows into highly faulted and fractured limestone. Additional recharge enters the aquifer through the recharge zone in Bexar, Comal, and Hays Counties. After the water enters the aquifer, it moves generally in an easterly direction to discharge points in Bexar County, mainly municipal water-supply wells. Water not discharged to wells then continues generally toward the northeast along and parallel to northeast-trending faults in the study area to discharge points in Comal and Hays Counties, primarily Comal Springs in Comal County and San Marcos Springs in Hays County (fig. 1).

The study area is in an extensively faulted section of Cretaceous strata known as the Balcones fault zone (fig. 1). The fault zone developed as a result of extensional faulting and is characterized by a network of en-echelon, high-angle, mostly down-to-the-coast normal faults along the northwestern margin of the Gulf Coastal Plain (Maclay and Small, 1984; Maclay, 1995). The Cretaceous strata were vertically displaced, intensively fractured, and differentially rotated within a series of southwest-to-northeast trending fault blocks (Barker and Ardis, 1996). The fault blocks, and their subsequent erosion and dissolution, are major factors affecting flow in the aquifer.

Maclay and Land (1988, fig. 22) defined four major flow units in the Edwards aquifer. The flow units originate in areas referred to as storage units in the recharge zone and are regions of confined flow that generally move water initially to the southwest and then to the east and northeast to discharge at major springs. The eastern flow unit described by Maclay and Land (1988) originates in the study area. The western-southern, south-central, and north-central flow units coalesce in northeastern Bexar County and southern Comal County in the vicinity of Cibolo Creek and Interstate Highway 35.

Maclay and Small (1984, p. 50) estimated transmissivities for the Edwards aquifer to range from 200,000 to 2,000,000 feet squared per day. Maclay and Small (1984) describe one of the most transmissive areas in the Edwards aquifer as occurring within a narrow, northeast-trending band downgradient from the area of coalescence of the three southernmost flow units. This band of high transmissivity (fig. 2) (labeled "R" in Maclay and Small [1984, fig. 20]) is bounded on the northwest and southeast by faults where less-permeable rocks of the upper confining unit of the aquifer are juxtaposed against rocks of the Edwards aquifer.

Recharge to and flow within the Edwards aquifer in northeastern Bexar and southern Comal Counties are complicated by the structure and stratigraphy of the rocks. The study area (fig. 1) is on the structural high known as the San Marcos Platform (Rose, 1972). The San Marcos Platform is extensively faulted in the study area. The thickness of the Edwards aquifer in the study area is about 450 feet (Small and Hanson, 1994, p. 5; Stein and Ozuna, 1994, p. 5). Three major faults, the Comal Springs fault and the Hueco Springs fault in southern Comal County and the Northern Bexar fault (Maclay and Land, 1988) in northeastern Bexar County, are potentially effective barriers to flow in the Edwards aquifer in the study area (fig. 2).

The Comal Springs complex (fig. 3) issues from the Comal Springs fault, which has as much as 500 feet of offset (Maclay and Land, 1988, p. A42) and is juxtaposed against the younger and less permeable upper confining unit. The springs developed because a roughly north-south trending transverse fault east of New Braunfels completely offsets the Edwards aquifer in the downthrown block of the Comal Springs fault, 


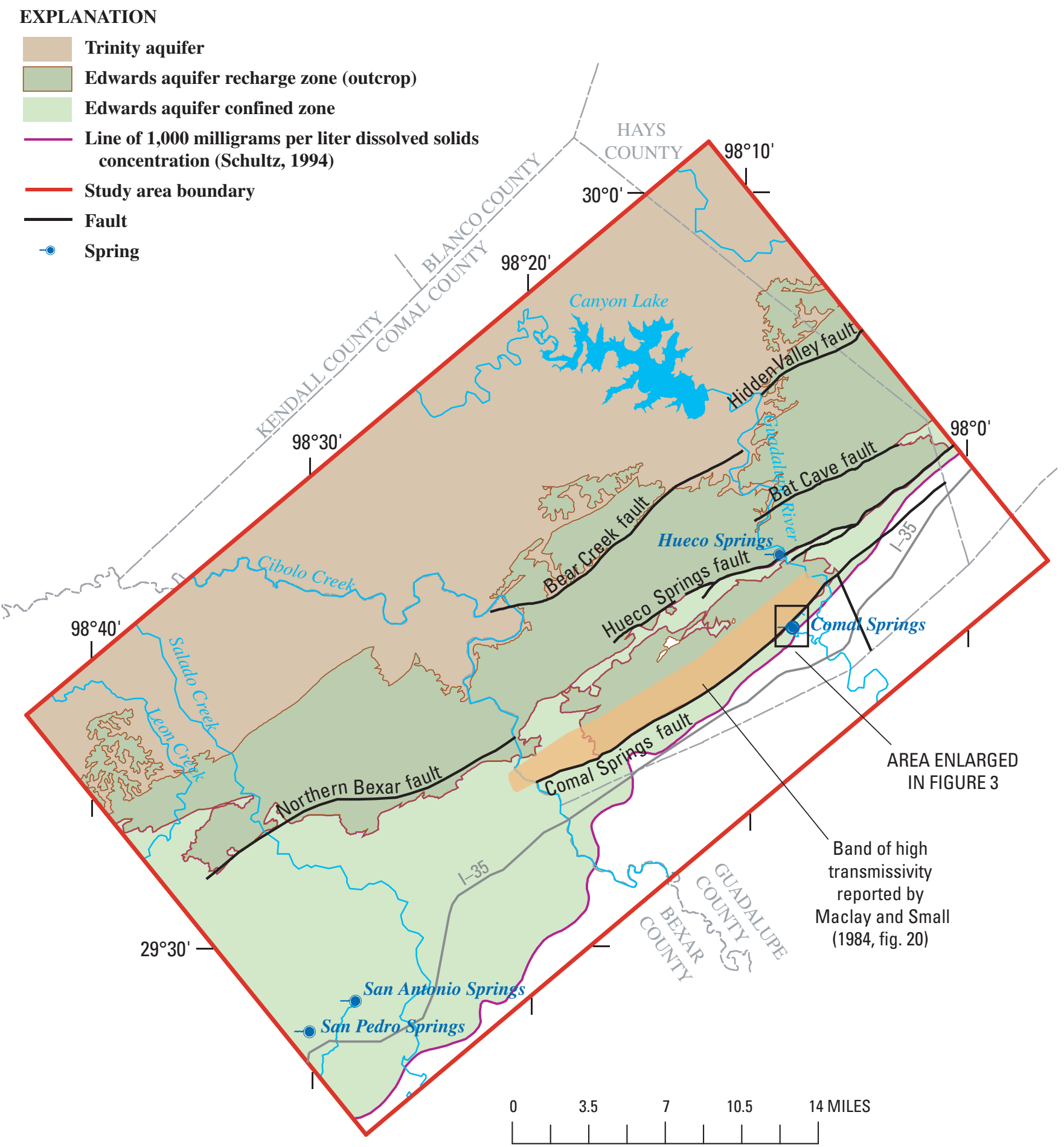

Figure 2. Study area and relation between recharge zone and confined zone of the Edwards aquifer and the Trinity aquifer, northeastern Bexar and southern Comal Counties, Texas.

creating a barrier to northeastward flow and forcing water upward along the Comal Springs fault (Klemt and others, 1979, fig. 8). About one-fourth of the springflow from the Comal Springs complex discharges from three large spring orifices (Comal 1, Comal 2, and Comal 3 on the west side of the complex) that are sourced in the upthrown block of the
Comal Springs fault (Ogden and others, 1985; LBG-Guyton Associates, 2004). The remaining springflow is discharged from numerous spring orifices and seeps that are within and near the banks of Landa Lake; these springs and seeps are sourced in the downthrown block of the Comal Springs fault. 


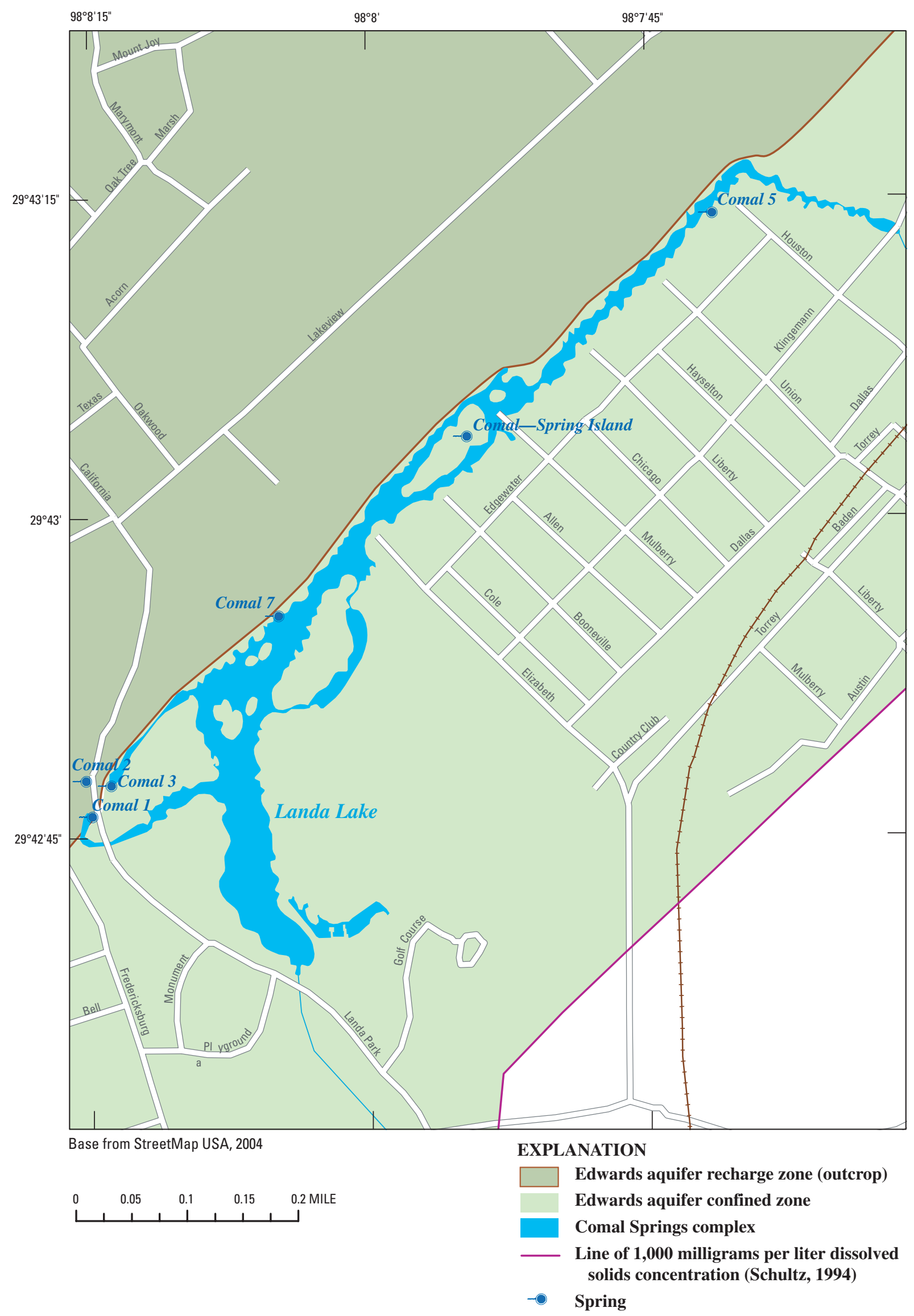

Figure 3. Locations of major springs in the Comal Springs complex, southern Comal County, Texas. 
Hueco Springs issues from the Hueco Springs fault (fig. 2), which has 380 to 400 feet of offset in the vicinity of the springs (William F. Guyton and Associates, 1979, p. 25) and exposes much of the less-permeable upper confining unit on the downthrown block. The series of fault blocks immediately adjacent to and southeast of the Hueco Springs fault in southern Comal County are oriented mainly down-tothe-northwest (fig. 4). Consequently, this section of Edwards aquifer between the Hueco Springs fault and the Comal Springs fault is in a graben that is tilted opposite to the prevailing structure in the area. The fault blocks near Hueco Springs fault generally contain the entire thickness of the Edwards aquifer and parts of the upper confining unit, whereas the fault blocks near Comal Springs fault generally contain incomplete, unconfined sections of the Edwards aquifer exposed at the surface. The fault blocks contain numerous transverse faults that possibly impede ground-water flow. Northwest of Hueco Springs fault are faults that probably are not effective barriers to flow, including Bat Cave, Bear Creek, and Hidden Valley faults (fig. 2).

\section{Acknowledgments}

Thanks are extended to SAWS and other well owners who granted permission to have their wells sampled for water quality and measured for water levels. Special thanks are extended to Hanson Aggregates, Inc., and New Braunfels Utility (NBU) for access to their wells for use as real-time, continuous water-level observation sites for this study.

\section{Methods of Investigation}

\section{Data Collection and Sample Analysis}

Six wells were used for the collection of continuous water-level data (fig. 5; table 1). Two real-time, continuous water-level data-collection sites-DX-68-22-913 (Hanson) and DX-68-23-502 (Solms) - were established to collect hourly ground-water-level data for this study (appendix 1.1, 1.2). Water-level data also were compiled on an hourly basis from four existing USGS real-time, continuous ground-waterlevel observation wells-AY-68-29-103 (HCV), AY-68-37203 (Bexar), DX-68-23-304 (NBU-LCRA), and DX-68-30208 (Bracken). Collection of continuous water-level data at the observation wells began in mid-March 2004 and continued through September 2005 at wells HCV and Bracken and through September 2006 at the four other wells. USGS-computed springflow data for Comal Springs and Hueco Springs also were compiled for mid-March 2004 through September 2006. All water-level and spring-flow data are in the USGS National Water Information System for Texas (U.S. Geological Survey, 2006a).
Ground-water-chemistry and isotope data were collected and compiled from 76 wells and nine springs (and spring orifices from major springs) during 1996-2006 (fig. 5; table 1). Data were collected for this study during 2003 (and during 2006 at selected sites). Additional data were collected during 1996-2006 as part of the National Water Quality Assessment (NAWQA) program (U.S. Geological Survey, 2006c). Two wells and two springs provided data from both sampling periods. Sixty-three wells and two springs provided NAWQA data only. Eleven wells and five springs provided data only for this study.

Samples were collected for dissolved gases (methane, carbon dioxide, oxygen, nitrogen, and argon), sulfur hexafluoride $\left(\mathrm{SF}_{6}\right)$, and tritium $\left({ }^{3} \mathrm{H}\right)$ and helium-3 $\left({ }^{3} \mathrm{He}\right)$ concentrations from 13 wells and seven springs during 2003 (table 1; appendix 1.3$) .{ }^{3} \mathrm{H} /{ }^{3} \mathrm{He}$ ratios were computed and used to estimate an apparent age (year sampled minus recharge year) of the water. Four wells (DX-68-22-810, DX-68-22-905, DX-68-23304, and DX-68-23-710) and six springs (Comal 1, Comal 3, Comal 5, Comal 7, Comal-Spring Island, and Hueco A) were resampled in 2006 for ${ }^{3} \mathrm{H} /{ }^{3} \mathrm{He}$ because samples collected in 2003 resulted in either inconclusive or questionable age dates for these wells and springs. The 2006 sample for well DX-6822-810 resulted in an inconclusive age date.

Isotope data were collected and compiled from four rainfall sites (fig. 5, table 1). Two sites provided only data collected in 1998 as part of the NAWQA program (U.S. Geological Survey, 2006c). The remaining two sites provided both NAWQA data and 2003 data.

Water-chemistry data included field properties (water temperature, $\mathrm{pH}$, specific conductance, and dissolved oxygen), major ions, trace elements, nutrients, and alkalinity. Water samples were collected, processed, and preserved using standard USGS protocols as described in Wilde and others (1999, 2003, and 2004). The concentrations of major ions, trace elements, and nutrients in the water samples were measured by the USGS National Water Quality Laboratory in Denver, Colo., using approved methods (Fishman and Friedman, 1989; Patton and Truitt, 1992, 2000; Faires, 1993; Fishman, 1993; American Public Health Association, 1998; Garbarino and others, 2006).

The ratios of naturally occurring, stable isotopes of hydrogen $\left({ }^{2 / 1} \mathrm{H}\right)$ and oxygen $\left({ }^{18 / 16} \mathrm{O}\right)$ were measured by the USGS Stable Isotope Laboratory in Reston, Va., using approved methods (U.S. Geological Survey, 2005). Results for stable isotope analysis are reported as delta deuterium $(\delta \mathrm{D})$ and delta 18-oxygen $\left(\delta^{18} \mathrm{O}\right)$, which represent the relative difference in parts per thousand (per mil) between the sample isotope ratio and the isotope ratio of a known standard (Kendall and McDonnell, 1998).

Dissolved gases and $\mathrm{SF}_{6}$ samples were analyzed by the USGS Chlorofluorocarbon Laboratory in Reston, Va., using approved methods (U.S. Geological Survey, 2006b). ${ }^{3} \mathrm{H} /{ }^{3} \mathrm{He}$ samples collected in 2003 were analyzed by personnel at the Nobel Gas Laboratory of Lamont-Doherty Earth Observatory in Palisades, N.Y., and samples collected in 2006 were 

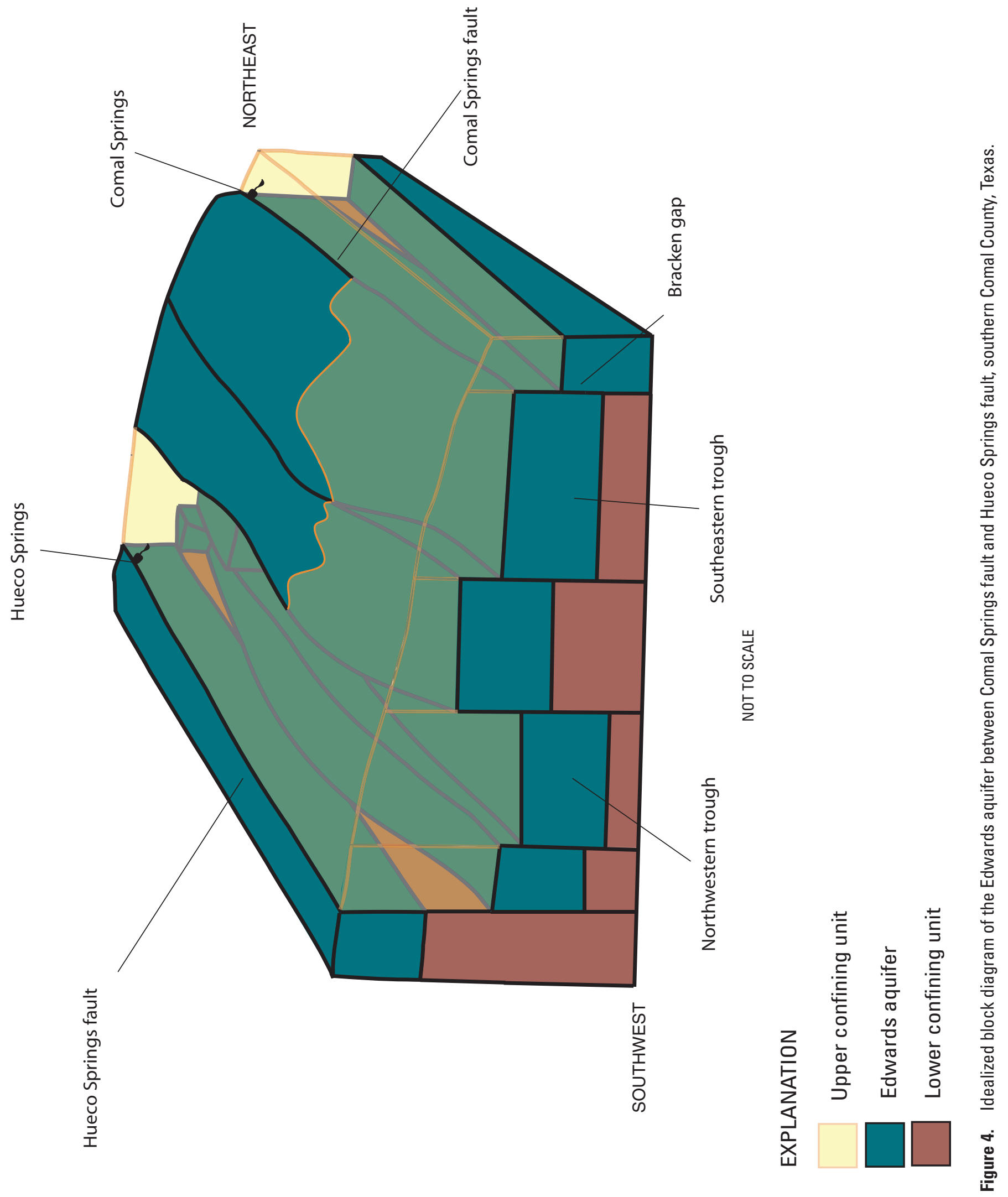


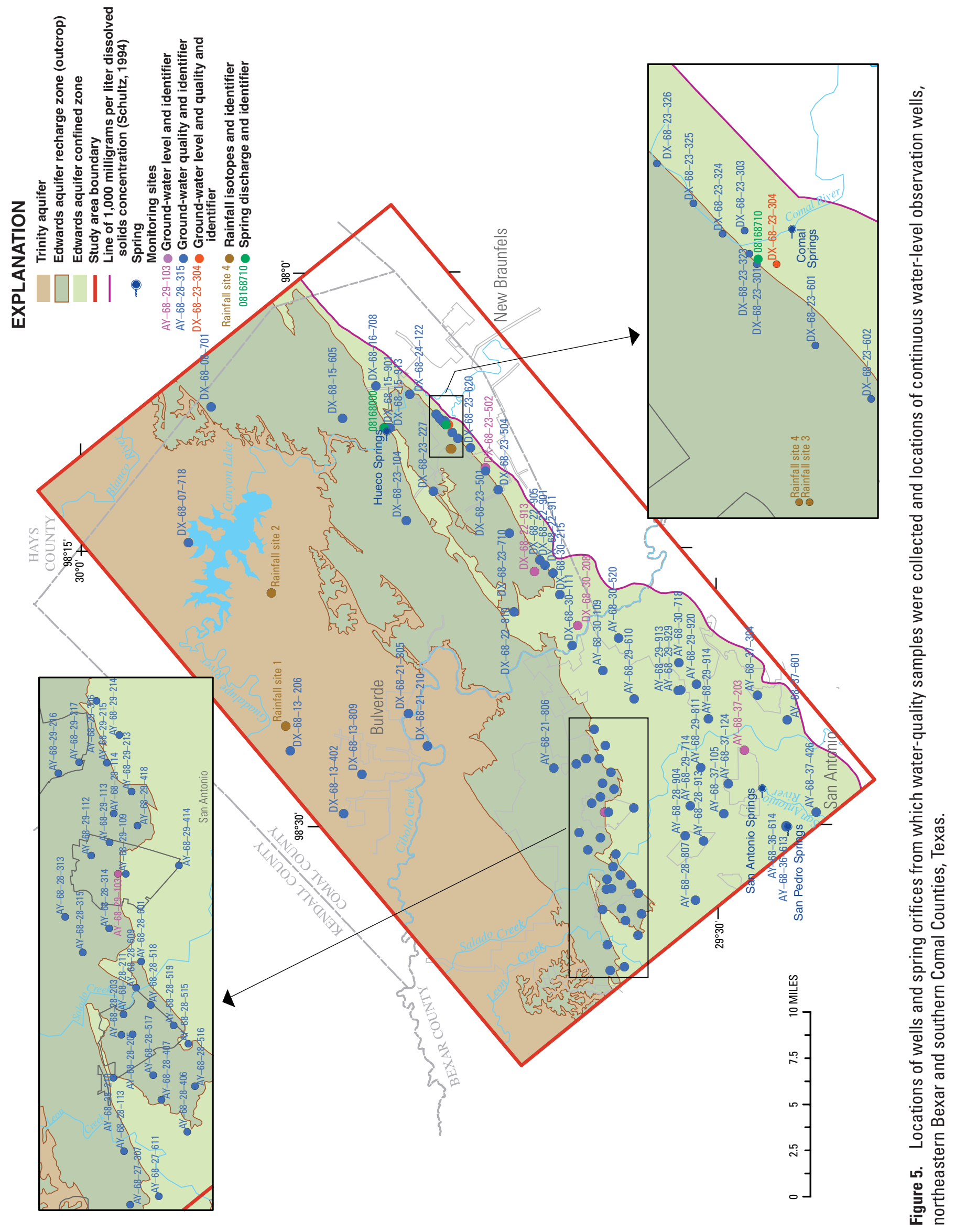




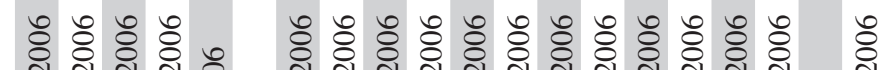

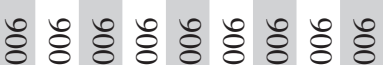

ن

3

क्ष

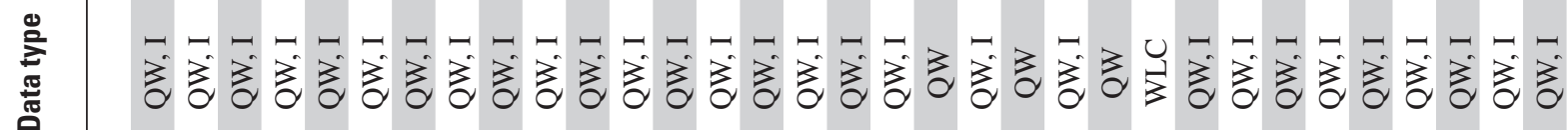

苚

ฟิ

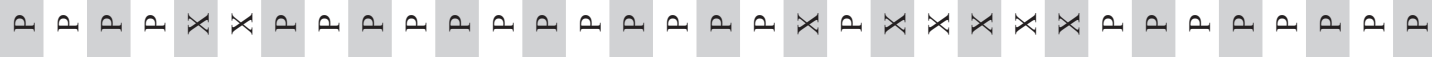

2i 3

궁

\&

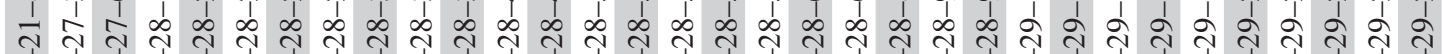

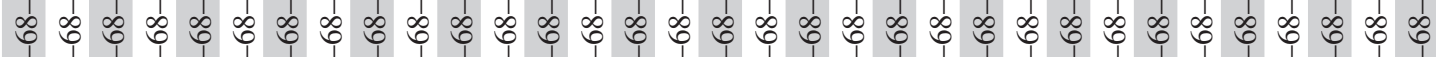

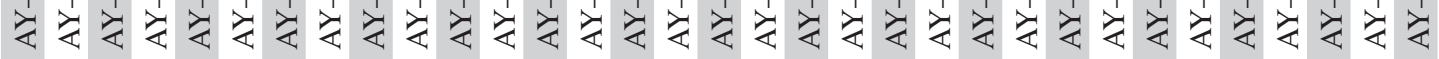




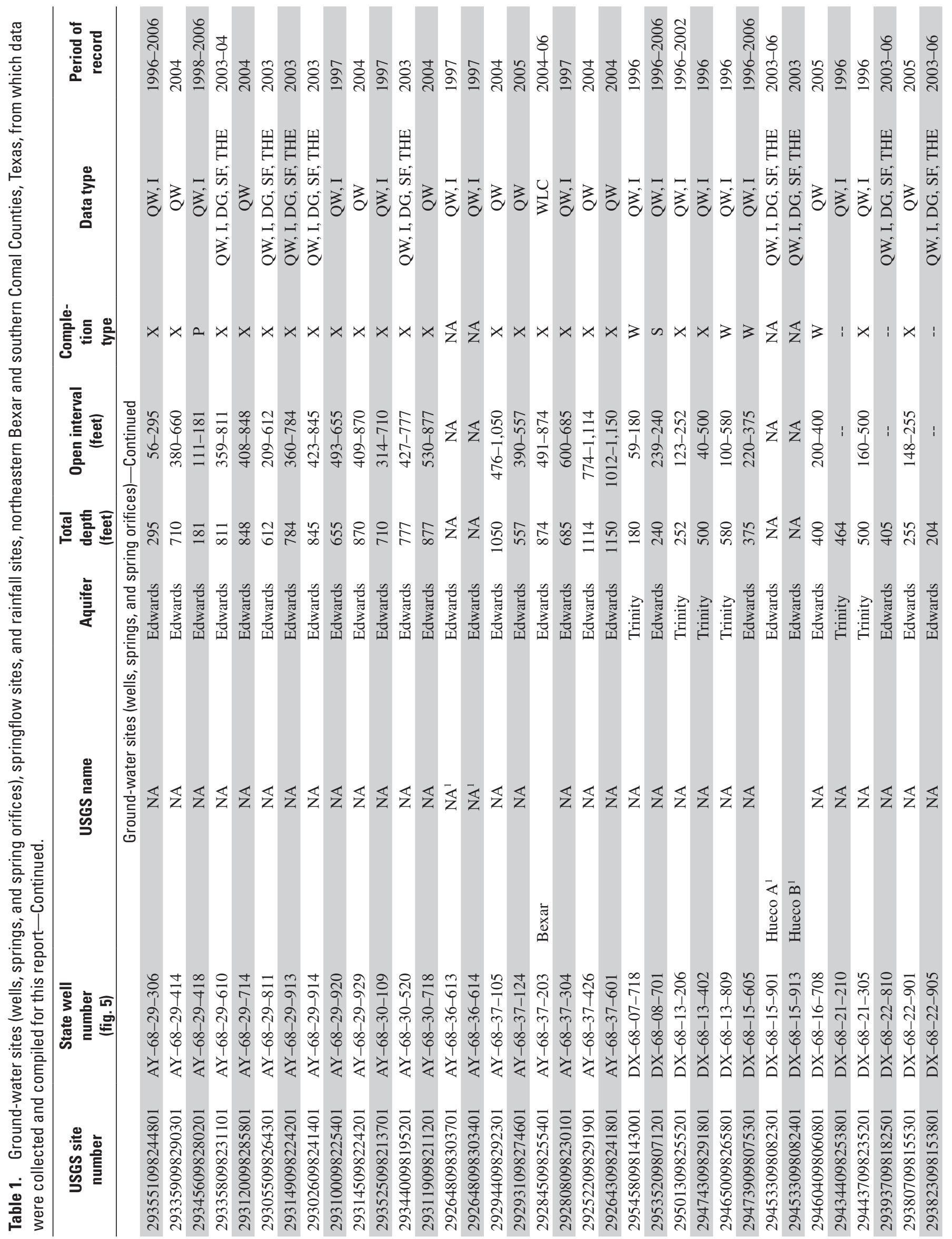




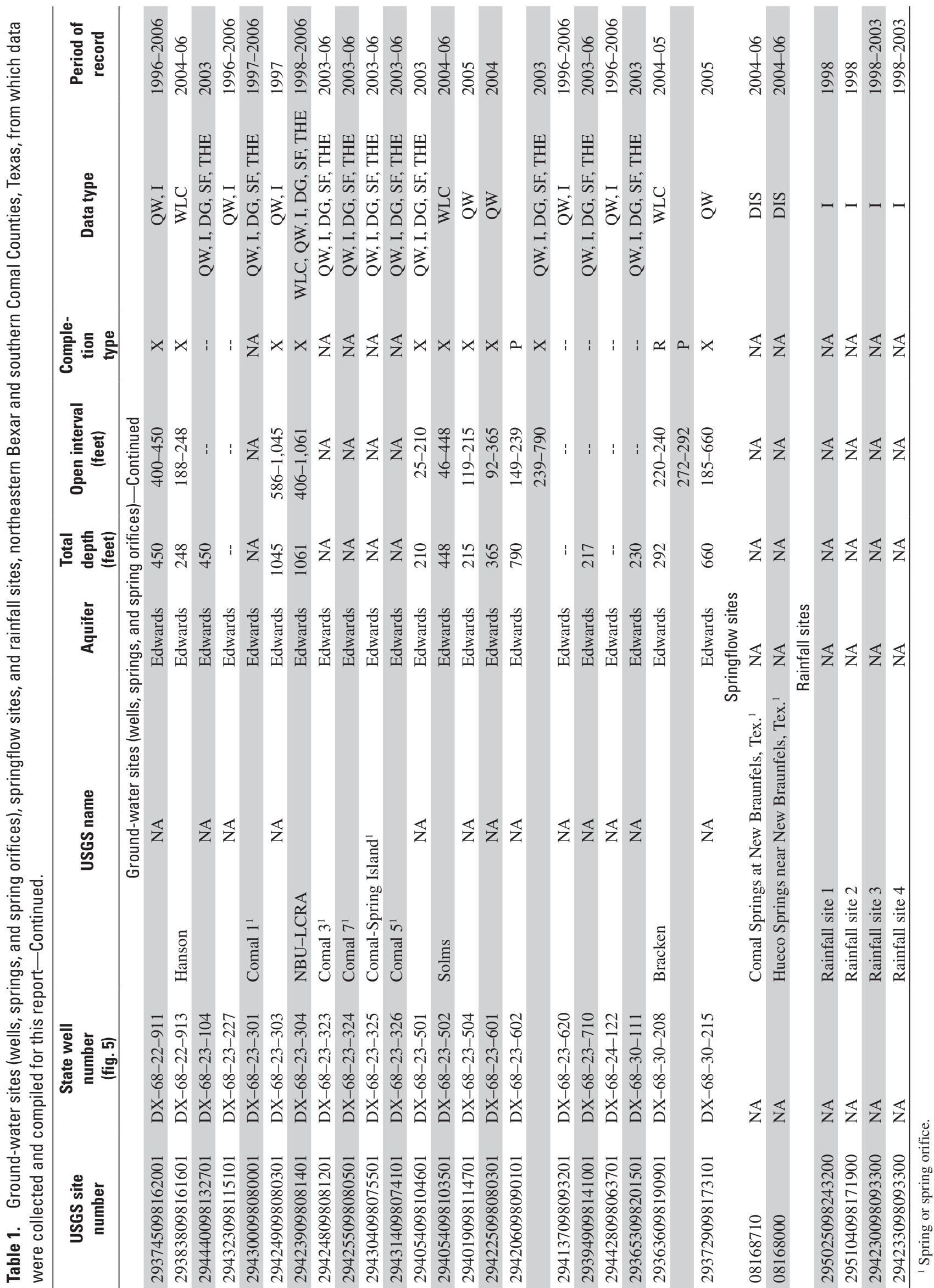


analyzed by USGS personnel at the USGS Noble Gas Laboratory in Denver, Colo., using approved methods (U.S. Geological Survey, 2006b).

\section{Quality Control and Quality Assurance of Geochemical Samples}

Duplicate samples for major ions and trace elements were collected from one of the 13 wells (DX-68-23-710) sampled for this study (appendix 1.3). Duplicate samples for $\mathrm{SF}_{6}$ were collected from all 13 wells sampled for this study. Duplicate samples for major ions, trace elements, and nutrients collected during 1996-2006 as part of the NAWQA program (U.S. Geological Survey, 2006c) were available for seven of the 65 wells supplying existing data for this study. Duplicate samples for major ions, trace elements, and nutrients were collected at one of the seven springs (DX-68-23-325) sampled for this study (appendix 1.3). Duplicate samples for $\mathrm{SF}_{6}$ were collected from all seven springs sampled for this study.

Duplicate samples were used to evaluate the methods used by field and laboratory personnel to collect and analyze a given sample with consistent results. The nonzero relative percent differences between environmental and duplicate samples collected for major ions, trace elements, and nutrients for this study ranged from 0.41 percent for nickel in the spring sample to 54.5 percent for molybdenum in the spring sample with a median value of 3.1 percent. The greatest relative percent difference between the environmental and duplicate samples collected for $\mathrm{SF}_{6}$ for this study was 10.3 percent in well DX-68-23-304.

\section{Methods of Data Analysis}

\section{Hydrologic Data}

Water levels measured in wells in the Edwards aquifer during October 30-November 3, 2000, in a multi-agency effort headed by the Edwards Aquifer Authority (Hamilton and Schindel, 2006) were used to construct a potentiometric-surface map for the study area. Water-level contours within each flow path were examined to determine flow directions in the Edwards aquifer.

Hydrographs of water levels at the six observation wells and discharge at Comal Springs and Hueco Springs were compared. Similarities in the water-level hydrographs might indicate either that the wells are responding to a wide-spread recharge event or that they are in the same flow path. Similarities in hydrographs for the spring discharge and water levels in wells could indicate that the spring and wells share the same flow path.

Statistical correlations between datasets of water levels for the six observation wells and discharge for Comal
Springs and Hueco Springs were analyzed using Pearson's r (Helsel and Hirsch, 1995). Pearson's r (or linear correlation coefficient) is a measure of the linear association between two variables. Pearson's $r$ was calculated for each of the 28 combinations of datasets to indicate the strength of the linear association (correlations) between datasets. The assumption was that a strong linear correlation indicates a higher probability of a shared or common flow path than a nonlinear correlation or no correlation.

Hydrograph recession-curve analysis was done on spring-discharge hydrographs to identify the number and type of flow regimes (diffuse, fracture, and conduit) that characterize the ground-water flow path contributing to the spring. Hydrographs of spring discharge at Comal Springs and Hueco Springs were graphed, and recession curves (sections of the hydrograph where the discharge is falling after a sudden rise) spanning the study period were examined. Methods in Milanovich (1981), Bonacci (1993), Padilla and others (1994), Shevenell (1996), and Baedke and Krothe (2001) were used to examine the recession curves for breaks in the recession slope, which are indicative of a change from one flow regime to another within the karst continuum. A recession coefficient $(\alpha)$ was calculated for each part of the karst continuum. The value of $\alpha$ relates to the rate of release of water from the aquifer. In general, higher values of $\alpha$ indicate a steeper slope in the recession curve, and therefore, a release of water from conduit-type features in the aquifer, whereas lower values of $\alpha$ indicate a gentler recession slope and release of water from diffuse (matrix) features of the aquifer.

\section{Geochemical Data}

Geochemical data collected and compiled from selected wells and springs in the Edwards and Trinity aquifers in the study area were used to assess major-ion chemistry and apparent ground-water age (table 1). Ground-water flow paths were analyzed using geochemical and isotopic data. Additional ${ }^{18 / 16} \mathrm{O}$ and ${ }^{2 / 1} \mathrm{H}$ isotopic concentrations were estimated from rainfall samples to determine the local meteoric water line.

Dissolved gases and $\mathrm{SF}_{6}$ were used to determine apparent age (year sampled minus recharge year) of ground-water samples. Apparent age is determined by comparing the concentration of $\mathrm{SF}_{6}$ in the water sample to an established annual atmospheric concentration (Busenberg and Plummer, 2000). $\mathrm{SF}_{6}$ is a trace gas in the atmosphere that accumulates in rainfall that eventually becomes recharge to the ground-water system. Mainly an anthropogenic compound, $\mathrm{SF}_{6}$ also can occur naturally in fluid inclusions in some minerals and igneous rocks and in some volcanic and igneous fluids. Apparent age derived using this method does not take into account the mixing of young and old waters. The addition of excess air into the ground-water system, which can occur when air bubbles are dissolved during a rapid rise of the water table, increases the $\mathrm{SF}_{6}$ concentration in the ground water to levels greater than the air-water equilibrium concentration. If the existence of 
excess air is not considered in the computation of the recharge year, then the apparent age will be too young.

Apparent ages also were obtained using a method that involves measuring the relative abundance of tritium $\left({ }^{3} \mathrm{H}\right)$ and helium-3 $\left({ }^{3} \mathrm{He}\right)$ in a water sample. Tritium is a radioactive isotope of hydrogen that decays to ${ }^{3} \mathrm{He}$ with a half-life of 12.43 years. Tritium was introduced into the ground-water system in a series of peaks beginning in 1952, caused by atmospheric testing of nuclear devices, and reached a maximum concentration during 1963-64 (Schlosser and others, 1988). Although tritium concentrations in rainfall generally have decreased since this mid-1960s peak, an annual atmospheric concentration remains. Using a helium isotope mass balance, the amount of ${ }^{3} \mathrm{He}$ from the decay of ${ }^{3} \mathrm{H}$ (tritiogenic ${ }^{3} \mathrm{He}$ denoted as ${ }^{3} \mathrm{He} *$ ) is measured with the remaining ${ }^{3} \mathrm{H}$ in the water sample (Plummer and others, 2003). The values are added to determine the amount of ${ }^{3} \mathrm{H}$ that was present in the water sample at the time of recharge to the ground-water system. This calculated recharge concentration of ${ }^{3} \mathrm{H}$ then is compared to the established annual atmospheric concentration to determine an apparent age or recharge year for the water sample. This method of age-dating a water sample has proved to be effective for waters recharged within about the past 30 years and takes into account the mixing of young and old waters. Problems arise with this method when large amounts of terrigenic helium (derived from crustal or mantle sources) are present in a sample, such as in aquifers with host rock containing uranium or thallium, or in samples where young water has mixed with relatively old water containing terrigenic helium sources. In these cases, the ratio of ${ }^{3} \mathrm{He} /{ }^{4} \mathrm{He}$ for the terrigenic helium must be known within about 1 percent to determine an apparent age. If this ratio cannot be defined within the 1-percent limit, a range in age can be evaluated for a range in the terrigenic helium ratio (Schlosser and others, 1988).

Major-ion and stable isotope data were graphically evaluated to determine relations among constituents that could distinguish differences between flow paths in the study area. Piper trilinear diagrams were used to visually categorize the principal water compositions for each flow path (Hem, 1992). Scatterplots of constituents and ratios of constituents were constructed to graphically indicate variations in water samples collected from wells from different flow paths.

\section{Geologic and Hydrologic Identification of Flow Paths}

\section{Southern Comal Flow Path}

The southern Comal flow path (SCFP) (fig. 6) is bounded on the northwest by the Comal Springs fault and on the southeast by the freshwater/saline-water interface (threshold of 1,000-milligrams per liter ( $\mathrm{mg} / \mathrm{L}$ ) dissolved solids concentration [Schultz, 1994]) in the Edwards aquifer (fig. 1). Although the interface is not an actual physical barrier to flow, previous studies (Maclay and Small, 1984; Groschen, 1994; Lindgren and others, 2004) have indicated that flow in the transition zone (zone in which dissolved solids concentration ranges from 1,000 to $10,000 \mathrm{mg} / \mathrm{L}$ ) is considerably more sluggish than flow in the immediately adjacent freshwater zone, likely because of relatively low permeability and transmissivity in the transition zone. The 1,000-mg/L threshold was selected as the boundary because that concentration historically has been considered the separation between the freshwater and salinewater zones of the aquifer and is a well-documented marker within the aquifer.

The potentiometric-surface map constructed from data collected in fall 2000 in a multi-agency effort organized by the Edwards Aquifer Authority indicates that water within the SCFP flows from southwest to northeast from areas of higher water-level altitude to areas of lower water-level altitude (fig. 7). Recharge to the SCFP is primarily regional, occurring in the Edwards aquifer recharge zone west of the study area. The Comal Springs fault fails to offset the entire thickness of the Edwards aquifer near the area where the boundaries of Bexar, Comal, and Guadalupe Counties come into contact. Maclay and Land (1988) referred to this area as the Bracken gap (fig. 6). Subsurface inflow to the SCFP can occur as ground water spills over from north of Comal Springs fault across the Bracken gap. The permeable sections of the aquifer in the SCFP, although faulted, are juxtaposed in a manner that promotes the flow of ground water in the study area from the center of Bexar County through southern Comal County. The ground water then encounters a transverse fault northeast of New Braunfels (fig. 6) that forms a barrier to ground-water flow and is forced up along the Comal Springs fault and through the overlying gravels to form a majority of the springs and seeps in the Comal Springs complex. The SCFP gradually narrows as it nears Comal Springs because saline water encroaches as the freshwater is discharged at the springs. The transmissivity in the freshwater zone of the Edwards aquifer southeast of the Comal Springs fault in southern Comal County is greater than in any other part of the aquifer (Maclay and Small, 1984).

Water-level hydrographs for wells Bexar, Bracken, Solms, and NBU-LCRA and the discharge hydrograph for Comal Springs (fig. 8) provided evidence of patterns of ground-water flow in the SCFP. The hydrographs for the four wells and Comal Springs fluctuated in a similar manner, possibly indicating a common flow path for ground water flowing past the wells and discharging at Comal Springs. Wells Bexar and Bracken showed larger magnitudes of fluctuation than did wells Solms and NBU-LCRA. This indicates that amplitude of the pressure wave moving through the confined section of the aquifer likely is decreased by the substantial increase in horizontal hydraulic conductivity of the aquifer in the SCFP near Comal Springs. The relatively flat potentiometric surface near Comal Springs (fig. 7) also provides evidence of higher horizontal hydraulic conductivity at the northeastern end of the SCFP. 


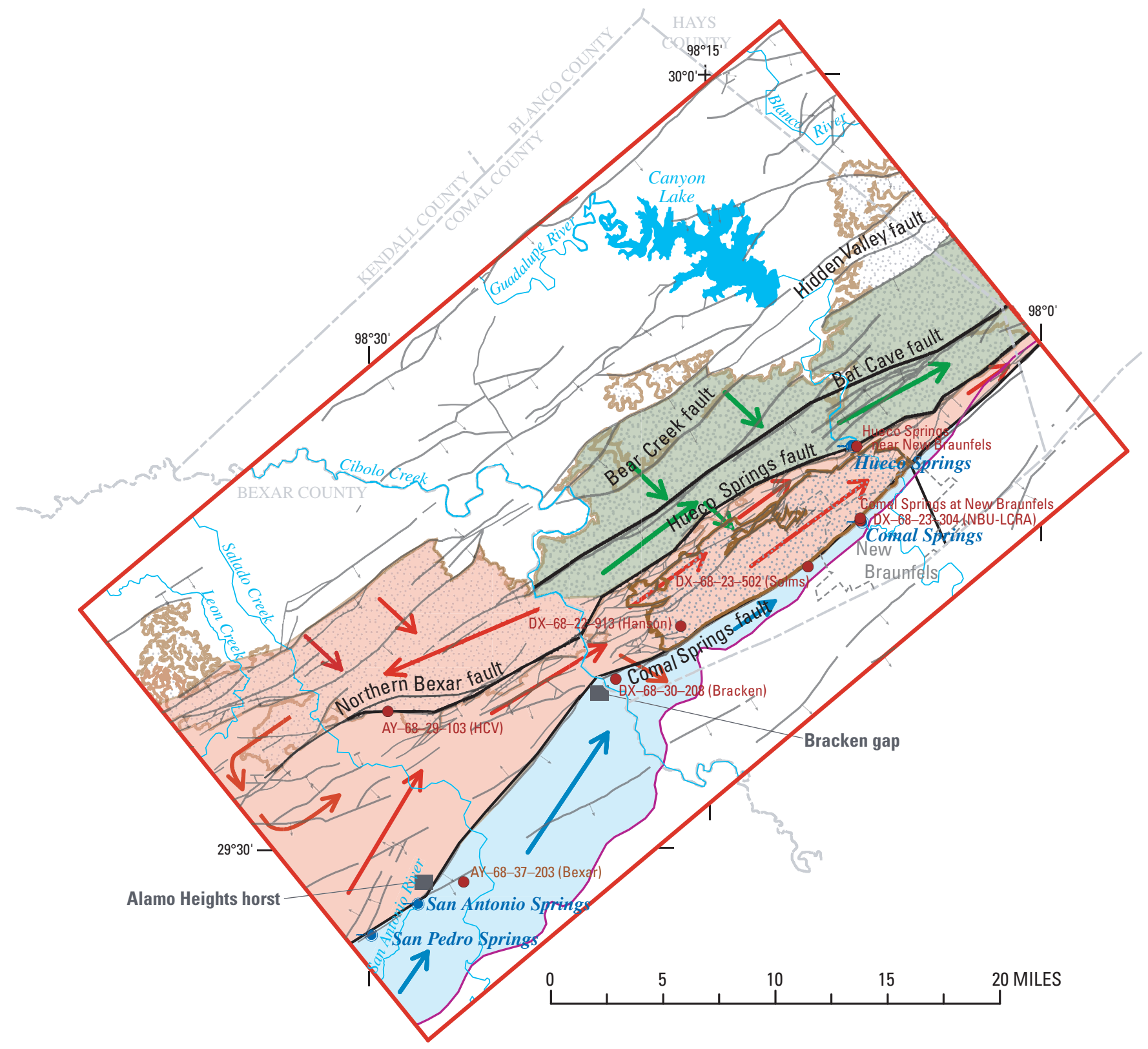

EXPLANATION

$\rightarrow$ Northern Comal flow path and inferred direction of flow

$\rightarrow$ Central Comal flow path and inferred direction of flow

$\longrightarrow$ Southern Comal flow path and inferred direction of flow
$\square$ Edwards aquifer recharge zone (outcrop)

Study area boundary

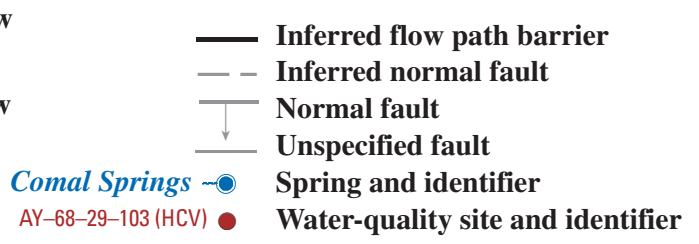
concentration (Schultz, 1994)

Figure 6. Locations of hypothesized ground-water flow paths, northeastern Bexar and southern Comal Counties, Texas. 


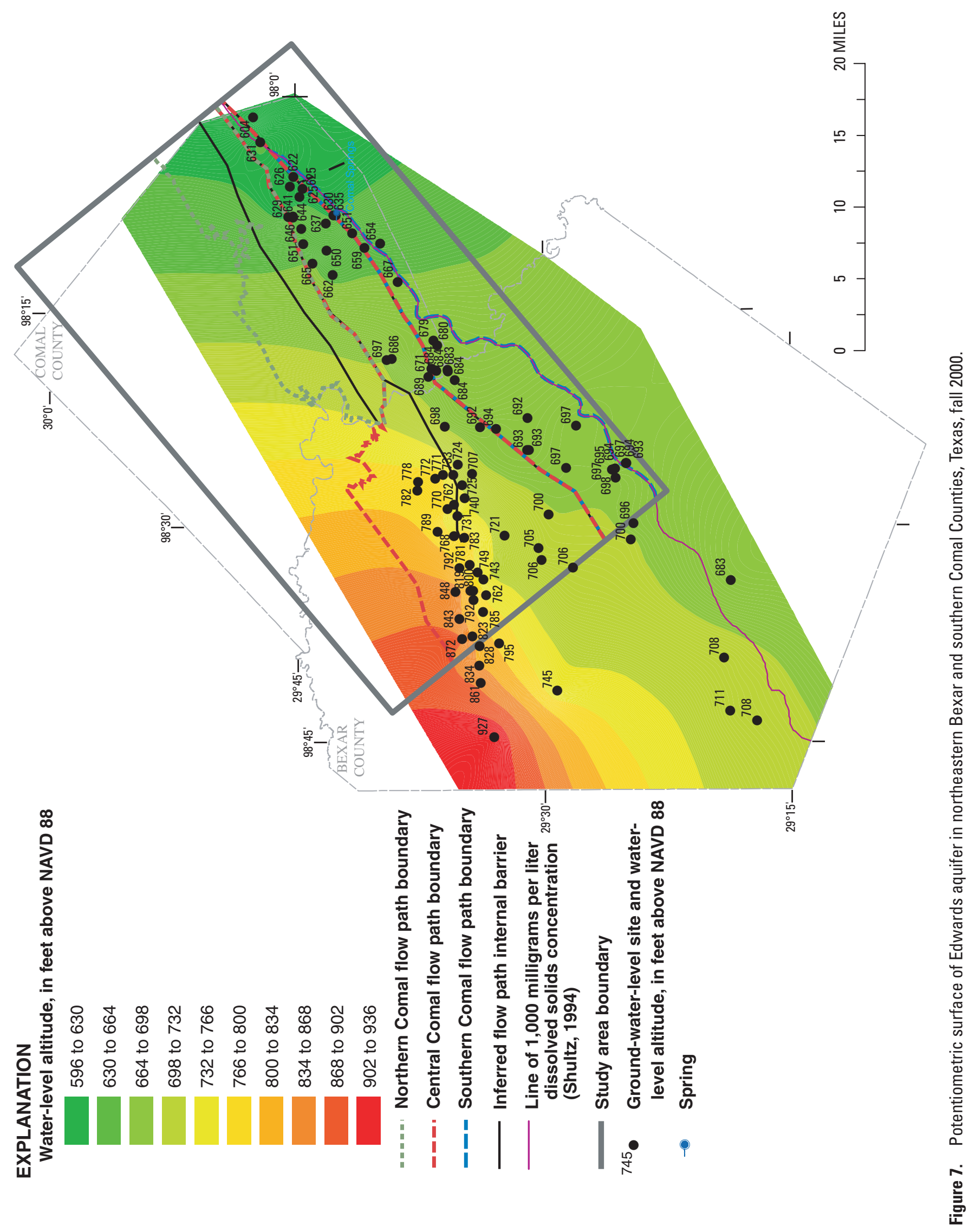




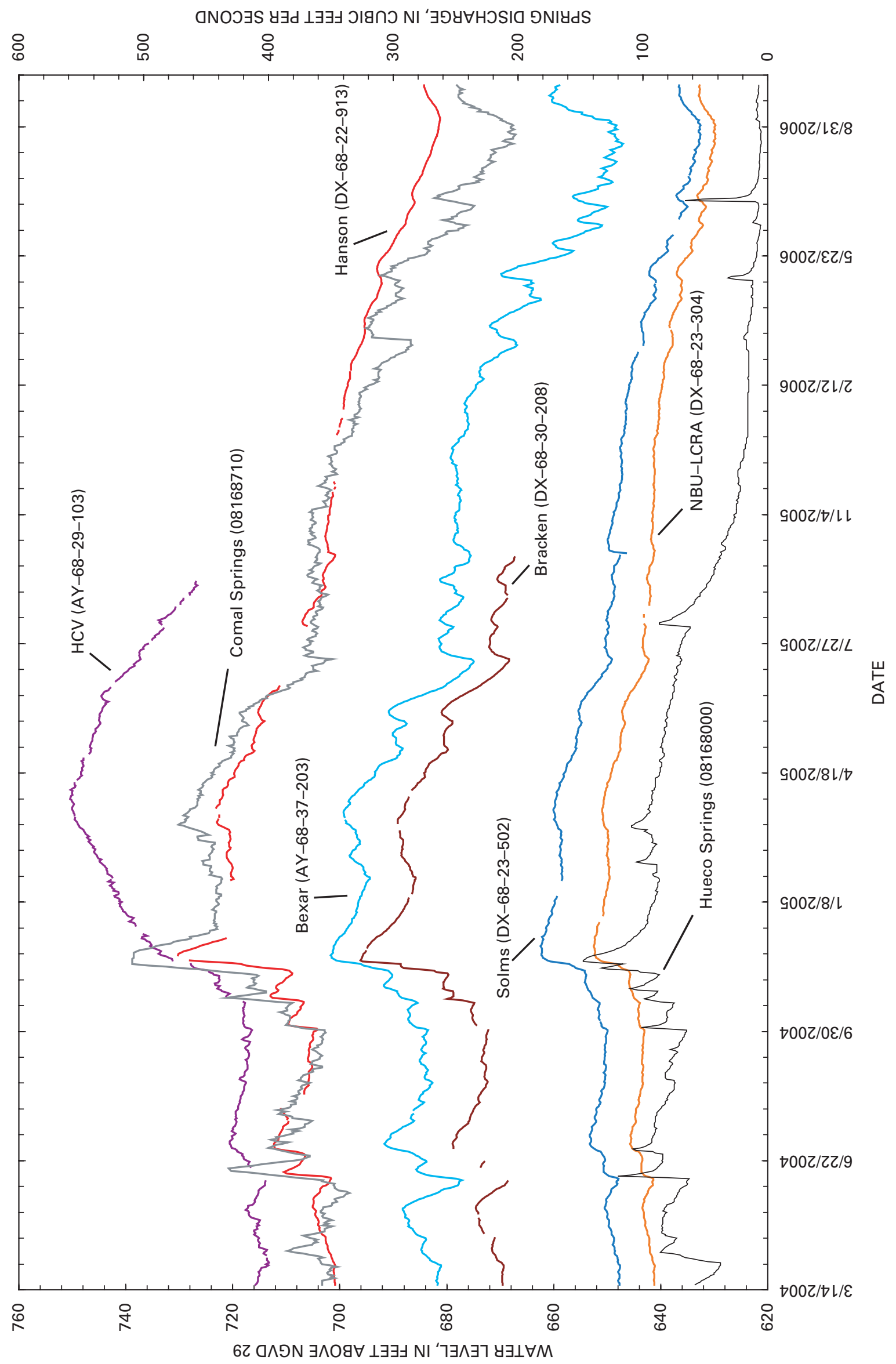

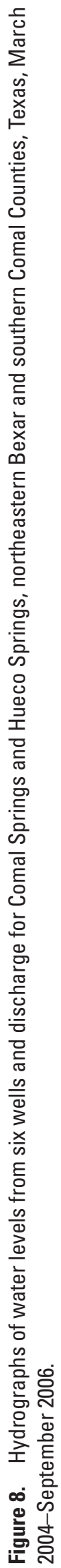




\section{Central Comal Flow Path}

The central Comal flow path (CCFP) (fig. 6) is bounded on the northwest by the Hueco Springs fault and on the southeast by the Comal Springs fault. The potentiometricsurface map indicates that water within the CCFP flows from southwest to northeast (fig. 7). As water moves into central Bexar County from the west it is bifurcated into two flow paths by the Alamo Heights horst (Maclay and Land, 1988) (fig. 6) in the subsurface southwest of the recharge zone in central Bexar County. Water that flows north of the horst becomes constrained northeast of the Comal Springs fault, which completely offsets the Edwards aquifer east of the horst, and becomes flow within the CCFP, whereas water that flows south of the horst becomes flow within the SCFP. Local recharge to the CCFP occurs in northeastern Bexar County as water infiltrates into the Edwards aquifer outcrop northwest of the Northern Bexar fault (fig. 6). The water then moves through the subsurface to the southeast until it encounters the Northern Bexar fault. The Northern Bexar fault acts as a barrier to flow at its northeastern end (Small, 1986, fig. 8), causing water to move to the southwest along the fault trace. The displacement along the Northern Bexar fault decreases southwestward along its trace until it is no longer a barrier to flow (Small, 1986, fig. 9), which allows water to enter the confined section of the aquifer. The local recharge remains north of Comal Springs fault as it merges with the northeastwardmoving water of the horst-induced CCFP. Additional inflow to the CCFP might occur in the subsurface when water from north of the Hueco Springs fault in Comal County crosses over the Hueco Springs fault in areas where the fault fails to fully offset the Edwards aquifer (Small, 1986, figs. 4-5).

As the water in the CCFP continues flowing toward the northeast, structural features in the Edwards aquifer affect the patterns of flow. In eastern Bexar County, the Bracken gap conveys water from the CCFP into the SCFP (fig. 6). Beyond the Bracken gap, the aquifer containing the CCFP is heavily faulted and partially unconfined in the area directly northwest of Comal Springs. In the confined section of the CCFP in this area, the flow is funneled into two hydraulically connected troughs that follow roughly parallel grabens formed in the fault blocks between Comal Springs fault and Hueco Springs fault (fig. 4). The southeastern trough is unconfined at its northeastern end and receives recharge from direct infiltration of rainfall and streamflow losses. The northwestern trough receives subsurface inflow across sections of the Hueco Springs fault that fail to offset the entire thickness of the Edwards aquifer. Although flow within this section of the CCFP is complicated by the complexity of the faulting, in general, much of the water in the northwestern trough likely discharges at Hueco Springs and most of the water in the southeastern trough and in the unconfined sections of the aquifer in the CCFP discharges at springs Comal 1, Comal 2, and Comal 3 at the Comal Springs complex. Water that is not discharged at either Hueco or Comal Springs continues northeastward toward the San Marcos Springs (fig. 1).
Comparison of the water-level hydrographs for wells $\mathrm{HCV}$ and Hanson and discharge hydrographs for Comal Springs and Hueco Springs (fig. 8) provide insight into the movement of ground water in the CCFP. The hydrograph for well HCV shows little, if any, similarity to the hydrographs for well Hanson or either of the springs, indicating a lack of shared flow paths between well HCV and the other sites in the CCFP. Well HCV is in a heavily faulted section of the CCFP that is most likely locally isolated from the rest of the flow path.

Well Hanson is in the unconfined section of the southeastern trough of the CCFP. In general, the hydrograph for well Hanson followed the fluctuation patterns of the discharge hydrographs of Comal Springs and Hueco Springs in number and relative vertical displacement for water levels greater than about 700 feet above NGVD 29. In this area, the regional dense member of the Person Formation within the Edwards aquifer acts as a confining unit. Well Hanson is completed below the regional dense member (approximate altitude 700 feet above NGVD 29). When water levels in well Hanson rose above the regional dense member, the large magnitude of fluctuations in the hydrograph reflected confined properties similar to those at Comal Springs and Hueco Springs. When water levels in well Hanson fell to levels near or below the regional dense member, the Hanson well hydrograph tended to lose much of the vertical displacement and actually resembled the hydrographs of wells Solms and NBU-LCRA. As water levels fell in well Hanson and thus in that section of the CCFP, conditions changed from confined to unconfined. Furthermore, confined flow from the SCFP, under extreme pressure, might have pushed upward across Bracken gap into the CCFP to locally influence water levels in the CCFP.

The Hueco Springs hydrograph (fig. 8) provided evidence that the CCFP might not be the only source of water to the Hueco Springs. An increase in discharge at Hueco Springs in August 2005 had no corresponding increase at Comal Springs, indicating that the pulse of water causing the increased discharge at Hueco Springs either was not sourced in the CCFP or did not reach Comal Springs.

\section{Northern Comal Flow Path}

The northern Comal flow path (NCFP) (fig. 6) is in the Edwards aquifer recharge zone north of Hueco Springs fault and south of Bat Cave fault in Comal County. The potentiometric-surface map indicates that water in the NCFP flows from southwest to northeast (fig. 7). Recharge to the NCFP occurs from direct infiltration of rainfall and streamflow losses to the Edwards aquifer exposed at the surface in the NCFP. Additional inflow likely comes from the Trinity aquifer in the subsurface where the Bat Cave fault juxtaposes the Trinity aquifer against the Edwards aquifer. An undetermined amount of water from the NCFP might flow into the confined sections of the CCFP across Hueco Springs fault in areas where the fault does not completely offset the Edwards aquifer. The 
water remaining north of the Hueco Springs fault flows toward San Marcos Springs.

\section{Correlation of Water Levels}

Statistical correlation between water levels for the six observation wells and spring discharges for Comal Springs and Hueco Springs provides additional evidence for the hypothesized flow paths. Figure 9 graphically demonstrates the relations involving each of the 28 combinations of paired datasets. The Pearson's $r$ correlation coefficient indicates the strength of the linear correlation between dataset pairs and, thus, between water levels or spring discharges, or both. The larger the absolute value of $r$ between -1 and 1 , the stronger the linear correlation. The strongest correlations (r-values ranging from .991 to .999$)$ were observed between the datasets for wells NBU-LCRA and Solms (SCFP) and well Hanson (CCFP), providing evidence for the hydraulic connection between the SCFP and the CCFP across the Bracken gap. The dataset for well Bracken, the well closest to the Bracken gap, is not as strongly correlated with datasets for wells NBU-LCRA, Solms, and Hanson. The well Bracken might be in a less transmissive part of the aquifer than the other three wells, allowing for greater fluctuations in water levels in the well Bracken dataset, which could account for weaker correlations with datasets from those wells. The dataset for well $\mathrm{HCV}$ displayed the weakest correlations with the other datasets, indicating a lack of shared flow paths with water at the other wells, Comal Springs, or Hueco Springs. The dataset for Comal Springs was strongly correlated with those for wells Bexar, NBU-LCRA, Hanson, and Solms (r-values ranging from .961 to .983 ) and fairly strongly correlated with the dataset from well Bracken (r-value of .954). The dataset for Hueco Springs did not correlate linearly with any of the datasets from the other wells or Comal Springs but did have monotonic relations (an increase in one variable corresponds to an increase in the other) with the datasets from wells Bexar, NBU-LCRA, Hanson, and Solms and Comal Springs. One reason for the lack of linear correlation between Hueco Springs and the other Edwards aquifer sites could be the influence of inflow from the Trinity aquifer. In addition, the northwestern trough of the CCFP, which provides most of the flow from the Edwards aquifer to Hueco Springs, could be less hydraulically connected to the rest of the CCFP during periods of low spring discharge than during periods of high spring discharge.

\section{Analysis of Hydrograph Recession Curves}

Hydrographs of discharge from Comal Springs and Hueco Springs were analyzed. Recession curves representing a range of flows were selected from each hydrograph for use in the analyses of hydrograph recession curves. The recession curves were examined for breaks (inflection points) in the recession slope, which are indicative of a change from one flow regime to another within the karst continuum. A reces- sion coefficient $(\alpha)$ was calculated for each section of hydrograph between inflection points using Milanovich's (1981) equation,

$$
\mathrm{Q}_{\mathrm{t}}=\mathrm{Q}_{0} \mathrm{e}^{\alpha\left(\mathrm{t} \mathrm{t}_{0}\right)},
$$

where $\mathrm{Q}_{0}$ is the initial discharge at time $\mathrm{t}_{0}$, the beginning of each recession slope, and $Q_{t}$ is the discharge at time t. Solving for $\alpha$ yields the equation

$$
\alpha=\frac{\ln \left(\mathrm{Q}_{\mathrm{t}} / \mathrm{Q}_{0}\right)}{\left(\mathrm{t}-\mathrm{t}_{0}\right)} .
$$

For the hydrographs of this study (fig. 9), an $\alpha$ of about 0.18 , corresponding to a steep (nearly vertical) slope, indicates conduit-driven drainage of a karst aquifer. An $\alpha$ of about 0.008 , corresponding to a more horizontal slope, indicates the diffuse drainage of the primary porosity in the matrix of the aquifer. An $\alpha$ of about $0.02-0.09$, corresponding to an intermediate slope, can indicate either drainage of the fractures in the aquifer or a mixture of conduit and diffuse drainage.

Figure 10 illustrates discharge magnitude and variability for Comal Springs and Hueco Springs from mid-March 2004 through August 2006. Comal Springs discharge was consistently greater and more variable than discharge at Hueco Springs. In general, increases in discharge at Hueco Springs were smaller and shorter in duration than increases at Comal Springs.

Discharge-recession curves for Comal Springs were used to identify the flow regimes in the aquifer contributing to the springs. Flow varied from 202 to 509 cubic feet per second $\left(\mathrm{ft}^{3} / \mathrm{s}\right)$ during 2004-06 with the highest discharges occurring during November 21-25, 2004. The recession curve for the highest-discharge period indicates that fracture flow, or a mixture of conduit flow and diffuse flow, first dominated the ground-water system supplying water to the springs, followed by conduit flow and then fracture flow, or a mixture of conduit and diffuse flow, again. This pattern indicates that, during periods of high-discharge recession at the Comal Springs complex, the ground-water system supplying the springs might include upper and lower layers of the aquifer dominated by fractures or a mixture of conduits and aquifer matrix, with a middle section of the aquifer dominated by conduits. The lowest discharges occurred near the end of the study period (August 2006). During the lowest-discharge period, July 2005-August 2006, the recession curves for Comal Springs discharge reflected mostly an $\alpha$ of about 0.09 , indicating fracture flow or a mixture of conduit and diffuse flow. The majority of the recession slopes for the Comal Springs hydrograph for the 2-year period had an $\alpha$ of about 0.09 , indicating that the overall flow through the aquifer to Comal Springs is fracture flow or a mixture of conduit and diffuse flow. During the 2-year period, $\alpha$ values less than 0.02 were not observed for Comal Springs, indicating that diffuse flow never dominated the flow system supplying Comal Springs. 


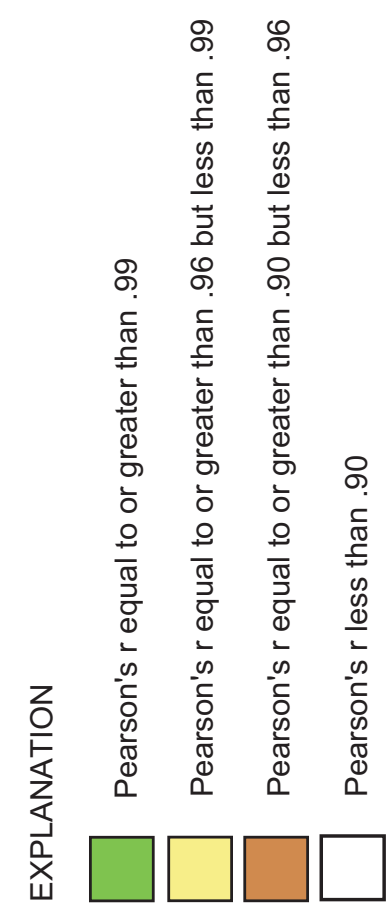

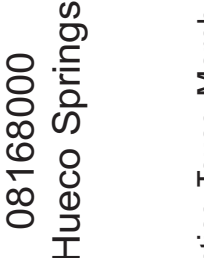

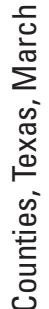
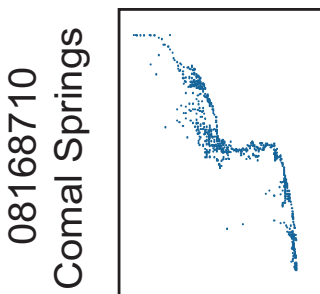

ㅇํํ
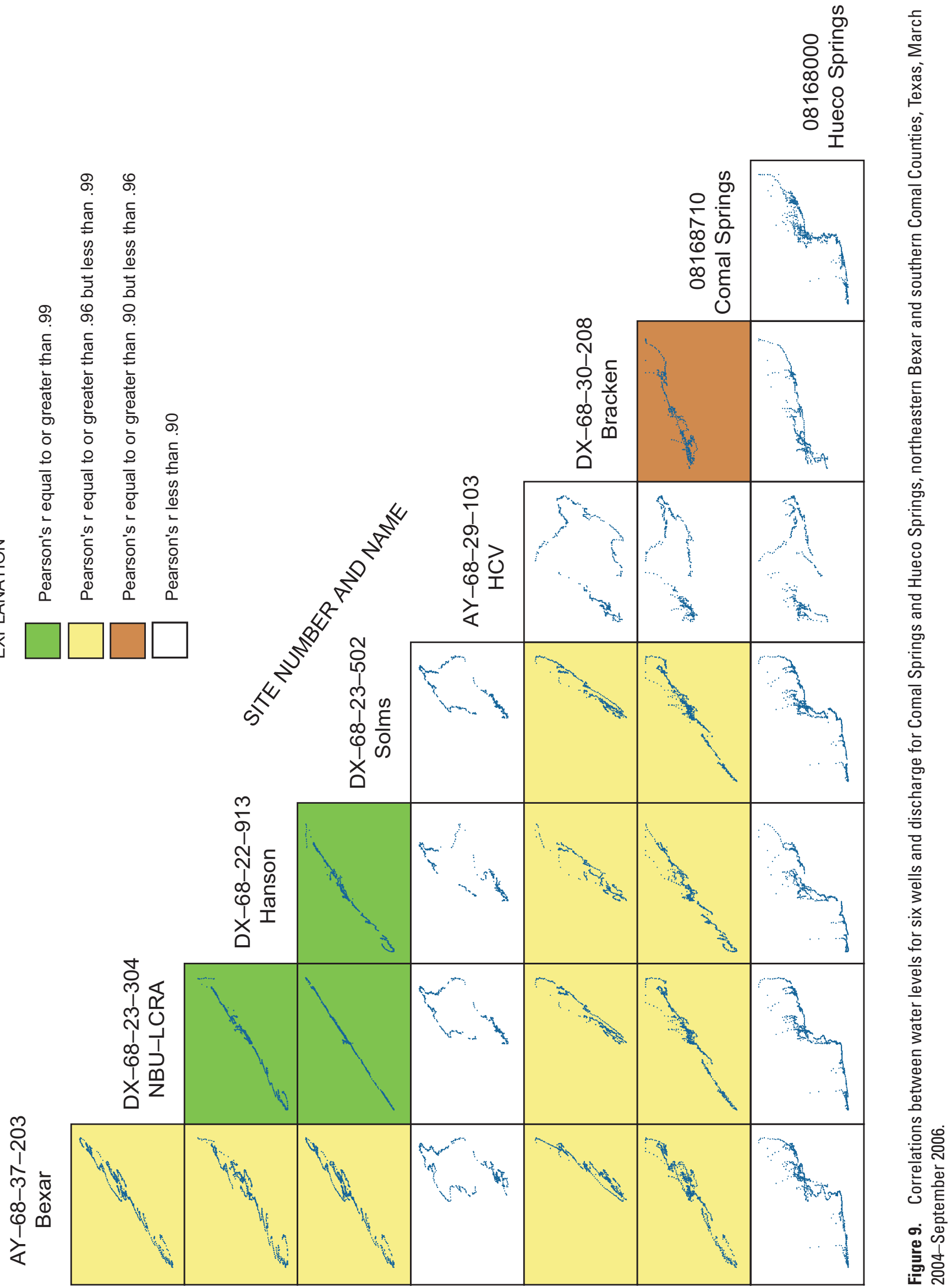


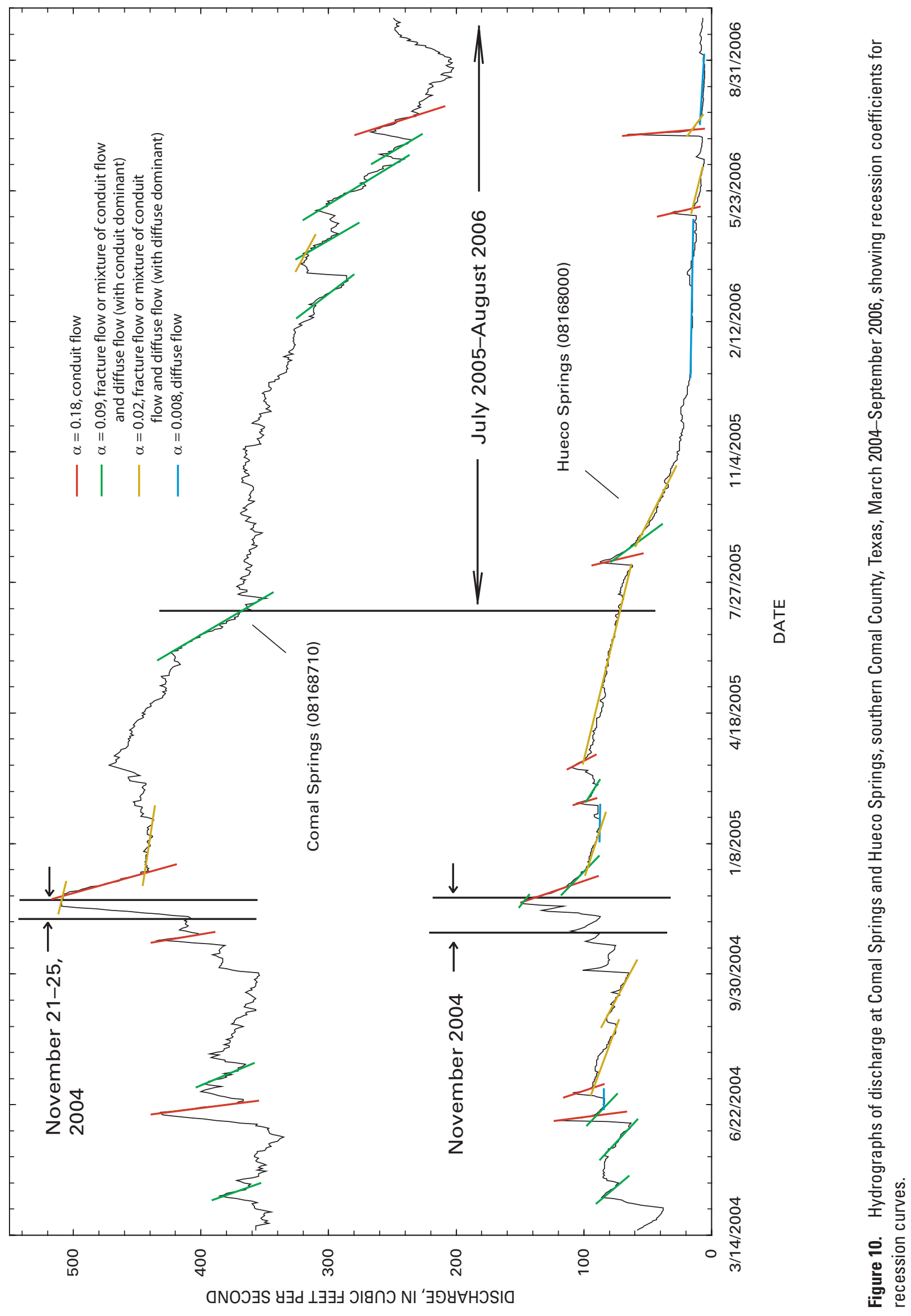


Discharge-recession curves for Hueco Springs were analyzed to identify the flow regimes in the aquifer contributing to the springs and to attempt to obtain additional evidence of contribution from the Trinity aquifer. Flow at Hueco Springs varied from 5.3 to $148 \mathrm{ft}^{3} / \mathrm{s}$ during 2004-06 with the highest discharges occurring during November 2004. The recession curve for the highest-discharge period indicates that fracture flow or a mixture of conduit and diffuse flow first dominated the ground-water system supplying water to the springs. Following this period of fracture or mixed drainage, conduit flow controlled the release of water to the springs, followed by another period of fracture or mixed flow. The second period of fracture or mixed drainage was followed by periods in which diffuse flow became increasingly dominant and eventually prevailed. The lowest discharges occurred near the end of the study period (August 2006). During the lowest-discharge period, July 2005-August 2006, the increases in discharge at Hueco Springs were characterized by sudden high increases with recession curves that were dominated by conduit flow followed by fracture or conduit/diffuse mixed flow and ending with diffuse flow. During 2004-06, the recession slopes with an $\alpha$ of about 0.18 represented the greatest number of slopes for the Hueco Springs hydrograph, indicating that initial drainage of the aquifer to Hueco Springs following a recharge event is dominated by a fast-draining conduit system. Following the drainage of the conduits, the system typically is characterized by either fracture flow or a mixture of conduit and diffuse flow, or diffuse flow.

Although the Comal Springs complex and Hueco Springs are only about 3 miles apart, the hydrograph recession slope analysis for the two springs reinforces the fact that the springs are sourced from a complex karst system. The initial recession slopes for Comal Springs predominately represent a mixture of conduit and fracture flow, or a mixture of conduit and diffuse flow, whereas the initial recession slopes for Hueco Springs predominately represent conduit flow. The initial mixed flow from Comal Springs likely represents the conduit flow contribution from the SCFP, which provides most of the flow from the springs, and the fracture flow contribution from the CCFP. The initial conduit flow from Hueco Springs provides evidence that the northwestern trough within the CCFP in Comal County might be highly transmissive, allowing for rapid movement of water through the aquifer to Hueco Springs.

\section{Geochemical Identification of Flow Paths}

\section{Major-Ion Chemistry}

Trilinear diagrams constructed using major-ion chemistry from samples collected at wells in and springs emerging from the SCFP, CCFP, and NCFP (fig. 11) indicate that all three flow paths are dominated by calcium-bicarbonate type water. Relatively little variation in major-ion chemistry was observed. The water samples from wells and springs in the CCFP showed more variability in major-ion chemistry than those from the two other flow paths. The samples from wells in the NCFP consistently had higher percentages of bicarbonate and lower percentages of sulfate and chloride than the samples collected from sites in the SCFP. The comparatively high sulfate and chloride concentrations in the SCFP samples might indicate that the water in the flow path was mixing with small amounts of saline water from the freshwater/saline-water transition zone.

A graph of the relation between calcium concentration and the ratio of magnesium to calcium concentrations provided further evidence for the hypothesized flow paths (fig. 12). Samples from wells in the SCFP generally yielded low calcium concentrations coupled with moderate $\mathrm{Mg} / \mathrm{Ca}$ ratios (thus moderate magnesium concentrations). The highest calcium concentrations and lowest $\mathrm{Mg} / \mathrm{Ca}$ ratios (contributed to by low magnesium concentrations) were in samples collected from the CCFP. The samples from the CCFP yielded data points that plotted in a grouping overlapping the data points for the SCFP. The high concentrations of magnesium in the samples collected from the recharge zone in Comal County (NCFP) might be evidence that water from the Trinity aquifer is entering the Edwards aquifer in the subsurface. The calcium concentration of water from Hueco Springs was lower when the spring discharge was low than when the spring discharge was high, indicating that during periods of low discharge Hueco Springs might receive a larger contribution from the Trinity aquifer than during periods of high discharge.

\section{Stable Isotopes}

The relation between $\delta \mathrm{D}$ and $\delta^{18} \mathrm{O}$ in water samples from the Edwards aquifer, by flow path, is shown in figure 13 . The graph shows that, except for samples collected from wells in the Edwards aquifer recharge zone in northeastern Bexar County (CCFP) following an unusually intense rain storm produced by a tropical system in October 1998, there was not much variation in stable isotope values among the flow paths. In the study area $\delta \mathrm{D}$ in ground water ranged from -36.00 per mil (well AY-68-28-313 in the CCFP) to -20.89 per mil (well DX-68-23-620 in the SCFP) and $\delta^{18} \mathrm{O}$ ranged from -6.03 per mil (well AY-68-28-313 in the CCFP) to -3.70 per mil (spring Hueco A in the CCFP). Excluding ground-water samples collected from wells in the recharge zone of northeastern Bexar County following the October 1998 storm, the $\delta \mathrm{D}$ range in the study area was -33.00 to -20.89 per mil and the $\delta^{18} \mathrm{O}$ range was -4.60 to -3.70 per mil.

The local meteoric water line (LMWL; $\delta \mathrm{D}=8.8032$ $\left.\delta^{18} \mathrm{O}+17.825\right)$ was calculated using rainfall isotope data collected in the study area. All ground-water samples, except one, plotted below the LMWL. The plotting positions indicate that the water evaporated, to varying degrees, before entering the aquifer as recharge. 

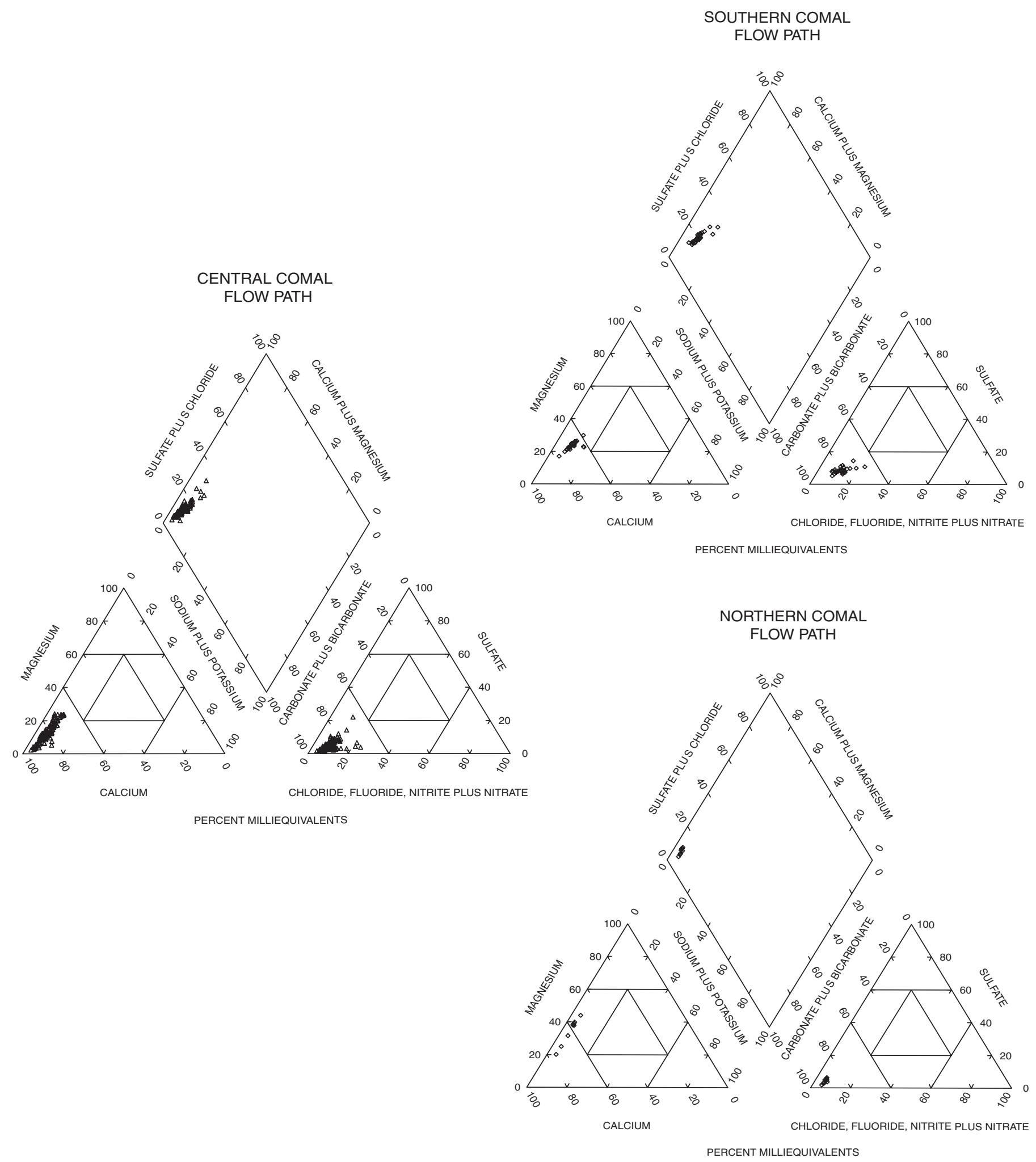

Figure 11. Trilinear diagrams showing composition of ground water in the Edwards aquifer in the southern, central, and northern Comal flow paths, northeastern Bexar and southern Comal Counties, Texas. 


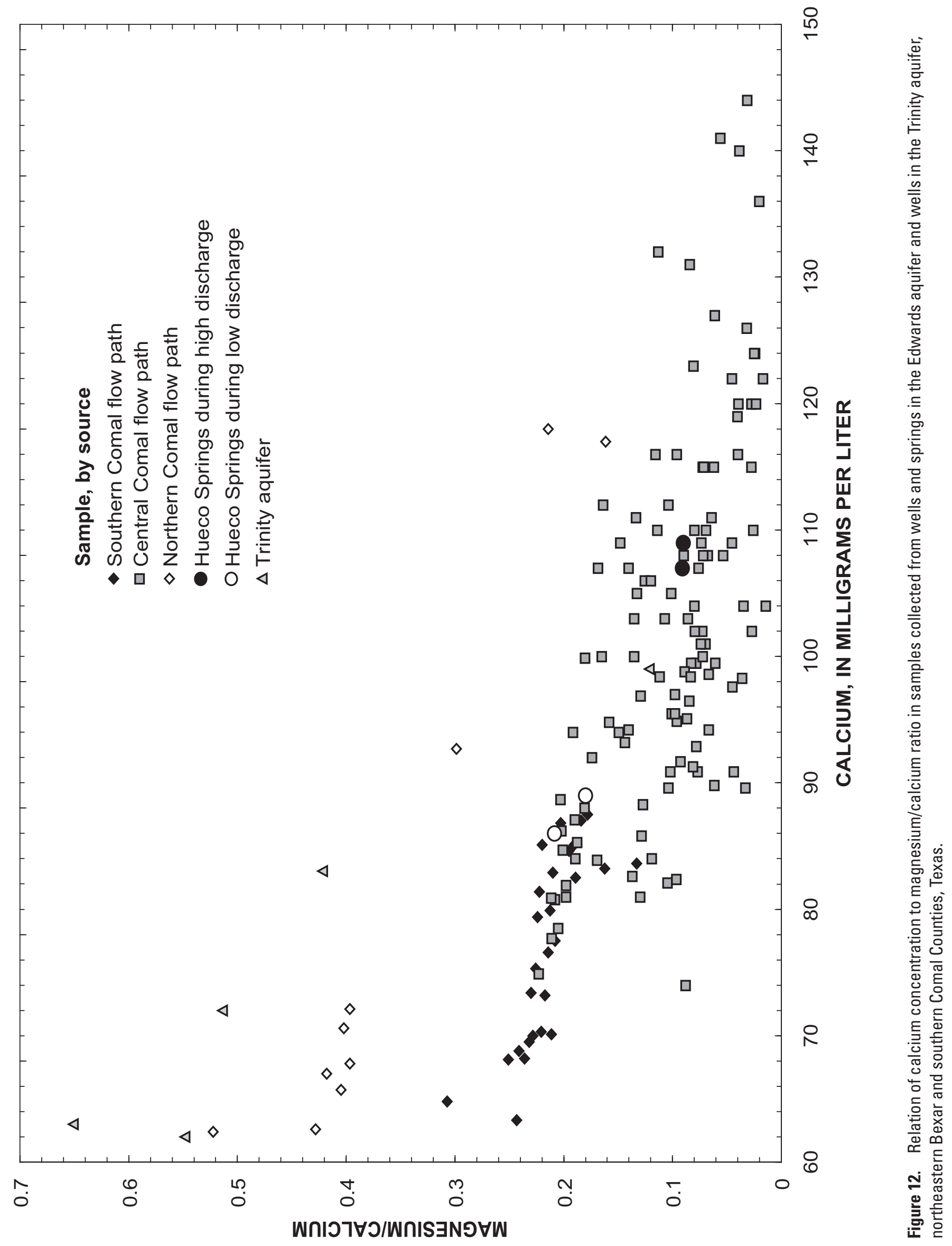




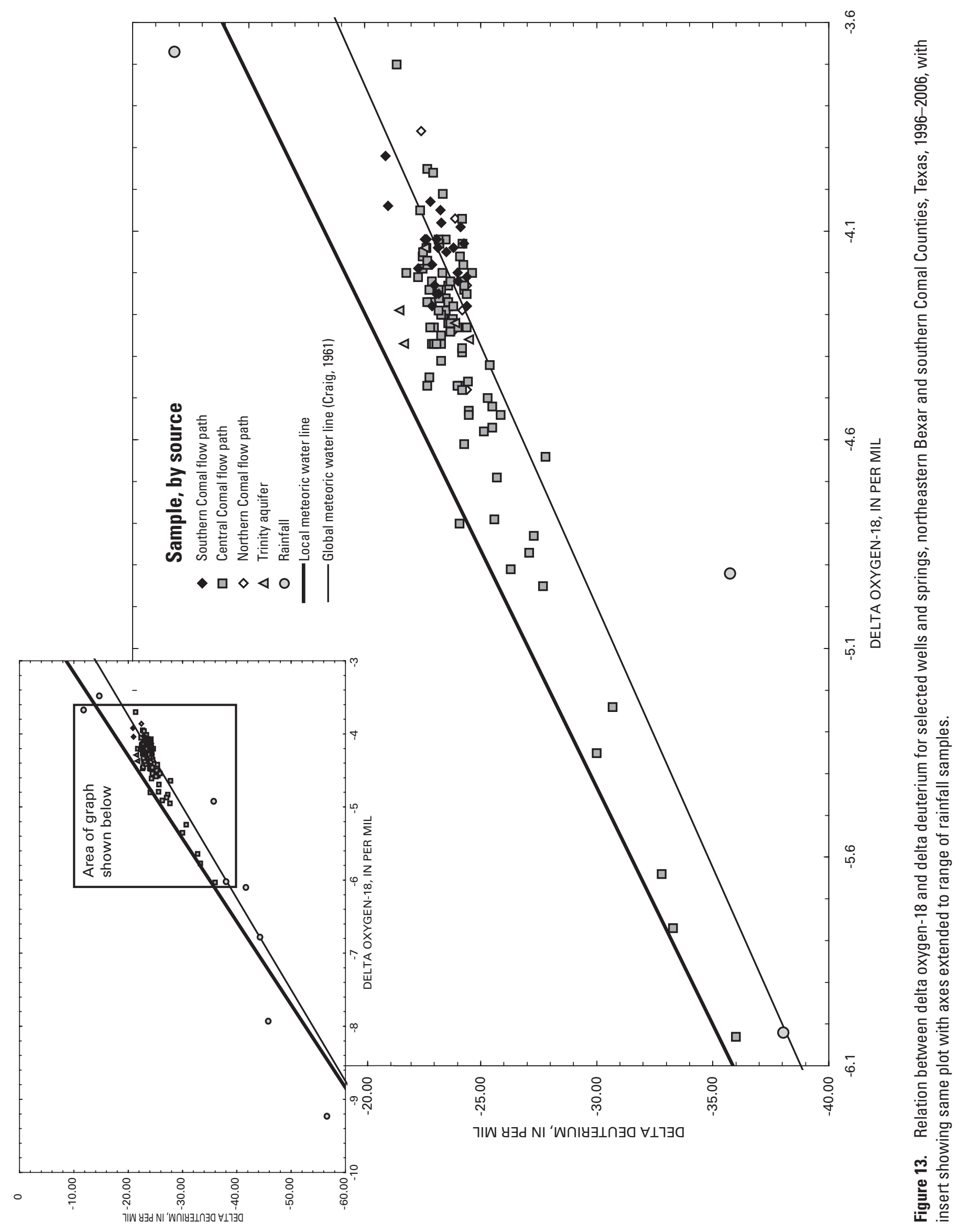


Samples collected from wells and springs in the SCFP plotted in a relatively small area on the graph (fig. 13) with $\delta D$ values ranging from -24.40 to -20.89 per mil and $\delta^{18} \mathrm{O}$ values ranging from -4.28 to -3.92 per mil. The largest range in isotopic composition was observed in samples collected from the CCFP, with $\delta \mathrm{D}$ values ranging from -36.00 to -21.39 per mil and $\delta^{18} \mathrm{O}$ values ranging from -6.03 to -3.70 per mil. CCFP samples with $\delta \mathrm{D}$ values greater than about -4.3 per mil overlap the grouping of SCFP samples. The samples from wells in the NCFP plot in a narrow area that spans the area occupied by the SCFP samples with $\delta \mathrm{D}$ values ranging from -24.40 to -22.44 per mil and $\delta^{18} \mathrm{O}$ values ranging values ranging from -4.48 to -3.86 per mil.

\section{Ground-Water Ages}

Apparent ages of ground water in samples collected in 2003 derived from $\mathrm{SF}_{6}$ analysis (fig. 14) ranged from about 21 years in well DX-68-23-104 in the NCFP to present day (less than 0.5 year or recharged in 2003) at spring Comal 7 in the SCFP. Ages ranged from about 17 years (well AY-68-29-914) to present day (spring Comal 7) in the SCFP, with the oldest water in the upgradient section of the SCFP and the youngest water from a spring at the downgradient end of the SCFP. The young apparent age of the Comal 7 spring might be evidence that young water from the upthrown block of Comal Springs fault is supplying additional recharge to the spring. The $\mathrm{SF}_{6}$ method of age dating water does not take into account the mixing of young and old waters and, therefore, reflects the age of the young water. In the CCFP, ages ranged from about 16 years (well DX-68-22-810) to about 1 year (well DX-68-30-111), with both the oldest and youngest water in the upgradient section of the flow path. Water in the NCFP likely receives inflow from the subsurface as a result of inter-aquifer hydraulic connection with the Trinity aquifer, which has substantially lower transmissivity (thus, possibly water of older apparent age) than does the Edwards aquifer. The apparent age of the water in well DX-68-23-104 might reflect the influence of the Trinity aquifer on the NCFP.

The apparent ages of the samples collected in 2003 from the various orifices of the Comal Springs complex and Hueco Springs, computed using $\mathrm{SF}_{6}$ analysis, provide evidence of the complex nature of the karst aquifer in which the springs are sourced. The samples from the orifices at the Comal Springs complex range in age from about 6 years to present day (less than 0.5 year or recharged in 2003). The samples from Hueco Springs provided ages that range from about 7 to 8 years. The recent ages observed from the orifices at Comal Springs indicate an inflow of water near the springs complex, possibly from the unconfined section of the Edwards aquifer at the northeastern end of the southeastern trough of the CCFP in Comaal County. The relatively old water at Hueco Springs indicates a possible inflow of water into the ground-water system supplying the springs from a source of water yielding relatively older water than the Edwards aquifer, possibly the Trinity aquifer.

Apparent ages of ground-water samples collected in 2003 derived from ${ }^{3} \mathrm{H} /{ }^{3} \mathrm{He}$ analysis (fig. 15) ranged from greater than 45 years in well DX-68-23-104 in the NCFP to present day (less than 0.5 year or recharged in 2003) in well DX-68-22-810 in the CCFP. Ages ranged from 21.3 to 8.8 years in the SCFP. In general, the samples from wells in Bexar County (upgradient section of the SCFP) showed younger ages than wells and springs in the downgradient section of the SCFP. The samples from a spring in the Comal Spring complex, Spring Island, indicated ages similar to those for samples from the wells in Bexar County. A possible explanation for the anomalously young age of water in the Comal Springs complex is that there is a local source for the spring. Well DX-68-23-602 in the SCFP had a younger age than the wells in Bexar County. This well is on the escarpment formed along the Comal Springs fault and might be receiving inflow from the unconfined CCFP on the upthrown side of the fault. In the CCFP, ages ranged from 17.3 years to present day (less than 0.5 year or recharged in 2003) with the oldest water in well AY-68-30-520 near the Bexar-Comal County line in the central section of the flow path and the youngest water in the central section of the flow path where the Edwards aquifer is exposed, allowing recharge from infiltration of rainfall and streamflow losses to occur. The data from samples collected at Hueco Springs indicate very young water (apparent age less than 0.5 year) mixed with very old water. The oldest water was in well DX-68-23-104 in the NCFP. Water in this well is tritium depleted, indicating that the water has undergone complete tritium decay. The apparent age of the water is not attainable by the ${ }^{3} \mathrm{H} /{ }^{3} \mathrm{He}$ method, but based on the tritium decay rate the water is estimated to have been recharged more than 45 years ago. A possible source for this old water could be inflow from the underlying Trinity aquifer.

Apparent ages for ground-water samples collected in 2006 ranged from 41.1 years at spring Comal 7 in the SCFP to present day (less than 0.5 year or recharged in 2006) in wells DX-68-23-710 and DX-68-22-905 in the CCFP (fig. 15). In general, samples collected in 2003 yielded younger apparent ages than samples collected during 2006. Water levels in the Edwards aquifer were higher during the sampling in 2003 than they were during the sampling period in 2006, likely resulting in faster flow rates in the aquifer because of increased hydraulic gradients. Many of the samples contained a mixture of young and old water, especially those collected from areas near the downgradient ends of the flow paths. The samples collected from Hueco Springs in 2006, like those collected in 2003 , showed a mixture of very young water (apparent age less than 0.5 year) with very old water (possibly sourced from the Trinity aquifer). 


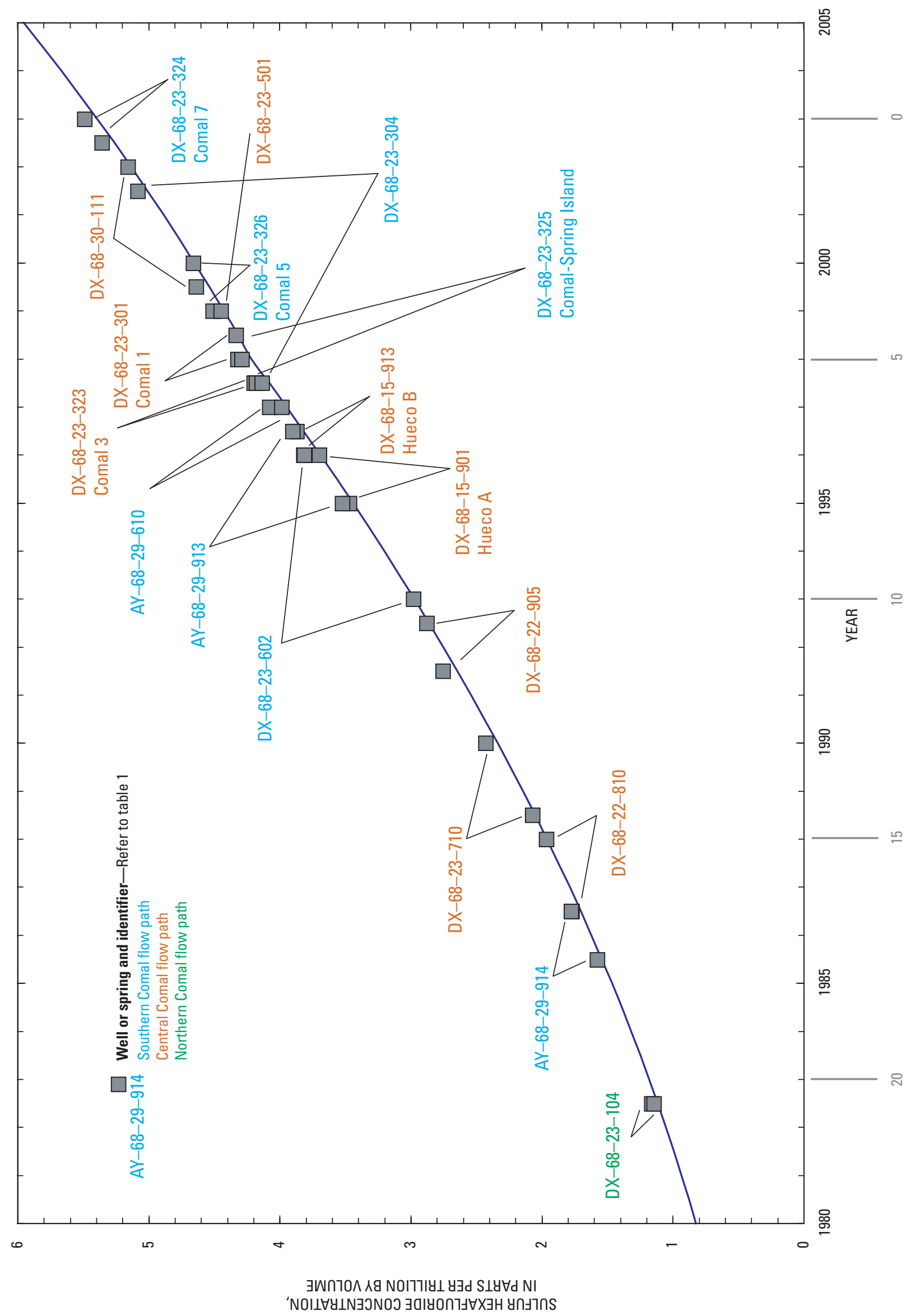

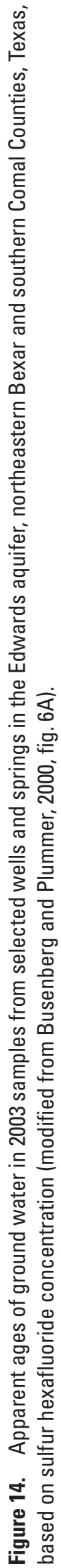


Sample year 2003

\section{EXPLANATION}

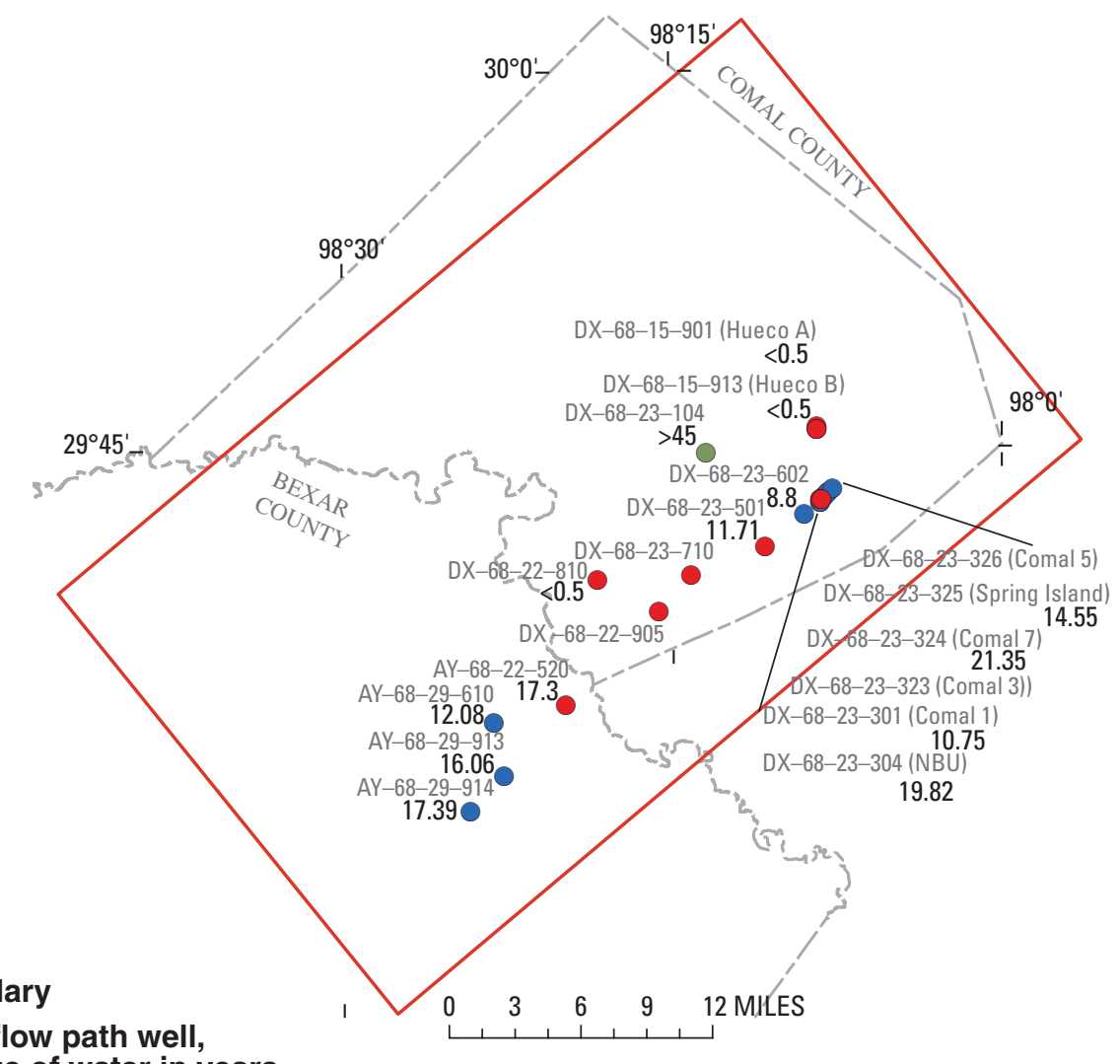
AY-68-29-913 16.06

Study area boundary

Southern Comal flow path well, identifier, and age of water in years

DX-68-23-501 Central Comal flow path well,

11.71 identifier, and age of water in years

DX-68-23-104 Northern Comal flow path well, $>45$

\section{identifier, and age of water in years}

$>\quad=$ greater than

$<\quad=$ less than

\section{Sample year 2006}

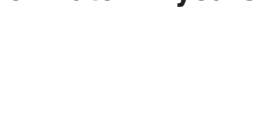




\section{Summary}

The U.S. Geological Survey (USGS), in cooperation with the San Antonio Water System, conducted a 4-year study during 2002-06 to identify major flow paths in the Edwards aquifer in northeastern Bexar and southern Comal Counties (study area). Geologic structure, surface- and ground-water data, and geochemistry were used to identify flow paths. Knowledge of geologic structure and previous flow path analyses conducted by the USGS provided a basis for the initial selection of hypothesized flow paths in the study area.

Historical and new data were used in analyses. Continuous water-level data were collected at six observation wells from mid-March 2004 through September 2006. Discharge data were obtained from two springflow sites for the same time period. Ground-water chemistry and isotope data were compiled from samples collected from 76 wells and nine springs (and spring orifices of major springs) during 19962006. Isotope data also were obtained from samples collected at four rainfall-sampling sites during 1998-2003.

The southern Comal flow path (SCFP) is bounded on the northwest by the Comal Springs fault and on the southeast by the freshwater/saline-water transition zone in the Edwards aquifer. Most of the water in this flow path enters the aquifer west of the study area. Additional inflows occur as spillover from north of the Comal Springs fault at the Bracken gap, an area near the Bexar-Comal-Guadalupe County line intersection where the fault has not completely offset the entire aquifer thickness. The SCFP gradually narrows as it nears Comal Springs because saline water encroaches as the freshwater is discharged at the springs.

The central Comal flow path (CCFP) is bounded on the northwest by the Hueco Springs fault and on the southeast by the Comal Springs fault. Water that is diverted north by the Alamo Heights horst in central Bexar County flows north of Comal Springs fault, accounting for the regional source to this flow path. Local recharge from infiltration of rainfall and streamflow leakage is supplied to the flow path from the Edwards aquifer recharge zone in northeastern Bexar County. These mixed waters then flow northeast through a highly fractured and faulted section of the aquifer. The complex faulting produces a hydraulically connected, two-trough system in the aquifer that is confined in some areas and unconfined in others. The troughs channel flow to discharge points at both Comal Springs and Hueco Springs. Water that does not discharge at either of the springs continues flowing northeastward toward San Marcos Springs.

The northern Comal flow path (NCFP) is in the Edwards aquifer recharge zone in Comal County and is bounded on the north by the Bat Cave fault and on the south by the Hueco Springs fault. Recharge to this flow path occurs from the Edwards aquifer recharge zone northwest of Bat Cave fault in Comal County from direct infiltration of rainfall and streamflow losses to the Edwards aquifer exposed at the surface. Additional inflow likely comes from the Trinity aquifer in the subsurface where the Bat Cave fault juxtaposes the Trinity aquifer against the Edwards aquifer. Flow also might occur between the CCFP and the NCFP in central Comal County through a section of the Hueco Springs fault that does not completely offset the entire thickness of the Edwards aquifer.

A potentiometric-surface map derived from synoptic water-level measurements made in fall 2000 was used to identify the generally southwest to northeast flow directions within the flow paths. Statistical correlations between water levels for six observation wells and discharges from Comal Springs and Hueco Springs (28 combinations of paired datasets) yielded additional evidence for the hypothesized flow paths. Strong linear correlations were evident between the datasets from wells and springs within the same hypothesized flow path and the datasets from wells in areas where flow between flow paths was suspected.

Hydrograph recession slope analysis for Comal and Hueco Springs reinforces the fact that the springs are sourced from a complex karst system. The initial recession slopes for Comal Springs predominately represent a mixture of conduit and fracture flow, or a mixture of conduit and diffuse flow, whereas the initial recession slopes for Hueco Springs predominately represent conduit flow. The initial mixed flow from Comal Springs likely represents the conduit flow contribution from the SCFP, which provides most of the flow from the springs, and the fracture flow contribution from the CCFP. The initial conduit flow from Hueco Springs provides evidence that the northwestern trough within the CCFP in Comal County might be highly transmissive, allowing for rapid movement of water through the aquifer to Hueco Springs.

Geochemical data (major ions, stable isotopes, sulfur hexafluoride, and tritium and helium) were used in graphical analyses to obtain evidence of the flow path from which wells or springs derive water. Major-ion geochemistry in samples from selected wells and springs showed relatively little variation. Samples from the SCFP were characterized by relatively high sulfate and chloride concentrations possibly indicating that the water in the flow path was mixing with small amounts of saline water from the freshwater/saline-water transition zone. Samples from the CCFP yielded the most varied majorion geochemistry of the three hypothesized flow paths. CCFP samples were characterized, in general, by high calcium concentrations and low magnesium concentrations. Samples from the NCFP were characterized by relatively low sulfate and chloride concentrations and high magnesium concentrations. The high magnesium concentrations characteristic of NCFP samples from the recharge zone in Comal County might indicate water from the Trinity aquifer is entering the Edwards aquifer in the subsurface.

A graph of the relation between the stable isotopes $\delta \mathrm{D}$ and $\delta^{18} \mathrm{O}$ showed that, except for samples collected from wells in the Edwards aquifer recharge zone in northeastern Bexar County following an unusually intense rain storm produced by a tropical system, there was not much variation in stable isotope values among the flow paths. In the study area $\delta \mathrm{D}$ in ground water ranged from -36.00 to -20.89 per mil and $\delta^{18} \mathrm{O}$ 
ranged from -6.03 to -3.70 per mil. Excluding samples collected from wells in the recharge zone of northeastern Bexar County following the intense rain storm, the $\delta \mathrm{D}$ range in the study area was -33.00 to -20.89 per mil and the $\delta^{18} \mathrm{O}$ range was -4.60 to -3.70 per mil.

Two ground-water age-dating techniques, sulfur hexafluoride concentrations and tritium-helium-3 isotope ratios, were used to compute apparent ages (time since recharge occurred) of water samples collected from wells and springs in the study area. In general, the apparent ages computed by the two methods do not seem to indicate direction of flow. Apparent ages computed for water samples in northeastern Bexar and southern Comal Counties do not vary greatly except for some very young water in central Comal County. Additional recharge from direct infiltration of precipitation and streamflow losses into the exposed Edwards aquifer in central Comal County might account for younger age dates in the middle section of the CCFP.

\section{References}

American Public Health Association, 1998, Standard methods for the examination of water and wastewater (20th ed.): Washington, D.C., American Public Health Association, American Water Works Association, and Water Environment Federation, p. 3-37-3-43.

Baedke, S.J., and Krothe, N.C., 2001, Derivation of effective hydraulic parameters of a karst aquifer from discharge hydrograph analysis: Water Resources Research, v. 37, no. 1, p. 13-19.

Barker, R.A., and Ardis, A.F., 1996, Hydrogeologic framework of the Edwards-Trinity aquifer system, west-central Texas: U.S. Geological Survey Professional Paper 1421-B, $61 \mathrm{p}$.

Bonacci, O., 1993, Karst springs hydrographs as indicators of karst aquifers: Hydrological Sciences-Journal-des Sciences Hydrologiques, v. 33, no. 1, p. 51-62.

Busenberg, Eyrybaides, and Plummer, L.N., 2000, Dating young groundwater with sulfur hexafluoride-Natural and anthropogenic sources of sulfur hexafluoride: Water Resources Research, v. 36, no. 10, p. 3,011-3,030.

Craig, H., 1961, Isotopic variation in meteoric water: Science, v. 133, p. $1,702-1,703$.

Edwards Aquifer Authority, 2007, Edwards aquifer optimization program/reports: accessed December 5, 2007, at http:// www.edwardsaquifer.org/pages/research_optimization.htm

Faires, L.M., 1993, Methods of analysis by the U.S. Geological Survey National Water Quality Laboratory-Determination of metals in water by inductively coupled plasma-mass spectrometry: U.S. Geological Survey Open-File Report 92-634, 28 p.
Fishman, M.J., and Friedman, L.C., 1989, Methods for determination of inorganic substances in water and fluvial sediments: U.S. Geological Survey Techniques of WaterResources Investigations, book 5, chap. A1, 545 p.

Fishman, M.J., ed., 1993, Methods of analysis by the U.S. Geological Survey National Water Quality LaboratoryDetermination of inorganic and organic constituents in water and fluvial sediments: U.S. Geological Survey OpenFile Report 93-125, 217 p.

Garbarino, J.R., Kanagy, L.K., and Cree, M.E., 2006, Determination of elements in natural-water, biota, sediment and soil samples using collision/reaction cell inductively coupled plasma-mass spectrometry: U.S. Geological Survey Techniques and Methods, book 5, sec. B, chap. 1, 88 p.

Groschen, G.E., 1994, Analysis of data from test-well sites along the downdip limit of freshwater in the Edwards aquifer, San Antonio, Texas, 1985-87: U.S. Geological Survey Water-Resources Investigations Report 93-4100, 92 p.

Groschen, G.E., 1996, Hydrogeologic factors that affect the flowpath of water in selected zones of the Edwards aquifer, San Antonio region, Texas: U.S. Geological Survey WaterResources Investigations Report 96-4046, 73 p.

Hamilton, J.M., and Schindel, G.M., 2006, Edwards Aquifer Authority synoptic water level program 1999-2004 report: Edwards Aquifer Authority Report No. 06-02, 97 p.

Helsel, D.R., and Hirsch, R.M., 1995, Statistical methods in water resources-Studies in environmental science 49: New York, Elsevier, 529 p.

Hem, J.D., 1992, Study and interpretation of the chemical characteristics of natural water ( $3 \mathrm{~d}$ ed.): U.S. Geological Survey Water-Supply Paper 2254, 263 p.

Kendall, C., and McDonnell, J.J., 1998, Isotope tracers in catchment hydrology: New York, Elsevier, 839 p.

Klemt, W.B., Knowles, T.R., Elder, G.R., and Sieh, T.W., 1979, Ground-water resources and model applications for the Edwards (Balcones fault zone) aquifer in the San Antonio region: Texas Department of Water Resources Report 239, $88 \mathrm{p}$.

LBG-Guyton Associates, 2004, Evaluation of augmentation methodologies in support of in-situ refugia at Comal and San Marcos Springs, Texas: Report prepared for Edwards Aquifer Authority, $181 \mathrm{p}$.

Lindgren, R.J., Dutton, A.R., Hovorka, S.D., Worthington, S.R.H., and Painter, Scott, 2004, Conceptualization and simulation of the Edwards aquifer, San Antonio region, Texas: U.S. Geological Survey Scientific Investigations Report 2004-5277, 143 p.

Maclay, R.W., 1995, Geology and hydrology of the Edwards aquifer in the San Antonio area, Texas: U.S. Geological Survey Water-Resources Investigations Report 95-4186, $64 \mathrm{p}$. 
Maclay, R.W., and Land, L.F., 1988, Simulation of flow in the Edwards aquifer, San Antonio region, Texas, and refinement of storage and flow concepts: U.S. Geological Survey Water-Supply Paper 2336-A, 48 p.

Maclay, R.W., and Small, T.A., 1984, Carbonate geology and hydrology of the Edwards aquifer in the San Antonio area, Texas: U.S. Geological Survey Open-File Report 83-537, $72 \mathrm{p}$.

Milanovich, P.T., 1981, Water regime in deep karst—Case study of the Ombla Spring drainage area, in Yevjevich, V., ed., Karst Hydrology and Water Resources Publication: Littleton, Colo., p. 165-191.

Ogden, A.E., Spinelli, A.J., and Horton, J., 1985, Hydrologic and hydrochemical data for the Edwards aquifer in Hays and Comal Counties, October 1981 to September 1983: San Marcos, Tex., Southwest Texas State University, Edwards Aquifer Research and Data Center, Report R1-85, 102 p.

Padilla, A., Pulido-Bosch, A., and Mangin, A., 1994, Relative importance of baseflow and quickflow from hydrographs of karst springs: Ground Water, v. 32, p. 267-277.

Patton, C.J., and Truitt, E.P., 1992, Methods of analysis by the U.S. Geological Survey National Water Quality Laboratory-Determination of total phosphorus by a Kjeldahl digestion method and an automated colorimetric finish that includes dialysis: U.S. Geological Survey Open-File Report 92-146, 39 p.

Patton, C.J., and Truitt, E.P., 2000, Methods of analysis by the U.S. Geological Survey National Water Quality Laboratory-Determination of ammonium plus organic nitrogen by a Kjeldahl digestion method and an automated photometric finish that includes digest cleanup by gas diffusion: U.S. Geological Survey Open-File Report 00-170, 31 p.

Plummer, L.N., Bohkle, J.K., and Busenberg, Eurybiades, 2003, Approaches for ground-water dating, in Lindsey, B.D., Phillips, S.W., Donnelly, C.A., Speiran, G.K., Plummer, L.N., Bohkle, J.K., Focazio, M.J., Burton, W.C., and Busenberg, Eurybiades, Residence times and nitrate transport in ground water discharging to streams in the Chesapeake Bay Watershed: U.S. Geological Survey WaterResources Investigations Report 03-4035, p. 12-24.

Rose, P.R., 1972, Edwards Group, surface and subsurface, central Texas: Austin, University of Texas, Bureau of Economic Geology Report of Investigations 74, 198 p.

Schlosser P., Stute, M., Dorr, H., Sonntag, C., and Munnich, K.O., 1988, Tritium $/{ }^{3} \mathrm{He}$ dating of shallow groundwater: Earth and Planetary Science Letters, v. 89, p. 353-362.

Schultz, A.L., 1994, 1994 review and update of the position of the Edwards aquifer freshwater/saline-water interface from Uvalde to Kyle, Texas: Edwards Underground Water District Report 94-05, 31 p.
Shevenell, L., 1996, Analysis of well hydrographs in a karst aquifer-Estimates of specific yields and continuum transmissivities: Journal of Hydrology, v. 174, p. 331-355.

Small, T.A., 1986, Hydrogeologic sections of the Edwards aquifer and its confining units in the San Antonio area, Texas: U.S. Geological Survey Water-Resources Investigations Report 85-4259, $52 \mathrm{p}$.

Small, T.A., and Hanson, J.A., 1994, Geologic framework and hydrogeologic characteristics of the Edwards aquifer outcrop, Comal County, Texas: U.S. Geological Survey Water-Resources Investigations Report 94-4117, 10 p.

Stein,W.G., and Ozuna, G.B., 1994, Geologic framework and hydrogeologic characteristics of the Edwards aquifer outcrop, Bexar County, Texas: U.S. Geological Survey WaterResources Investigations Report 95-4030, 8 p.

U.S. Geological Survey, 2005, Quality assurance plan of the Reston Stable Isotope Laboratory-Reston Stable Isotope Laboratory Isotope Fractionation Project: accessed June 14, 2005, at http://isotopes.usgs.gov/Quality.htm

U.S. Geological Survey, 2006a, National Water Information System (NWISWeb) [for Texas] data available on the World Wide Web at http://waterdata.usgs.gov/tx/nwis/nwis

U.S. Geological Survey, 2006b, The Reston Chlorofluorocarbon Laboratory-Dissolved gas analysis, $\mathrm{SF}_{6}$ analysis, ${ }^{3} \mathrm{H} /{ }^{3} \mathrm{He}$ analysis: accessed January 17,2006 , at http://water. usgs.gov/lab

U.S. Geological Survey, 2006c, USGS National Water Quality Assessment Data Warehouse data available on the World Wide Web: accessed March 2006, at http://infotrek.er.usgs. gov/tranverse/f? $p=$ NAWQA:HOME:2081027407802063

Wilde, F.D., Radtke, D.B., Gibs, Jacob, and Iwatsubo, R.T., 1999, Collection of water samples: U.S. Geological Survey Techniques of Water-Resources Investigations, book 9, chap. A4, accessed February 15, 2003, at http://pubs.water. usgs.gov/twri9A4/.

Wilde, F.D., Radtke, D.B., Gibs, Jacob, and Iwatsubo, R.T., 2003, Cleaning of equipment for water samples (version 1.2): U.S. Geological Survey Techniques of WaterResources Investigations, book 9, chap. A3, accessed February 15, 2003, at http://pubs.water.usgs.gov/twri9A3/.

Wilde, F.D., Radtke, D.B., Gibs, Jacob, and Iwatsubo, R.T., 2004, Processing of water samples (version 2.1): U.S. Geological Survey Techniques of Water-Resources Investigations, book 9, chap. A5, accessed February 15, 2003, at http://pubs.water.usgs.gov/twri9A5/.

William F. Guyton and Associates, 1979, Geohydrology of Comal, San Marcos, and Hueco Springs: Texas Department of Water Resources Report 234, 85 p. 


\section{Appendix 1-Water-Level (2004-06) and Chemical Data (2003-06)}



Appendix 1.1. Daily mean depth to water at well DX-68-22-913, Comal County, Texas, 2004-06.

[In feet below land surface; ---, not collected or computed]

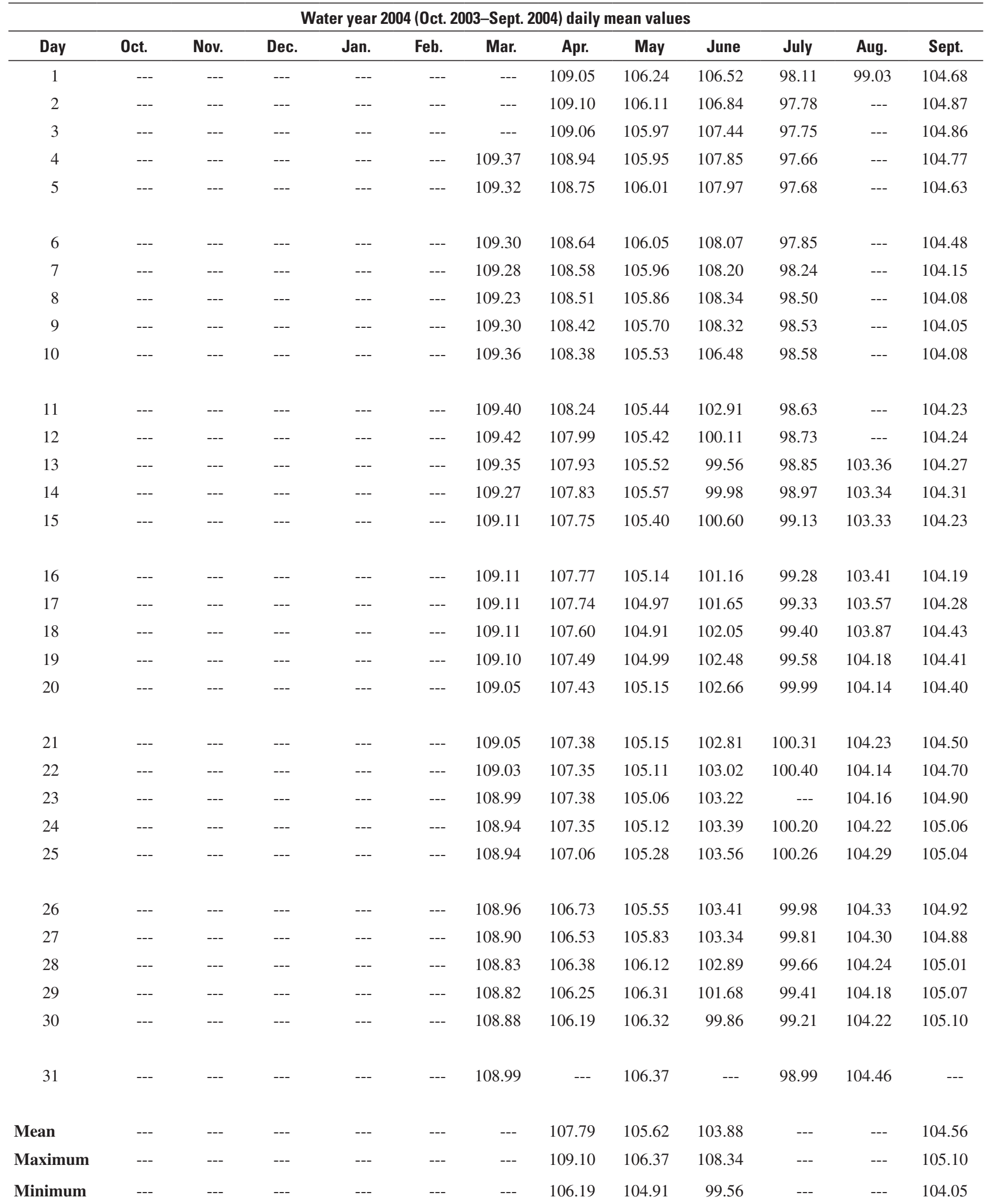


Appendix 1.1. Daily mean depth to water at well DX-68-22-913, Comal County, Texas, 2004-06-Continued.

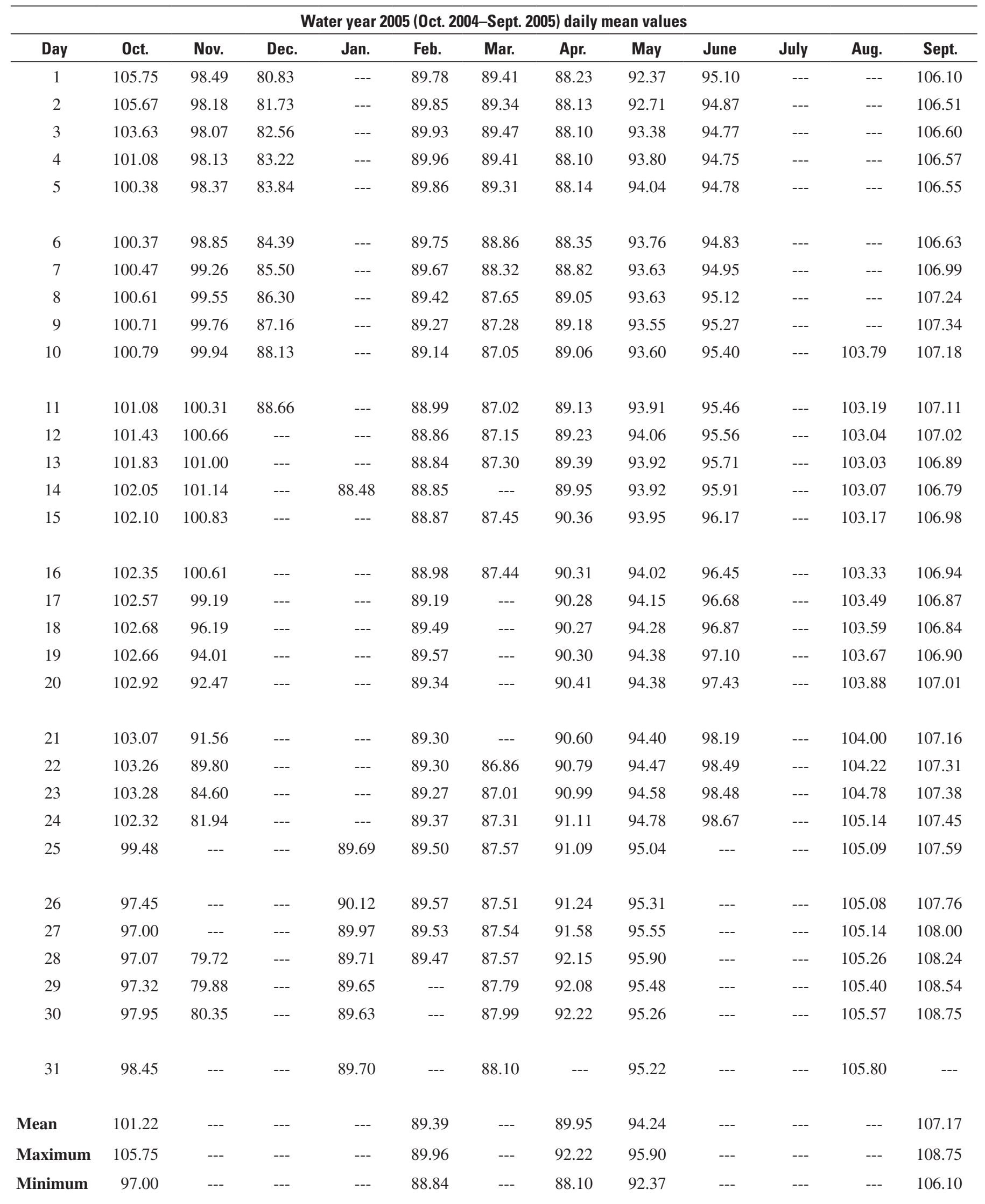


Appendix 1.1. Daily mean depth to water at well DX-68-22-913, Comal County, Texas, 2004-06-Continued.

\begin{tabular}{|c|c|c|c|c|c|c|c|c|c|c|c|c|}
\hline \multicolumn{13}{|c|}{ Water year 2006 (0ct. 2005-Sept. 2006) daily mean values } \\
\hline Day & 0ct. & Nov. & Dec. & Jan. & Feb. & Mar. & Apr. & May & June & July & Aug. & Sept. \\
\hline 1 & 108.88 & 107.83 & --- & --- & 110.85 & 112.18 & 114.66 & 117.79 & 120.01 & 123.79 & 125.97 & 128.54 \\
\hline 2 & 109.00 & 107.79 & --- & --- & 110.83 & 112.28 & 114.58 & 117.82 & 120.16 & 123.90 & 126.07 & 128.59 \\
\hline 3 & 109.11 & 107.85 & --- & --- & 110.87 & 112.37 & 114.57 & 117.80 & 120.27 & 124.01 & 126.17 & 128.64 \\
\hline 4 & 109.10 & 108.12 & --- & --- & 110.92 & 112.52 & 114.64 & 117.81 & 120.36 & 124.07 & 126.27 & 128.69 \\
\hline 5 & 108.39 & 108.14 & --- & 109.49 & 110.94 & 112.75 & 114.71 & 117.81 & 120.49 & 123.98 & 126.37 & 128.73 \\
\hline 6 & 107.78 & 108.11 & --- & 109.57 & 111.03 & 112.88 & 114.79 & 117.71 & 120.64 & 123.80 & 126.48 & 128.71 \\
\hline 7 & 107.87 & 108.09 & --- & 109.74 & 111.07 & 113.01 & 114.94 & 117.50 & 120.77 & 123.71 & 126.61 & 128.70 \\
\hline 8 & 107.86 & 108.12 & --- & 109.77 & 111.13 & 113.10 & 115.07 & 117.35 & 120.92 & 123.62 & 126.75 & 128.66 \\
\hline 9 & 107.79 & 108.19 & --- & --- & 111.25 & 113.20 & 115.15 & 117.28 & 121.08 & 123.55 & 126.85 & 128.59 \\
\hline 10 & 107.74 & 108.28 & --- & --- & 111.38 & 113.32 & 115.22 & 117.15 & 121.25 & 123.55 & 126.93 & 128.49 \\
\hline 11 & 107.76 & 108.33 & --- & 109.97 & 111.49 & 113.42 & 115.35 & 117.09 & 121.39 & 123.57 & 127.05 & 128.39 \\
\hline 12 & 107.74 & 108.34 & --- & 109.99 & 111.50 & 113.50 & 115.47 & 117.04 & 121.58 & 123.66 & 127.09 & 128.34 \\
\hline 13 & 107.64 & 108.35 & --- & 110.08 & 111.49 & 113.61 & 115.60 & 117.03 & 121.79 & 123.74 & 127.15 & 128.18 \\
\hline 14 & 107.53 & 108.34 & --- & 110.17 & 111.54 & 113.76 & 115.76 & 117.05 & 121.99 & 123.85 & 127.23 & 128.06 \\
\hline 15 & 107.42 & 108.37 & --- & 110.20 & 111.66 & 113.91 & 115.85 & 117.11 & 122.21 & 123.98 & 127.29 & 127.95 \\
\hline 16 & 107.34 & 108.45 & --- & 110.26 & 111.76 & 114.04 & 115.97 & 117.17 & 122.40 & 124.10 & 127.36 & 127.78 \\
\hline 17 & 107.32 & 108.51 & --- & 110.42 & 111.87 & 114.17 & 116.11 & 117.30 & 122.56 & 124.22 & 127.44 & 127.59 \\
\hline 18 & 107.30 & 108.73 & --- & --- & 111.94 & 114.28 & 116.33 & 117.41 & 122.62 & 124.38 & 127.53 & 127.39 \\
\hline 19 & 107.32 & 108.71 & --- & --- & 111.92 & 114.37 & 116.58 & 117.55 & 122.65 & 124.55 & 127.63 & 127.22 \\
\hline 20 & 107.39 & 108.67 & --- & --- & 111.89 & 114.43 & 116.81 & 117.72 & 122.54 & 124.74 & 127.72 & 127.04 \\
\hline 21 & 107.49 & 108.68 & --- & --- & 111.88 & 114.48 & 116.95 & 117.91 & 122.48 & 124.88 & 127.82 & 126.85 \\
\hline 22 & 107.54 & --- & --- & --- & 111.90 & 114.54 & 117.02 & 118.11 & 122.58 & 125.02 & 127.92 & 126.68 \\
\hline 23 & 107.57 & --- & --- & --- & --- & 114.63 & 117.07 & 118.33 & 122.64 & 125.13 & 128.03 & 126.53 \\
\hline 24 & 107.62 & 109.07 & --- & --- & 112.08 & 114.68 & 117.13 & 118.54 & 122.74 & 125.27 & 128.14 & 126.38 \\
\hline 25 & 107.62 & 109.08 & --- & 110.68 & 112.09 & 114.70 & 117.23 & 118.79 & 122.83 & 125.35 & 128.21 & 126.28 \\
\hline 26 & 107.66 & --- & --- & 110.72 & 112.10 & 114.68 & 117.33 & 119.04 & 122.96 & 125.44 & 128.28 & 126.20 \\
\hline 27 & 107.74 & --- & --- & 110.79 & 112.07 & 114.67 & 117.41 & 119.25 & 123.13 & 125.52 & 128.35 & 126.10 \\
\hline 28 & 107.83 & 108.99 & --- & 110.79 & 112.10 & 114.67 & 117.49 & 119.45 & 123.31 & 125.61 & 128.41 & 126.02 \\
\hline 29 & 107.89 & 108.96 & --- & 110.74 & --- & 114.64 & 117.57 & 119.61 & 123.47 & 125.70 & 128.46 & 125.94 \\
\hline 30 & 107.88 & --- & --- & 110.79 & --- & 114.64 & 117.68 & 119.74 & 123.64 & 125.78 & 128.48 & 125.88 \\
\hline 31 & 107.85 & --- & --- & 110.84 & --- & 114.70 & --- & 119.86 & --- & 125.87 & 128.50 & --- \\
\hline Mean & 107.84 & --- & --- & --- & --- & 113.81 & 116.03 & 117.97 & 121.92 & 124.46 & 127.37 & 127.57 \\
\hline Maximum & 109.11 & --- & --- & --- & --- & 114.70 & 117.68 & 119.86 & 123.64 & 125.87 & 128.50 & 128.73 \\
\hline Minimum & 107.30 & --- & --- & --- & --- & 112.18 & 114.57 & 117.03 & 120.01 & 123.55 & 125.97 & 125.88 \\
\hline
\end{tabular}


Appendix 1.2. Daily mean depth to water at well DX-68-23-502, Comal County, Texas, 2004-06.

[In feet below land surface; ---, not collected or computed]

\section{Water year 2004 (0ct. 2003-Sept. 2004) daily mean values}

\begin{tabular}{|c|c|c|c|c|c|c|c|c|c|c|c|c|}
\hline Day & Oct. & Nov. & Dec. & Jan. & Feb. & Mar. & Apr. & May & June & July & Aug. & Sept \\
\hline 1 & --- & --- & --- & --- & --- & --- & 32.40 & 30.44 & 31.13 & 27.62 & 27.93 & 29.71 \\
\hline 2 & --- & --- & --- & --- & --- & --- & 32.36 & 30.25 & 31.50 & 27.36 & 28.13 & 29.75 \\
\hline 4 & --- & --- & --- & --- & --- & --- & 31.99 & 30.34 & 31.88 & 26.79 & 28.51 & 29.69 \\
\hline 5 & --- & --- & --- & --- & --- & --- & 31.97 & 30.32 & 31.77 & 26.70 & 28.64 & 29.43 \\
\hline 6 & --- & --- & --- & --- & --- & --- & 31.99 & 30.32 & 31.76 & 26.88 & 28.75 & 29.37 \\
\hline 7 & --- & --- & --- & --- & --- & --- & 31.92 & 30.30 & 32.00 & 26.96 & 28.57 & 29.43 \\
\hline 8 & --- & --- & --- & --- & --- & --- & 31.88 & 30.08 & 32.09 & 26.96 & 28.48 & 29.49 \\
\hline 9 & --- & --- & --- & --- & --- & --- & 31.80 & 29.94 & 31.63 & 26.99 & 28.58 & 29.52 \\
\hline 10 & --- & --- & --- & --- & --- & --- & 31.60 & 30.01 & 30.35 & 26.82 & 28.74 & 29.55 \\
\hline 12 & --- & --- & --- & --- & --- & --- & 31.36 & 30.03 & 29.66 & 26.76 & 28.94 & 29.48 \\
\hline 13 & --- & --- & --- & --- & --- & --- & 31.43 & 29.97 & 29.31 & 26.91 & 29.04 & 29.60 \\
\hline 14 & --- & --- & --- & --- & --- & --- & 31.41 & 29.89 & 29.31 & 26.97 & 28.95 & 29.67 \\
\hline 15 & --- & --- & --- & --- & --- & --- & 31.36 & 29.67 & 29.35 & 27.09 & 28.89 & 29.58 \\
\hline 16 & --- & --- & --- & --- & --- & --- & 31.36 & 29.47 & 29.33 & 27.19 & 29.07 & 29.55 \\
\hline 17 & --- & --- & --- & --- & --- & --- & 31.19 & 29.54 & 29.34 & 27.14 & 29.29 & 29.59 \\
\hline 18 & --- & --- & --- & --- & --- & 32.29 & 31.04 & 29.68 & 29.37 & 27.07 & 29.44 & 29.61 \\
\hline 19 & --- & --- & --- & --- & --- & 32.29 & 31.14 & 29.70 & 29.27 & 27.26 & 29.48 & 29.53 \\
\hline 25 & --- & --- & --- & --- & --- & 32.27 & 30.96 & 30.18 & 29.46 & 27.67 & 29.57 & 29.76 \\
\hline 26 & --- & --- & --- & --- & --- & 32.28 & 30.84 & 30.34 & 29.25 & 27.61 & 29.60 & 29.69 \\
\hline 27 & --- & --- & --- & --- & --- & 32.12 & 30.85 & 30.50 & 29.03 & 27.80 & 29.65 & 29.79 \\
\hline 28 & --- & --- & --- & --- & --- & 32.00 & 30.78 & 30.67 & 28.93 & 27.92 & 29.58 & 29.90 \\
\hline 29 & --- & --- & --- & --- & --- & 32.16 & 30.72 & 30.68 & 28.73 & 27.99 & 29.35 & 30.00 \\
\hline 30 & --- & --- & --- & --- & --- & 32.29 & 30.62 & 30.68 & 28.10 & 28.04 & 29.50 & 30.02 \\
\hline 31 & --- & --- & --- & --- & --- & 32.37 & --- & 30.84 & --- & 27.97 & 29.66 & --- \\
\hline Mean & --- & --- & --- & --- & --- & --- & 31.42 & 30.11 & 30.05 & 27.33 & 29.07 & 29.66 \\
\hline Maximum & --- & --- & --- & --- & --- & --- & 32.40 & 30.84 & 32.09 & 28.04 & 29.66 & 30.02 \\
\hline Minimum & --- & --- & --- & --- & --- & --- & 30.62 & 29.47 & 28.10 & 26.69 & 27.93 & 29.37 \\
\hline
\end{tabular}


Appendix 1.2. Daily mean depth to water at well DX-68-23-502, Comal County, Texas, 2004-06-Continued.

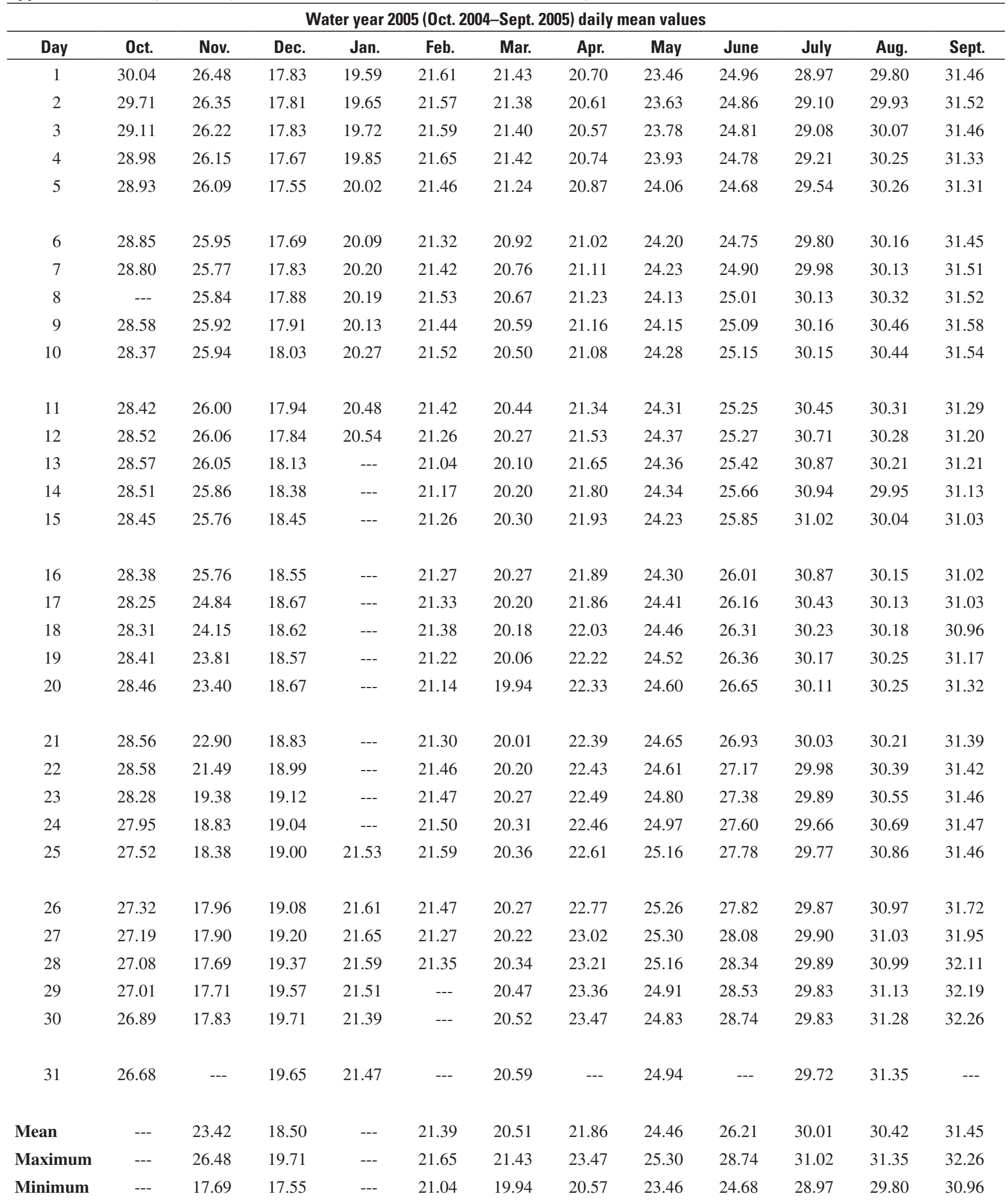


38 Geologic, Hydrologic, and Geochemical Identification of Flow Paths in the Edwards Aquifer ... Texas

Appendix 1.2. Daily mean depth to water at well DX-68-23-502, Comal County, Texas, 2004-06-Continued.

\begin{tabular}{|c|c|c|c|c|c|c|c|c|c|c|c|c|}
\hline \multicolumn{13}{|c|}{ Water year 2006 (Oct. 2005-Sept. 2006) daily mean values } \\
\hline Day & Oct. & Nov. & Dec. & Jan. & Feb. & Mar. & Apr. & May & June & July & Aug. & Sept. \\
\hline 1 & 32.28 & 31.04 & 32.73 & 32.62 & 33.55 & 34.87 & 36.45 & 38.99 & 41.46 & 45.04 & 46.20 & 47.72 \\
\hline 3 & 32.38 & 31.20 & 32.78 & 32.88 & 33.71 & 35.11 & 36.58 & 39.19 & 41.41 & 44.54 & 46.47 & 47.31 \\
\hline 4 & --- & 31.28 & 32.78 & 33.04 & 33.80 & 35.21 & 36.69 & 39.23 & 41.39 & 44.41 & 46.66 & 47.30 \\
\hline 6 & 31.33 & 31.20 & 32.79 & 33.25 & 33.86 & 35.49 & 36.92 & 38.67 & 41.97 & 43.51 & 46.34 & 47.03 \\
\hline 7 & 30.42 & 31.42 & 32.78 & 33.23 & 33.96 & 35.62 & 37.02 & 38.20 & 42.18 & 43.38 & 46.32 & 46.82 \\
\hline 8 & 30.30 & 31.56 & 32.71 & 33.12 & 34.03 & 35.73 & 37.11 & 38.03 & 42.40 & 43.19 & 46.45 & 46.72 \\
\hline 9 & 30.28 & 31.64 & 32.80 & 33.25 & 34.09 & 35.78 & 37.08 & 37.97 & --- & 43.11 & 46.53 & 46.39 \\
\hline 12 & 30.23 & 31.77 & 32.67 & 33.35 & 34.06 & --- & 37.70 & 38.08 & --- & 43.94 & 46.82 & 45.85 \\
\hline 13 & 30.17 & 31.73 & 32.71 & 33.47 & 34.20 & --- & 37.85 & 38.18 & --- & 44.23 & 46.61 & 45.51 \\
\hline 14 & 30.16 & 31.91 & 32.73 & 33.41 & 34.36 & --- & 38.01 & 38.19 & --- & 44.48 & 46.84 & 45.32 \\
\hline 15 & 30.11 & 32.02 & 32.78 & 33.44 & 34.46 & 36.80 & 38.19 & 38.35 & --- & 44.47 & 47.10 & 45.19 \\
\hline 16 & 30.05 & 32.11 & 32.72 & 33.49 & 34.49 & 36.79 & 38.21 & 38.59 & --- & 44.46 & 47.28 & 44.97 \\
\hline 17 & 30.21 & 32.17 & 32.65 & 33.54 & 34.61 & 36.88 & 38.43 & 38.90 & --- & 44.78 & 47.41 & 44.72 \\
\hline 18 & 30.28 & 32.20 & 32.53 & 33.54 & 34.66 & 36.89 & 38.71 & 39.19 & --- & 45.24 & 47.55 & 44.54 \\
\hline 24 & 30.71 & 32.43 & 32.44 & 33.60 & 34.73 & 36.80 & 38.92 & 40.76 & 44.00 & --- & 47.64 & 43.73 \\
\hline 25 & 30.76 & 32.37 & 32.39 & 33.66 & 34.71 & 36.71 & 39.09 & 41.04 & 43.97 & 45.64 & 47.72 & 43.73 \\
\hline 26 & 30.84 & 32.40 & 32.43 & 33.61 & 34.60 & 36.55 & 39.17 & 41.29 & 44.19 & 45.71 & 47.62 & 43.84 \\
\hline 27 & 30.90 & 32.34 & 32.56 & 33.65 & 34.68 & 36.59 & 39.26 & 41.53 & 44.53 & 45.84 & 47.32 & 43.84 \\
\hline 28 & 31.00 & 32.50 & 32.70 & 33.60 & 34.81 & 36.57 & 39.23 & 41.46 & 44.76 & 45.95 & 47.39 & 43.85 \\
\hline 29 & 31.02 & 32.64 & 32.78 & 33.45 & --- & 36.48 & 39.13 & 41.25 & 44.99 & 45.92 & 47.63 & 43.89 \\
\hline 30 & 30.86 & 32.69 & 32.71 & 33.43 & --- & 36.45 & 38.91 & 41.23 & 45.22 & 45.75 & 47.52 & 43.85 \\
\hline 31 & 30.98 & --- & 32.63 & 33.53 & --- & 36.48 & --- & 41.39 & --- & 45.94 & 47.57 & --- \\
\hline Mean & --- & 31.93 & 32.67 & --- & 34.29 & --- & 38.05 & --- & --- & --- & 47.06 & 45.34 \\
\hline Maximum & --- & 32.69 & 32.87 & --- & 34.81 & --- & 39.26 & --- & --- & --- & 47.72 & 47.72 \\
\hline Minimum & --- & 31.04 & 32.39 & --- & 33.55 & --- & 36.38 & --- & --- & --- & 46.20 & 43.73 \\
\hline
\end{tabular}


Appendix 1.3. Chemical and isotope data in ground-water samples from wells and springs (by flow path) collected for this study, northeastern Bexar and southern Comal Counties, Texas, 2003-06.

[USGS, U.S. Geological Survey; ${ }^{\circ} \mathrm{C}$, degrees Celsius; $\mu \mathrm{S} / \mathrm{cm}$, microsiemens per centimeter at $25{ }^{\circ} \mathrm{C} ; \mathrm{mg} / \mathrm{L}$, milligrams per liter; W, well; --, not analyzed for or not detected; dup, duplicate; Sp, spring; R, Rainfall; $\mathrm{CaCO}_{3}$, calcium carbonate; <, less than; E, estimated; $\mu \mathrm{g} / \mathrm{L}$, micrograms per liter; pptv, parts per trillion by volume; $\delta \mathrm{D}$, delta deuterium; per mil, parts per thousand; $\delta^{18} \mathrm{O}$, delta oxygen- $18 ;{ }^{3} \mathrm{H}$, tritium; TU, tritium units; ${ }^{3} \mathrm{He}$, helium-3; M, presence of material verified but not quantified]

\begin{tabular}{|c|c|c|c|c|c|c|c|c|c|}
\hline $\begin{array}{l}\text { Site } \\
\text { type }\end{array}$ & $\begin{array}{c}\text { State well } \\
\text { number } \\
\text { (USGS name) }\end{array}$ & Date & Time & $\begin{array}{c}\text { Temperature, } \\
\text { water } \\
\left({ }^{\circ} \mathrm{C}\right)\end{array}$ & $\begin{array}{c}\text { pH } \\
\text { (standard } \\
\text { units) }\end{array}$ & $\begin{array}{c}\text { Specific } \\
\text { conduct- } \\
\text { ance } \\
(\mu \mathrm{S} / \mathrm{cm})\end{array}$ & $\begin{array}{c}\text { Dissolved } \\
\text { oxygen } \\
\text { (mg/L) }\end{array}$ & $\begin{array}{c}\text { Calcium } \\
\text { (mg/L) }\end{array}$ & $\begin{array}{c}\text { Magne- } \\
\text { sium } \\
\text { (mg/L) }\end{array}$ \\
\hline
\end{tabular}

\begin{tabular}{|c|c|c|c|c|c|c|c|c|c|}
\hline \multicolumn{10}{|c|}{ Southern Comal flow path } \\
\hline \multirow[t]{2}{*}{ W } & AY-68-29-610 & $7 / 28 / 2003$ & 1200 & 22.5 & 7 & 608 & -- & 100 & 13.5 \\
\hline & & $7 / 28 / 2003$ dup & 1201 & -- & -- & -- & -- & -- & -- \\
\hline \multirow[t]{2}{*}{ W } & AY-68-29-913 & $7 / 28 / 2003$ & 1100 & 24.5 & 7.1 & 515 & -- & 73.2 & 15.9 \\
\hline & & $7 / 28 / 2003$ dup & 1101 & -- & -- & -- & -- & -- & -- \\
\hline \multirow[t]{2}{*}{ W } & AY-68-29-914 & $7 / 28 / 2003$ & 1000 & 25 & 7.2 & 493 & -- & 68.2 & 16.1 \\
\hline & & $7 / 28 / 2003$ dup & 1001 & -- & -- & -- & -- & -- & -- \\
\hline \multirow[t]{3}{*}{ W } & DX-68-23-304 & $6 / 18 / 2003$ & 1400 & 24 & 7.2 & 558 & 2.5 & 79.9 & 17 \\
\hline & (NBU-LCRA) & $6 / 18 / 2003$ dup & 1401 & -- & -- & -- & -- & -- & -- \\
\hline & & $3 / 1 / 2006$ & 1330 & 24.5 & 7.1 & 533 & 4.5 & 84.6 & 16.5 \\
\hline \multirow[t]{3}{*}{$\mathrm{Sp}$} & DX-68-23-324 & $7 / 22 / 2003$ & 1230 & 23.9 & 7.1 & 547 & -- & 84.7 & 17 \\
\hline & (Comal 7) & $7 / 22 / 2003$ dup & 1231 & -- & -- & -- & -- & -- & -- \\
\hline & & $3 / 8 / 2006$ & 1430 & 23.5 & 7.1 & 561 & 5.4 & 77.7 & 16.4 \\
\hline \multirow[t]{3}{*}{$\mathrm{Sp}$} & DX-68-23-325 & $8 / 7 / 2003$ & 1030 & -- & -- & -- & -- & 79.4 & 17.8 \\
\hline & (Comal-Spring Island) & 8/7/2003 dup & 1100 & -- & -- & -- & -- & 98.7 & 18.5 \\
\hline & & $3 / 8 / 2006$ & 1400 & 23.5 & 7.1 & 562 & 5.1 & 82.5 & 15.6 \\
\hline \multirow[t]{3}{*}{$\mathrm{Sp}$} & DX-68-23-326 & $7 / 22 / 2003$ & 1330 & 24 & 7.1 & 548 & -- & 86.8 & 17.6 \\
\hline & (Comal 5) & $7 / 22 / 2003$ dup & 1331 & -- & -- & -- & -- & -- & -- \\
\hline & & $3 / 8 / 2006$ & 1330 & 23.5 & 7.1 & 565 & 4.9 & 77.5 & 16.1 \\
\hline \multirow[t]{2}{*}{ W } & DX-68-23-602 & $7 / 24 / 2003$ & 1100 & 23 & 7 & 544 & -- & 83.2 & 13.5 \\
\hline & & $7 / 24 / 2003$ dup & 1101 & -- & -- & -- & -- & -- & -- \\
\hline \multicolumn{10}{|c|}{ Central Comal flow path } \\
\hline \multirow[t]{2}{*}{ W } & AY-68-29-811 & $7 / 28 / 2003$ & 0900 & 23.5 & 7 & 555 & -- & 82.9 & 17.4 \\
\hline & & 7/28/2003 dup & 0901 & -- & -- & -- & -- & -- & -- \\
\hline \multirow[t]{2}{*}{ W } & AY $-68-30-520$ & $7 / 17 / 2003$ & 1100 & 26 & 7 & 527 & 5.5 & 74.9 & 16.7 \\
\hline & & 7/17/2003 dup & 1101 & -- & -- & -- & -- & -- & -- \\
\hline \multirow[t]{3}{*}{$\mathrm{Sp}$} & DX-68-15-901 & $3 / 5 / 2003$ & 1400 & 20 & 6.7 & 613 & 6.7 & 109 & 9.81 \\
\hline & (Hueco A) & $3 / 5 / 2003$ dup & 1401 & -- & -- & -- & -- & -- & -- \\
\hline & & $3 / 16 / 2006$ & 1300 & 20.5 & 7.1 & 594 & 5.5 & 86 & 17.9 \\
\hline \multirow[t]{2}{*}{ Sp } & DX-68-15-913 & $3 / 6 / 2003$ & 1100 & 20 & 6.6 & 615 & 6.5 & 107 & 9.71 \\
\hline & (Hueco B) & 3/6/2003 dup & 1101 & -- & -- & -- & -- & -- & -- \\
\hline
\end{tabular}


Appendix 1.3. Chemical and isotope data in ground-water samples from wells and springs (by flow path) collected for this study, northeastern Bexar and southern Comal Counties, Texas, 2003-06-Continued.

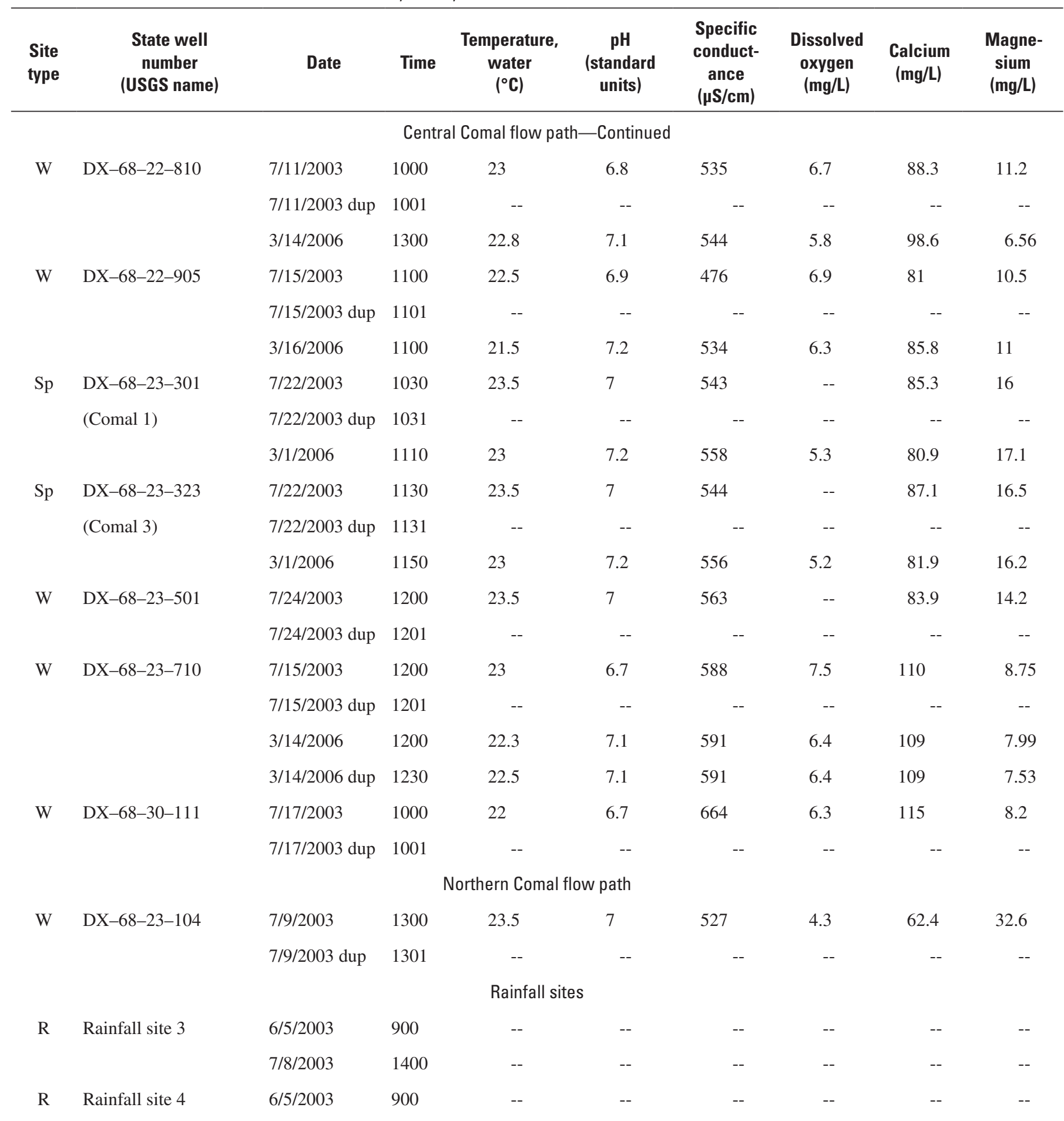


Appendix 1.3. Chemical and isotope data in ground-water samples from wells and springs (by flow path) collected for this study, northeastern Bexar and southern Comal Counties, Texas, 2003-06-Continued.

\begin{tabular}{|c|c|c|c|c|c|c|c|c|c|c|}
\hline $\begin{array}{c}\text { State well } \\
\text { number } \\
\text { (USGS name) }\end{array}$ & $\begin{array}{c}\text { Potas- } \\
\text { sium } \\
(\mathrm{mg} / \mathrm{L})\end{array}$ & $\begin{array}{c}\text { Sodium } \\
\text { adsorp- } \\
\text { tion } \\
\text { ratio }\end{array}$ & $\begin{array}{c}\text { Sodium } \\
\text { (mg/L) }\end{array}$ & $\begin{array}{l}\text { Sodium } \\
\text { (per- } \\
\text { cent) }\end{array}$ & $\begin{array}{c}\text { Alkalinity } \\
\text { (mg/L as } \\
\mathrm{CaCO}_{3} \text { ) }\end{array}$ & $\begin{array}{l}\text { Bicar- } \\
\text { bonate } \\
(\mathrm{mg} / \mathrm{L})\end{array}$ & $\begin{array}{c}\text { Carbonate } \\
\text { (mg/L) }\end{array}$ & $\begin{array}{c}\text { Chloride } \\
\text { (mg/L) }\end{array}$ & $\begin{array}{c}\text { Fluoride } \\
\text { (mg/L) }\end{array}$ & $\begin{array}{l}\text { Silica } \\
\text { (mg/L) }\end{array}$ \\
\hline \multicolumn{11}{|c|}{ Southern Comal flow path } \\
\hline AY-68-29-610 & 2.26 & 0.3 & 10.3 & 7 & 257 & 313 & 0 & 15.7 & 0.19 & 12.3 \\
\hline \multirow[t]{2}{*}{ AY-68-29-913 } & 1.24 & .3 & 10.6 & 8 & 210 & 256 & 0 & 17.7 & .2 & 12.8 \\
\hline & -- & -- & -- & -- & -- & -- & -- & -- & -- & -- \\
\hline AY-68-29-914 & 1.16 & .3 & 10.1 & 8 & 194 & 237 & 0 & 19.8 & .2 & 12.6 \\
\hline \multirow[t]{2}{*}{ (NBU-LCRA) } & -- & -- & -- & -- & -- & -- & -- & -- & -- & -- \\
\hline & 1.41 & .3 & 9.61 & 7 & 244 & 296 & $<1$ & 15.4 & .26 & 12.7 \\
\hline DX-68-23-324 & 1.28 & .3 & 10.6 & 8 & 220 & 268 & 0 & 17.6 & .23 & 12.9 \\
\hline \multirow[t]{2}{*}{ (Comal 7) } & -- & -- & -- & -- & -- & -- & -- & -- & -- & -- \\
\hline & 1.57 & .3 & 10.4 & 8 & 242 & 295 & $<1$ & 16.9 & .27 & 12.5 \\
\hline DX-68-23-325 & 1.47 & .3 & 9.78 & 7 & 228 & 278 & 0 & 15.6 & .2 & 12.7 \\
\hline (Comal-Spring Island) & 1.58 & .2 & 9.48 & 6 & 226 & 276 & 0 & 16.9 & .21 & 12.8 \\
\hline \multirow[t]{2}{*}{ DX-68-23-602 } & 1.18 & .2 & 8.27 & 6 & 236 & 288 & 0 & 13.7 & .22 & 12.7 \\
\hline & -- & -- & -- & -- & -- & -- & -- & -- & -- & -- \\
\hline \multicolumn{11}{|c|}{ Central Comal flow path } \\
\hline \multirow[t]{2}{*}{ AY-68-29-811 } & 1.29 & .3 & 10.6 & 8 & 225 & 275 & 0 & 16.2 & .21 & 12.7 \\
\hline & -- & -- & -- & -- & -- & -- & -- & -- & -- & -- \\
\hline \multirow[t]{2}{*}{ AY $-68-30-520$} & 1.41 & .3 & 10.8 & 8 & 196 & 239 & 0 & 20.9 & .22 & 12.8 \\
\hline & -- & -- & -- & -- & -- & -- & -- & -- & -- & -- \\
\hline DX-68-15-901 & 1.07 & .2 & 7.98 & 5 & 268 & 327 & 0 & 12.4 & .15 & 9.9 \\
\hline \multirow[t]{2}{*}{ (Hueco A) } & -- & -- & -- & -- & -- & -- & -- & -- & -- & -- \\
\hline & 1.41 & .2 & 9.29 & 7 & 272 & 331 & $<1$ & 14.1 & .3 & 11 \\
\hline DX-68-15-913 & 1.07 & .2 & 7.92 & 5 & 266 & 324 & 0 & 13.3 & .15 & 9.9 \\
\hline (Hueco B) & -- & -- & -- & -- & -- & -- & -- & -- & -- & -- \\
\hline
\end{tabular}


Appendix 1.3. Chemical and isotope data in ground-water samples from wells and springs (by flow path) collected for this study, northeastern Bexar and southern Comal Counties, Texas, 2003-06_Continued.

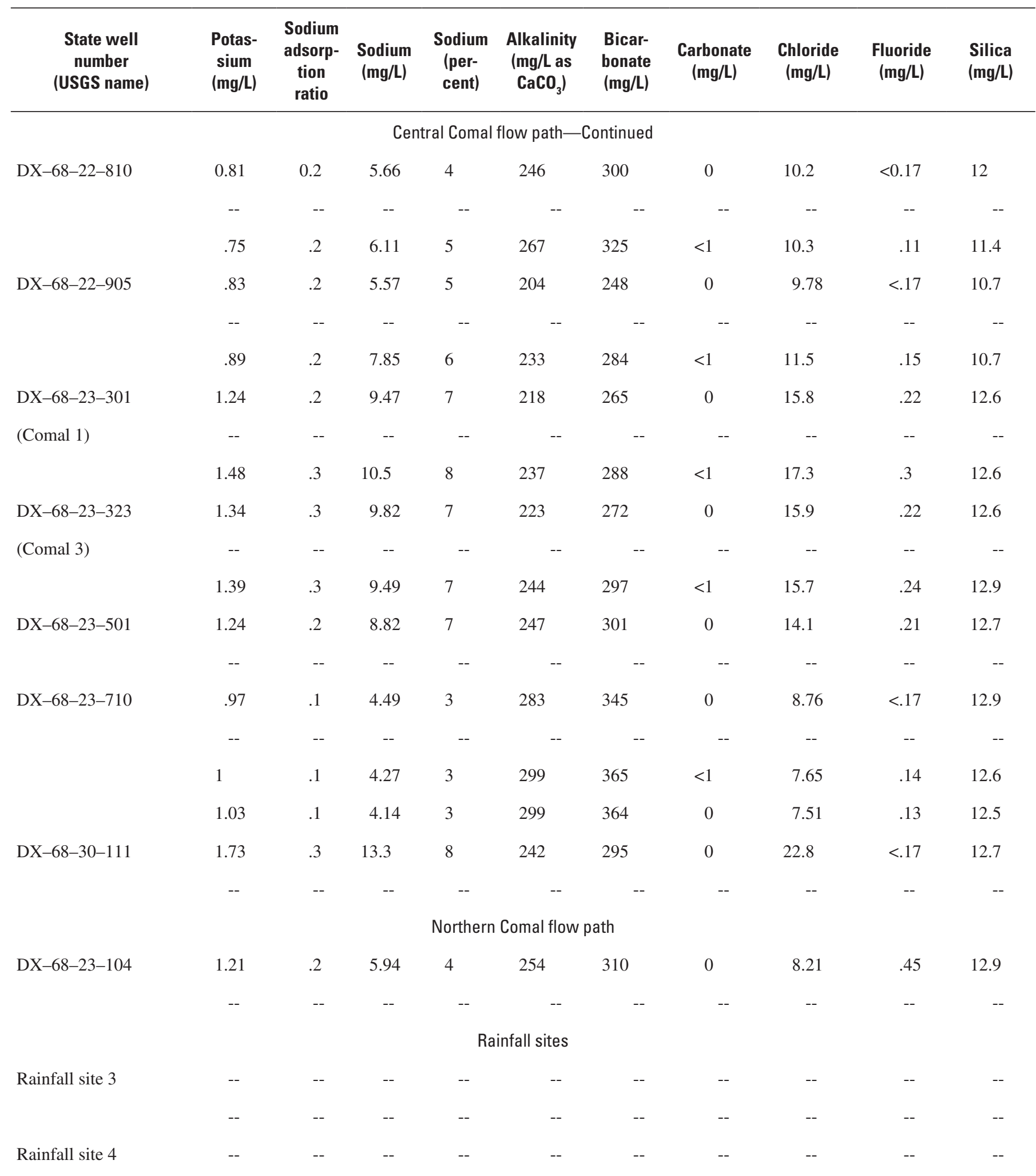


Appendix 1.3. Chemical and isotope data in ground-water samples from wells and springs (by flow path) collected for this study, northeastern Bexar and southern Comal Counties, Texas, 2003-06-Continued.

\begin{tabular}{|c|c|c|c|c|c|c|c|c|c|}
\hline $\begin{array}{c}\text { State well } \\
\text { number } \\
\text { (USGS name) }\end{array}$ & $\begin{array}{l}\text { Sulfate } \\
\text { (mg/L) }\end{array}$ & $\begin{array}{c}\text { Residue } \\
\text { (sum of } \\
\text { constit- } \\
\text { uents) } \\
\text { (mg/L) }\end{array}$ & $\begin{array}{l}\text { Dissolved } \\
\text { ammonia } \\
\text { plus organic } \\
\text { nitrogen } \\
\text { (mg/L) }\end{array}$ & $\begin{array}{c}\text { Dissolved } \\
\text { ammonia } \\
\text { nitrogen } \\
\text { (mg/L) }\end{array}$ & $\begin{array}{l}\text { Dissolved } \\
\text { nitrite plus } \\
\text { nitrate } \\
\text { nitrogen } \\
\text { (mg/L) }\end{array}$ & $\begin{array}{l}\text { Dissolved } \\
\text { nitrite } \\
\text { nitrogen } \\
\text { (mg/L) }\end{array}$ & $\begin{array}{l}\text { Dissolved } \\
\text { orthophos- } \\
\text { phate } \\
\text { phosphorus } \\
\text { (mg/L) }\end{array}$ & $\begin{array}{c}\text { Dissolved } \\
\text { phosphorus } \\
\text { (mg/L) }\end{array}$ & $\begin{array}{c}\text { Alumi- } \\
\text { num } \\
(\mu \mathrm{g} / \mathrm{L})\end{array}$ \\
\hline \multicolumn{10}{|c|}{ Southern Comal flow path } \\
\hline AY-68-29-610 & -- & -- & -- & -- & -- & -- & -- & -- & -- \\
\hline \multirow[t]{2}{*}{ AY-68-29-913 } & 21.2 & 287 & $<.10$ & $<.04$ & 1.84 & $<.008$ & $<.02$ & $<.04$ & $<1.6$ \\
\hline & -- & -- & -- & -- & -- & -- & -- & -- & -- \\
\hline AY-68-29-914 & 17.1 & 270 & $<.10$ & $<.04$ & 1.91 & $<.008$ & $<.02$ & $<.04$ & E.9 \\
\hline \multirow[t]{2}{*}{ (NBU-LCRA) } & -- & -- & -- & -- & -- & -- & -- & -- & -- \\
\hline & 22.9 & 309 & -- & -- & -- & -- & -- & -- & 2.1 \\
\hline DX-68-23-324 & 23.5 & 308 & $<.10$ & $<.04$ & 1.91 & $<.008$ & $<.02$ & $<.04$ & $<1.6$ \\
\hline \multirow[t]{2}{*}{ (Comal 7) } & -- & -- & -- & -- & -- & -- & -- & -- & -- \\
\hline & 25.3 & 306 & -- & -- & -- & -- & -- & -- & $<1.6$ \\
\hline DX-68-23-325 & 22 & 304 & $<.10$ & $<.04$ & 1.78 & $<.008$ & $<.02$ & $<.04$ & E1.1 \\
\hline (Comal-Spring Island) & 21.9 & 324 & $<.10$ & $<.04$ & 1.78 & $<.008$ & E.01 & $<.04$ & E. 8 \\
\hline \multirow[t]{2}{*}{ DX-68-23-602 } & 17.1 & 300 & $<.10$ & $<.04$ & 1.89 & $<.008$ & E.01 & $<.04$ & 2.7 \\
\hline & -- & -- & -- & -- & -- & -- & -- & -- & -- \\
\hline \multicolumn{10}{|c|}{ Central Comal flow path } \\
\hline \multirow[t]{2}{*}{ AY-68-29-811 } & 29.2 & 314 & $<.10$ & $<.04$ & 1.76 & $<.008$ & $<.02$ & $<.04$ & $<1.6$ \\
\hline & -- & -- & -- & -- & -- & -- & -- & -- & -- \\
\hline \multirow[t]{2}{*}{ AY-68-30-520 } & 22.9 & 287 & $<.10$ & $<.04$ & 1.89 & $<.008$ & $<.02$ & $<.04$ & $<1.6$ \\
\hline & -- & -- & -- & -- & -- & -- & -- & -- & -- \\
\hline DX-68-15-901 & 17.6 & 333 & E.06 & $<.04$ & .92 & $<.008$ & $<.02$ & $<.04$ & $<1.6$ \\
\hline \multirow[t]{2}{*}{ (Hueco A) } & -- & -- & -- & -- & -- & -- & -- & -- & -- \\
\hline & 29.2 & 332 & -- & -- & -- & -- & -- & -- & $<1.6$ \\
\hline DX-68-15-913 & 17.9 & 330 & E.06 & $<.04$ & .91 & $<.008$ & $<.02$ & $<.04$ & $<1.6$ \\
\hline (Hueco B) & -- & -- & -- & -- & -- & -- & -- & -- & -- \\
\hline
\end{tabular}


Appendix 1.3. Chemical and isotope data in ground-water samples from wells and springs (by flow path) collected for this study, northeastern Bexar and southern Comal Counties, Texas, 2003-06-Continued.

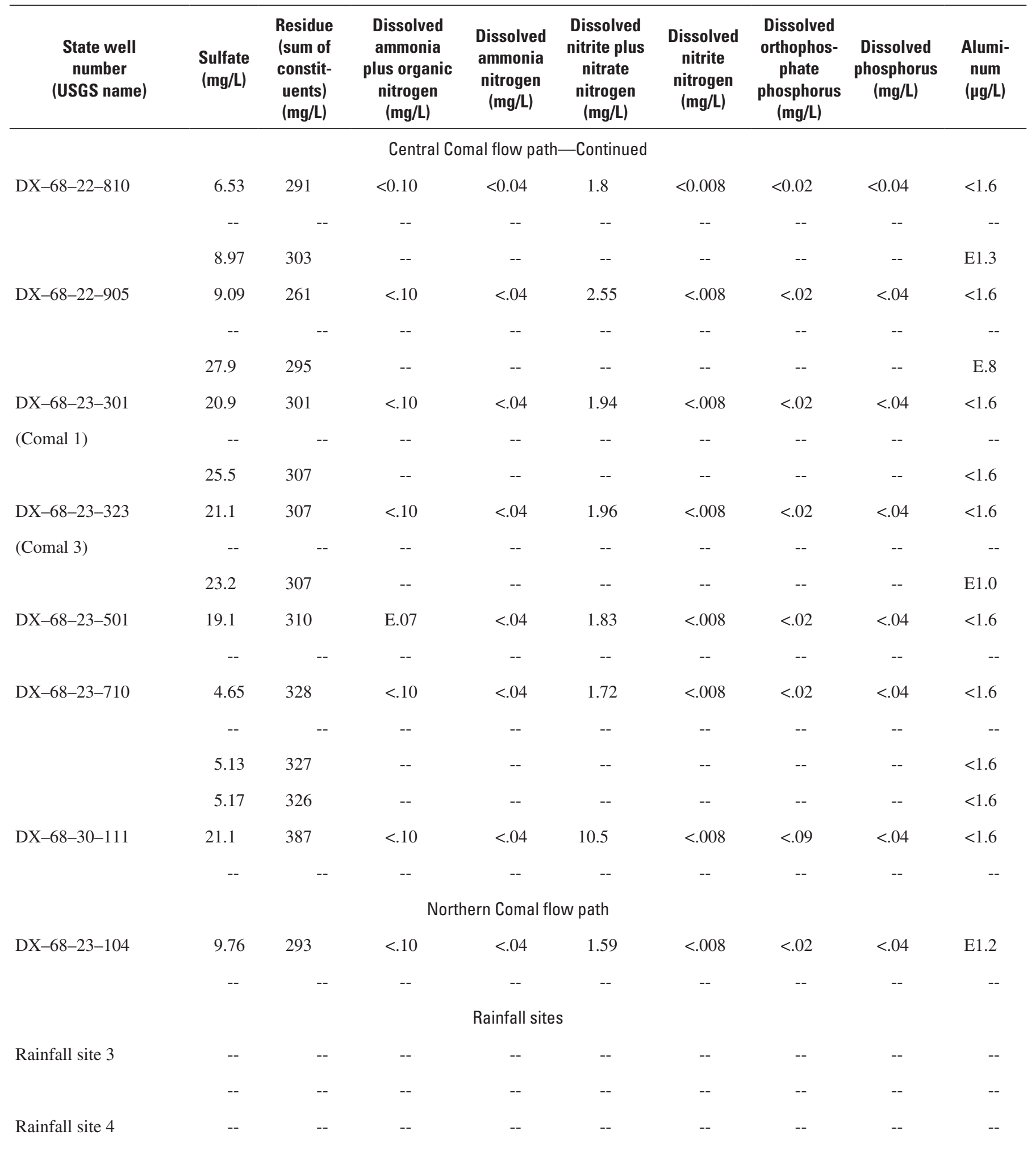


Appendix 1.3. Chemical and isotope data in ground-water samples from wells and springs (by flow path) collected for this study, northeastern Bexar and southern Comal Counties, Texas, 2003-06-Continued.

\begin{tabular}{|c|c|c|c|c|c|c|c|c|c|c|}
\hline $\begin{array}{c}\text { State well } \\
\text { number } \\
\text { (USGS name) }\end{array}$ & $\begin{array}{l}\text { Anti- } \\
\text { mony } \\
(\mu \mathrm{g} / \mathrm{L})\end{array}$ & $\begin{array}{c}\text { Barium } \\
\text { ( } \mu \mathrm{g} / \mathrm{L})\end{array}$ & $\begin{array}{l}\text { Beryllium } \\
\quad(\mu \mathrm{g} / \mathrm{L})\end{array}$ & $\begin{array}{c}\text { Cadmium } \\
(\mu \mathrm{g} / \mathrm{L})\end{array}$ & $\begin{array}{l}\text { Chromium } \\
\quad(\mu \mathrm{g} / \mathrm{L})\end{array}$ & $\begin{array}{l}\text { Cobalt } \\
\text { ( } \mu \mathrm{g} / \mathrm{L})\end{array}$ & $\begin{array}{c}\text { Copper } \\
\text { ( } \mu \mathrm{g} / \mathrm{L})\end{array}$ & $\begin{array}{l}\text { Lead } \\
\text { ( } \mu \mathrm{g} / \mathrm{L})\end{array}$ & $\begin{array}{c}\text { Manga- } \\
\text { nese } \\
(\mu \mathrm{g} / \mathrm{L})\end{array}$ & $\begin{array}{c}\text { Molyb- } \\
\text { denum } \\
(\mu \mathrm{g} / \mathrm{L})\end{array}$ \\
\hline \multicolumn{11}{|c|}{ Southern Comal flow path } \\
\hline AY-68-29-610 & $<0.30$ & 35 & $<0.06$ & $<0.04$ & $<0.8$ & 0.201 & 1.9 & 1.77 & $<0.2$ & 0.6 \\
\hline \multirow[t]{2}{*}{ AY-68-29-913 } & $<.30$ & 43 & $<.06$ & $<.04$ & $<.8$ & .128 & .8 & 1.02 & $<.2$ & .7 \\
\hline & -- & -- & -- & -- & -- & -- & -- & -- & -- & -- \\
\hline AY-68-29-914 & $<.30$ & 53 & $<.06$ & $<.04$ & $<.8$ & .118 & 1.4 & 1.39 & E. 1 & .7 \\
\hline (NBU-LCRA) & $<.20$ & 50 & $<.06$ & $<.04$ & .24 & .118 & 6 & .54 & .5 & .7 \\
\hline DX-68-23-324 & $<.30$ & 51 & $<.06$ & $<.04$ & $<.8$ & .174 & .3 & $<.08$ & $<.2$ & .6 \\
\hline \multirow[t]{2}{*}{ (Comal 7) } & -- & -- & -- & -- & -- & -- & -- & -- & -- & -- \\
\hline & $<.20$ & 57 & $<.06$ & $<.04$ & .35 & .125 & 1.6 & .2 & E.1 & .7 \\
\hline DX-68-23-325 & $<.30$ & 45 & $<.06$ & $<.04$ & $<.8$ & .177 & .5 & $<.08$ & E. 2 & .8 \\
\hline (Comal-Spring Island) & $<.30$ & 45 & $<.06$ & $<.04$ & $<.8$ & .177 & .5 & $<.08$ & E. 2 & 1.4 \\
\hline \multirow[t]{2}{*}{ DX-68-23-602 } & $<.30$ & 37 & $<.06$ & E.03 & $<.8$ & .252 & 1.8 & 1.45 & $<.2$ & 6 \\
\hline & -- & -- & -- & -- & -- & -- & -- & -- & -- & -- \\
\hline \multicolumn{11}{|c|}{ Central Comal flow path } \\
\hline \multirow[t]{2}{*}{ AY-68-29-811 } & $<.30$ & 33 & $<.06$ & $<.04$ & 1.3 & .148 & 1.1 & 1.39 & $<.2$ & .7 \\
\hline & -- & -- & -- & -- & -- & -- & -- & -- & -- & -- \\
\hline \multirow[t]{2}{*}{ AY-68-30-520 } & $<.30$ & 53 & $<.06$ & $<.04$ & $<.8$ & .138 & .8 & .96 & $<.2$ & .7 \\
\hline & -- & -- & -- & -- & -- & -- & -- & -- & -- & -- \\
\hline DX-68-15-901 & $<.30$ & 34 & $<.06$ & E.03 & $<.8$ & .26 & .6 & E.07 & .2 & .5 \\
\hline \multirow[t]{2}{*}{ (Hueco A) } & -- & -- & -- & -- & -- & -- & -- & -- & -- & -- \\
\hline & $<.20$ & 33 & $<.06$ & $<.04$ & .08 & .273 & .7 & .14 & $<.2$ & 1 \\
\hline DX-68-15-913 & $<.30$ & 34 & $<.06$ & $<.04$ & $<.8$ & .26 & .7 & .35 & .4 & .5 \\
\hline (Hueco B) & -- & -- & -- & -- & -- & -- & -- & -- & -- & -- \\
\hline
\end{tabular}


Appendix 1.3. Chemical and isotope data in ground-water samples from wells and springs (by flow path) collected for this study, northeastern Bexar and southern Comal Counties, Texas, 2003-06_-Continued.

\begin{tabular}{|c|c|c|c|c|c|c|c|c|c|c|}
\hline $\begin{array}{c}\text { State well } \\
\text { number } \\
\text { (USGS name) }\end{array}$ & $\begin{array}{l}\text { Anti- } \\
\text { mony } \\
(\mu \mathrm{g} / \mathrm{L})\end{array}$ & $\begin{array}{c}\text { Barium } \\
\text { ( } \mu \mathrm{g} / \mathrm{L})\end{array}$ & $\begin{array}{l}\text { Beryllium } \\
\text { ( } \mu \mathrm{g} / \mathrm{L})\end{array}$ & $\begin{array}{c}\text { Cadmium } \\
(\mu \mathrm{g} / \mathrm{L})\end{array}$ & $\begin{array}{c}\text { Chromium } \\
\text { ( } \mu \mathrm{g} / \mathrm{L})\end{array}$ & $\begin{array}{l}\text { Cobalt } \\
(\mu \mathrm{g} / \mathrm{L})\end{array}$ & $\begin{array}{c}\text { Copper } \\
\text { ( } \mu \mathrm{g} / \mathrm{L})\end{array}$ & $\begin{array}{l}\text { Lead } \\
\text { ( } \mu \mathrm{g} / \mathrm{L})\end{array}$ & $\begin{array}{c}\text { Manga- } \\
\text { nese } \\
\text { (pg/L) }\end{array}$ & $\begin{array}{c}\text { Molyb- } \\
\text { denum } \\
(\mu \mathrm{g} / \mathrm{L})\end{array}$ \\
\hline \multirow[t]{2}{*}{ DX-68-22-810 } & $<0.30$ & 30 & $<0.06$ & 0.05 & $<0.8$ & 0.275 & 1.1 & 5.47 & 0.2 & 0.5 \\
\hline & $<.20$ & 33 & $<.06$ & .09 & .06 & .39 & 2.5 & 3.76 & 6 & E. 2 \\
\hline \multirow[t]{2}{*}{ DX-68-22-905 } & $<.30$ & 27 & $<.06$ & E.02 & $<.8$ & .196 & .4 & 1.45 & $<.2$ & .4 \\
\hline & -- & -- & -- & -- & -- & -- & -- & -- & -- & -- \\
\hline (Comal 1) & $<.20$ & 55 & $<.06$ & $<.04$ & .24 & .12 & .4 & $<.08$ & 1.1 & .7 \\
\hline DX-68-23-323 & $<.30$ & 45 & $<.06$ & $<.04$ & $<.8$ & .179 & .3 & $<.08$ & $<.2$ & .6 \\
\hline \multirow[t]{2}{*}{ (Comal 3) } & -- & -- & -- & -- & -- & -- & -- & -- & -- & -- \\
\hline & $<.20$ & 50 & .09 & $<.04$ & .27 & .113 & .5 & .32 & $<.2$ & 6 \\
\hline \multirow[t]{2}{*}{ DX-68-23-501 } & $<.30$ & 38 & $<.06$ & $<.04$ & E. 4 & .248 & 3.2 & .79 & $<.2$ & .6 \\
\hline & -- & -- & -- & -- & -- & -- & -- & -- & -- & -- \\
\hline \multirow[t]{2}{*}{ DX-68-30-111 } & $<.30$ & 37 & $<.06$ & E.02 & $<.8$ & .283 & 1.3 & .38 & 3.8 & .9 \\
\hline & -- & -- & -- & -- & -- & -- & -- & -- & -- & -- \\
\hline \multicolumn{11}{|c|}{ Northern Comal flow path } \\
\hline \multirow[t]{2}{*}{ DX-68-23-104 } & $<.30$ & 58 & $<.06$ & .07 & $<.8$ & .087 & 1.6 & 1.8 & $<.2$ & 2.7 \\
\hline & -- & -- & -- & -- & -- & -- & -- & -- & -- & -- \\
\hline \multicolumn{11}{|c|}{ Rainfall sites } \\
\hline \multirow[t]{2}{*}{ Rainfall site 3} & -- & -- & -- & -- & -- & -- & -- & -- & -- & -- \\
\hline & -- & -- & -- & -- & -- & -- & -- & -- & -- & -- \\
\hline Rainfall site 4 & -- & -- & -- & -- & -- & -- & -- & -- & -- & -- \\
\hline
\end{tabular}


Appendix 1.3. Chemical and isotope data in ground-water samples from wells and springs (by flow path) collected for this study, northeastern Bexar and southern Comal Counties, Texas, 2003-06-Continued.

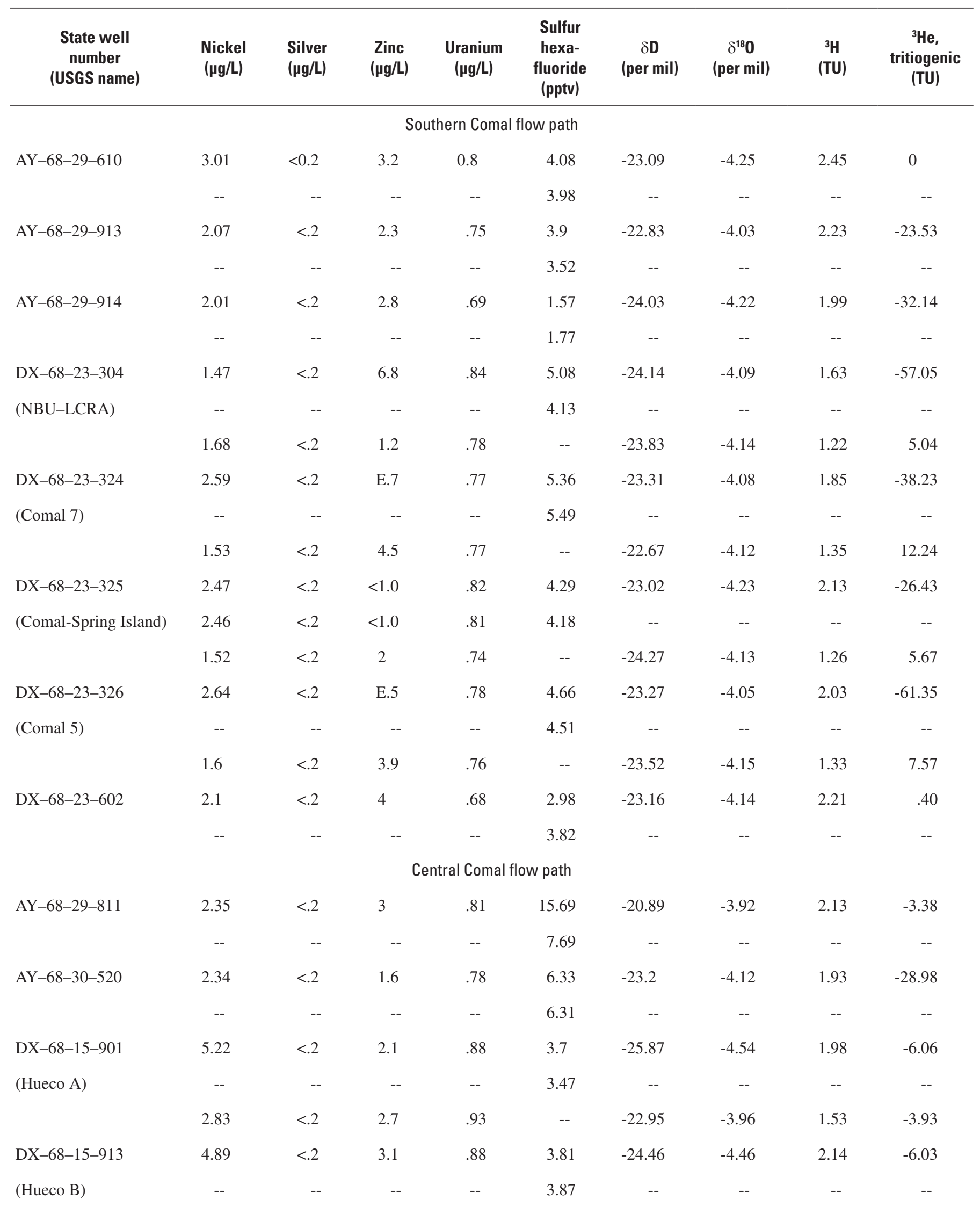


Appendix 1.3. Chemical and isotope data in ground-water samples from wells and springs (by flow path) collected for this study, northeastern Bexar and southern Comal Counties, Texas, 2003-06_Continued.

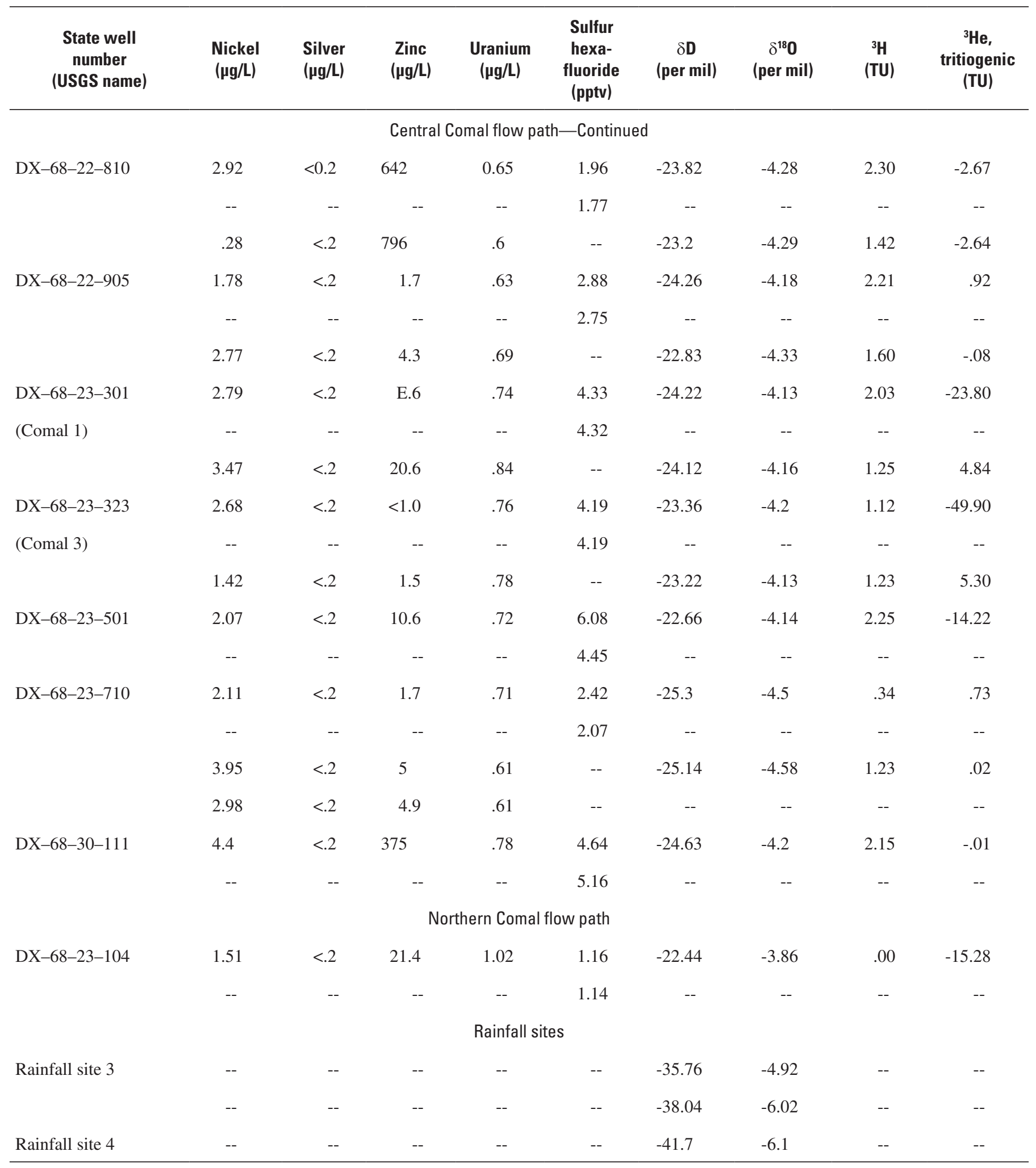


Prepared by the USGS Lafayette Publishing Service Center.

Information regarding water resources in Texas is available at http: //tx.usgs.gov/ 